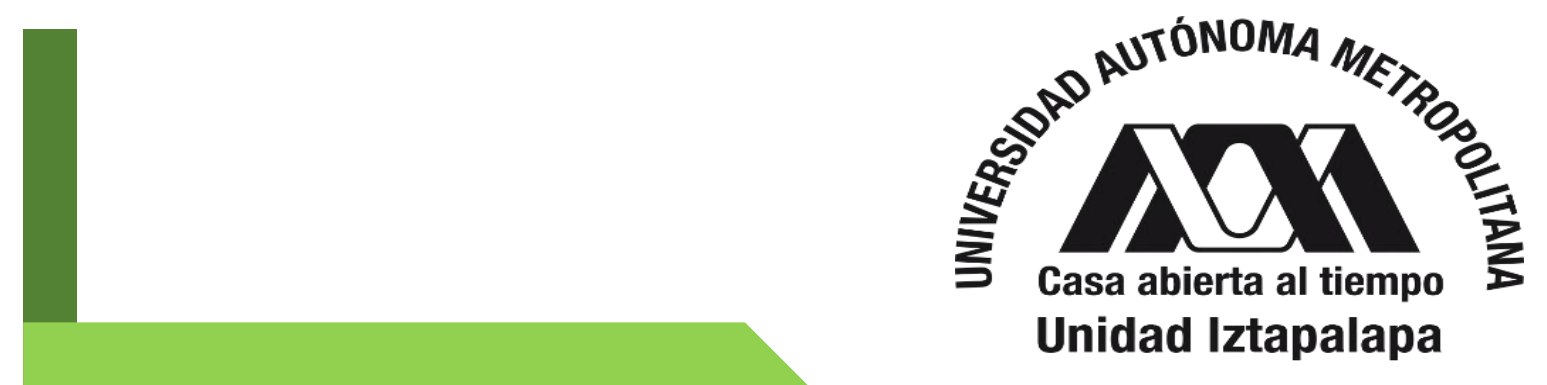

Comparación de la Actividad de la Vía de Señalización AMPc-PKA en la Producción de Lovastatina por Aspergillus terreus en Fermentación Sólida y Fermentación Líquida

\author{
T E S I S

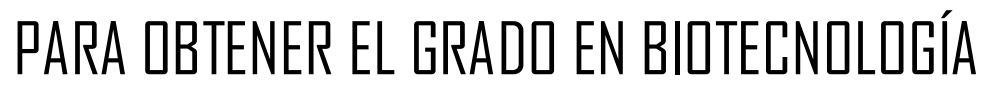 \\ PRESENTA: \\ M. en B. Teresa Pérez Aguirre
}

Director de Tesis: Dr. Javier Barrios González

Asesores: Dr. Francisco Fierro Fierro

Dr. Rafael A. Zubillaga Luna

Ciudad de México, Diciembre 2017. 
México, D.F., 14 de Diciembre del 2017.

La presente Tesis se realizó en el laboratorio de Ingeniería Genética y Metabolitos Secundarios, del Departamento de Biotecnología de la División de Ciencias Biológicas y de la Salud, en la Universidad Autonoma Metropolitana, Unidad Iztapalapa.

El Doctorado en Biotecnología de la Universidad Autónoma Metropolitana Unidad Iztapalapa, esta incluido en el Programa Nacional de Posgrados de Calidad (PNPC) del Consejo Nacional de Ciencia y Tecnología de México, con la referencia 001466.

Agradezco el apoyo recibido de la Beca a Conacyt, con el número de registro 204499, y por resguardarme estos años a la Universidad Autónoma Metropolitana (UAM - Iztapalapa) con excelentes enseñanzas. Y al laboratorio de Ingeniería Genética y Metabolitos Secundarios, por dejar grabados tantos aprendizajes y excelentes momentos de convivencia. 
Ciudad de México, a 14 de Diciembre del 2017.

El jurado designado por la

División de Ciencias Biológicas y de la Salud, Universidad Autónoma Metropolitana, Unidad Iztapalapa, aprobó la

TESIS:

\title{
Comparación de la Actividad de la Vía de Señalización AMPc-PKA en la Producción de Lovastatina por Aspergillus terreus en Fermentación Sólida y Fermentación Líquida
}

\author{
Que presentó
}

\section{M. en B. Teresa Pérez Aguirre}

Comité tutorial:

Director: Dr. Javier Barrios González

Asesores: Dr. Francisco Fierro Fierro

Dr. Rafael A. Zubillaga Luna

Jurado:

Presidente(a): Dra. Gabriela Mariana Rodríguez Serrano

Secretario: $\quad$ Dr. Armando Mejía Alvarez

Vocal: Dra. Ma. del Rosario Tarragó Castellanos

Vocal: $\quad$ Dra. Roxana Uri Miranda Labra
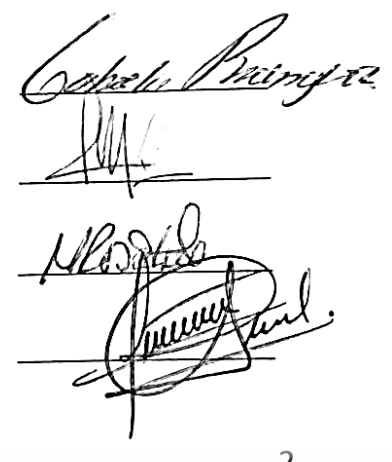


\section{DEDICATORIAS}

Agradezco infinitamente el aquí y ahora. Mi vida estos últimos años ha tenido tantas enseñanzas y tantos momentos inolvidables que me forjaron a ser una mujer madura, pero sobretodo llena de plenitud, feliz $y$ agradecida por cada segundo.

Agradezco al Creador, sin él simplemente, no existiría. Gracias Dios por esta vida con tantas pruebas, me haces cada día una mujer más fuerte y sabía. Tú me amas y siempre has estado conmigo, te amo por tantas cosas dadas....

Agradezco a ese ser que a pesar de las adversidades sigue a mi lado, mi compañero, mi amigo, mi amante, mi esposo, Armando. Gracias flaquis por enseñarme como es amar verdaderamente, como es vencer obstáculos juntos, como es vivir plenamente. Eres la mano con la que me apoyo cuando caigo, gracias por tu tiempo y perseverancia, eres sencillamente admirable. Además, existen 3 pequeños varoncitos, mis hijos Kaleb Isaí, lan Kalin e Iker Yuznier, todos ellos, son el motor de mi vida, los que nos impulsan a ir por más, a valorar cada instante, a disfrutar nuevamente nuestra infancia, pero ahora juntos, sin tapujos ni timidez. Es maravilloso lo que hemos logrado, y la mayor parte lo debo a tu gran corazón y entrega, te amo por siempre....

Agradezco a mi familia, en especial a mi madre, creo que sin su apoyo desde ingresar al Bachillerato no hubiera sido posible todo esto. Gracias madre por estar ahí, a pesar de los contras para que siguiera estudiando, por apoyarme a ser nana de mis hijos cuando lo requería, eres aún más fuerte que yo ¿sabes?, al vencer tantas limitaciones y al darme el empujón que necesitaba para ser lo que soy ahora, te amo y bendigo tu vida. Gracias padre por guiarme desde el cielo, por darme la base de la disciplina, sé que me observas y estas orgulloso de mí. A mis hermanos, porque de alguna u otra forma me han apoyado para concluir esta etapa, en especial a Estefania, Sonia y Vicky por expresarme siempre su admiración por lo que soy y he logrado, créanme que esas palabras me inspiran a ser mejor cada día. Gracias suegros por ser tan generosos y aceptarme siempre con amor 
y amabilidad, suegra Carmen agradezco sus tantas atenciones, es una mujer maravillosa y suegro Francisco, fue un pilar en esta travesía, yo creo lo inducía mi padre para estarme muele y muele con que: ¿ya mero acabas?, no dejes el Doctorado, sigue adelante, ya te falta poco, no desistas..., parte de sus palabras fueron las que me motivaron a seguir adelante, agradezco su interés y ánimo, ambos son mis segundos padres.

Agradezco a mis amistades, Roxana, Marisol y Paola, las llevo en mi corazón. Esas pláticas de vivencias, esos momentos de sincera amistad y risas, gracias por su confianza, comprensión y apoyo. A mis compañeros de laboratorio, Hypatia, Kenia, Jessy, Esmeralda, Hugo, Vicky, Octavio.... por prestarme lo necesario para avanzar y echarme la mano cuando necesitaba irme, por esos festejos, por ser parte de una estancia llevadera y divertida.

Gracias a mi director de tesis, Dr. Javier Barrios, por su asesoramiento y apoyo, sé he sido una alumna inconstante y que agrande mi familia cada nivel de posgrado, pero eso no fue desaliento en usted, agradezco su comprensión, positivismo y tiempo brindado por asesorarme de manera personal y acádemica. Igual doy gracias al Dr. Francisco José Fermádez, Francisco Fierro y Armando Mejía, que a pesar de sus tiempos límitados siempre tuvieron unos minutos para atenderme y auxiliarme en mis dudas metodológicas.

A todos que de alguna manera estuvieron conmigo, contribuyendo en mi desarrollo profesional, social y emocional, por darme alegrías y lágrimas, por recordarme que tengo la capacidad y fortaleza para enfrentar cada obstáculo, MIL GRACIAS....

\footnotetext{
"Buenas cosas vienen para aquellos que creen, cosas mejores vienen para aquellos que son pacientes, pero las más mejores cosas vienen para aquellos que no se rinden"
} 


\section{RESUMEN}

En esta tesis se estudió, el funcionamiento de la vía FadA-AMPc-PKA ligada a esporulación y al metabolismo secundario en Aspergillus terreus. Con relación a este último, se sabe que la producción de lovastatina es mayor en fermentación sólida (FS) que en fermentación líquida $(\mathrm{FL})$.

Para ello, se tomaron en cuenta algunos parámetros indicativos del funcionamiento de la vía AMPc-PKA, durante la producción de lovastatina en FS y FL. El primer nivel estudiado fue el patrón de expresión de los genes de los componentes principales: fadA (subunidad a de la proteína G), laeA (regulador global del metabolismo secundario) y sus blancos putativos corriente abajo: el factor transcripcional específico del "clúster" biosintético de lovastatina, IovE, una policétido sintasa, lov $F$, y el factor transcripcional principal de conidiación, brlA. Además, también se analizaron los genes de resistencia a estrés atfB y $m s n A$. El panorama fue complementado con los perfiles de concentración intracelular de AMPc y el perfil de la actividad PKA durante los cultivos sólido y líquido.

En el patrón de transcripción de fadA, que refleja la activación de la vía (separación y fosforilación de esta subunidad) se encontró expresión diferencial entre FS y FL, sugiriendo que estímulos ambientales en la FS son percibidos por esta vía, donde el patrón de transcripción tuvo un perfil relativamente bajo (excepto a las $21 \mathrm{~h}$ ) y más o menos constante (ligeramente más bajo en idiofase). En contraste, en $\mathrm{FL}$, fad $A$ fue alto en trofofase (18 h) y bajo desde las $21 \mathrm{~h}$ hasta idiofase. Coincidiendo con la lógica del esquema de regulación propuesto por el grupo de Nancy Keller para otras especies de Aspergillus.

Otros parámetros estudiados también indicaron un funcionamiento diferente en ambos sistemas de cultivo. Se encontraron diferencias en el perfil de concentración intracelular de AMPc y de la actividad PKA durante los distintos cultivos, ambos componentes tuvieron comportamiento similar en cada cultivo estudiado, pero opuesto a la expresión de fadA. Se esperaba una relación directa de estas dos variables con $\mathrm{fad} A$.

En FS, tanto la concentración intracelular de AMPc como la actividad PKA mostraron niveles altos en trofofase (bajando a las $21 \mathrm{~h}$ y siendo ligeramente constante en idiofase) indicando una regulación negativa en trofofase sobre lovE/lovF (probablemente a través de LaeA). Esto 
también se esperaba, de acuerdo al esquema de regulación propuesto por Keller y colaboradores. Pero, en FL, el comportamiento fue completamente opuesto, bajos en trofofase y subieron en idiofase (ligeramente subida de actividad PKA, similar que en FS), siendo controversial estos resultados. Sin embargo, la expresión de fadA, opuesto a ellos, si fue el esperado.

Por otro lado, los resultados de expresión del gen brlA también indican que la conidiación es regulada negativamente por PKA (en FS, en FL no hubo esporulación). En relación con los factores de transcripción (FTs) de respuesta a estrés, $m s n A$ mostró un patrón de transcripción en cierto modo inverso a la actividad de PKA (más expresión en idiofase). En contraste, atfB mostró una transcripción más intensa en trofofase, quizás regulada positivamente por PKA, aunque podría tener influencia de la vía SAPK MAPKinasa.

En cuanto al gen laeA, se encontró que su perfil de expresión, tanto en FL como en FS, es opuesto a la expresión de lovE y lov $F$ (y síntesis de lovastatina). Es decir, se expresa fuerte en trofofase y ligeramente en idiofase. Esto fue inesperado, por lo que el perfil de expresión parece no ser un buen indicador de la actividad de LaeA. Los resultados sugieren que la expresión de laeA está presente desde la trofofase, pero es activada por una regulación posttranscripcional o post-traduccional, en idiofase. Esto, probablemente debido a una regulación negativa por PKA, particularmente en FS.

Por otra parte, se caracterizaron transformantes que sobreexpresaron el gen laeA (SE::laeA) (bajo cualquiera de las 2 estrategias usadas: con propio promotor y con un promotor constitutivo). Los resultados demostraron que ambas estrategias fueron muy buenos métodos de mejoramiento genético molecular, sobre todo, para generar cepas sobreproductoras de lovastatina especialmente para FS, y en menos abundancia para FL. También se observó, que las mejores transformantes en FS tuvieron una mayor esporulación, confirmando a LaeA como regulador del metabolismo secundario y regulador positivo en la esporulación.

Las mejores transformantes para FS (T9laeA y T2laeAcons) y para FL (T1laeA y T5laeAcons) mostraron una extensión o prolongación de su etapa de producción, siendo esto un factor importante en el incremento de la producción. En FS, la transformante con promotor constitutivo, T2laeAcons, alcanzó $30.6 \mathrm{mg}$ de lovastatina por gss (104\% de incremento). En $\mathrm{FL}$, la transformante con promotor propio, T1 laeA, produjo $0.89 \mathrm{mg} / \mathrm{mL} 102 \%$ de incremento). 


\section{ABSTRACT}

In this thesis was studied the functioning of the FadA-AMPc-PKA pathway linked to sporulation and the secondary metabolism of Aspergillus terreus.

For this, some parameters indicative of the functioning of the c'AMP-PKA pathway were taken into account, during the production of lovastatin in in solid-state fermentation (SSF) and submerged fermentation (SmF). The first level studied was the expression pattern of the genes of the main components: fadA ( $\alpha$ subunit of the $\mathrm{G}$ protein), laeA (global regulator of secondary metabolism) and its putative downstream targets: the specific transcriptional factor of the clúster biosynthetic of lovastatin, lovE, a polyketide synthase, lov $F$, and the main transcription factor of conidiation, $b r l A$. In addition, the stress resistance genes atfB and $m s n A$ were also analyzed. The panorama was complemented with the profiles of intracellular concentration of c'AMP and the profile of PKA activity during SFF and SmF.

In the transcription pattern of $\mathrm{fad} A$, which perhaps reflects the activation of the pathway (separation and phosphorylation of this subunit), differential expression between SFF and SmF was found, suggesting that environmental stimuli in FS are perceived through this signaling pathway. In SFF, had a relatively low expression profile (except at $21 \mathrm{~h}$ ) and more or less constant (slightly lower in idiofase). In contrast, in SmF, fadA was high in trophophase (18 $\mathrm{h}$ ) and low from $21 \mathrm{~h}$ until idiofase. This expression profile of fadA was opposite to the c'AMP concentration pattern and with the PKA activity pattern in both culture systems. A direct relation of these two variables with fadA was expected, however, similarity was only found between the profiles of c'AMP and PKA. In SSF, both the intracellular concentration of c'AMP and the PKA activity showed high levels in trophophase, decreasing at $21 \mathrm{~h}$ and being slightly constant in idiofase, indicating a negative regulation on lovE/lovF (probably through LaeA). However, in SmF, a completly opposite behavior was observed: low in trophophase and increased in idiofase (slightly increased PKA activity, similar to the level in SSF), these results being controversial.

On the other hand, the expression results of the $b r l A$ gene also indicate that the conidiation is negatively regulated by PKA (in SSF, in SmF there was no sporulation). In relation to the transcription factors (FT's) of stress response, $m s n A$ showed a transcription pattern somewhat inverse to the activity of PKA (more expression in idiofase). In contrast, atfB showed a more 
intense transcription in trophophase, perhaps regulated positively by PKA, although it could have influence of the SAPK MAPKinase pathway.

As for the laeA gene, it was found that its expression profile, both in SSF and in SmF, is opposite to the expression of lovE and lovF (and synthesis of lovastatin). That is, it is expressed strongly in trophophase and slightly in idiofase. This was unexpected, so the expression profile does not seem to be a good indicator of LaeA activity. The results suggest that the expression of laeA is present from the trophophase, but is activated by a post-transcriptional or posttranslational regulation, in idiofase. This, probably due to a negative regulation by PKA, particularly in SSF.

On the other hand, transformants that overexpressed the laeA gene (SE::laeA) were characterized (under any of the 2 strategies used: with own promoter and with a constitutive promoter). The results showed that both strategies were very good methods of molecular genetic improvement, especially for SSF. In SE::/aeA overproducing strains of lovastatin were generated especially for SSF, and in less abundance for SmF. A greater sporulation was also observed in SSF, confirming LaeA as a regulator of secondary metabolism and a positive regulator in sporulation.

The best transformants for SSF (T9laeA and T2laeAcons) and for SmF (T1laeA and T5laeAcons) showed an extension or prolongation of their production stage, this being an important factor in the increase of production. In SSF, the transformant with constitutive promoter, T2laeAcons, produced $30.6 \mathrm{mg}$ of lovastatin/gss (104\% increase). In SmF, the transformant with its own promoter, T1laeA, produced $0.89 \mathrm{mg} / \mathrm{mL}$ (102\% increase). 


\section{Contenido}

$\begin{array}{ll}\text { INTRODUCCIÓN } & 14\end{array}$

VÍA DE SEÑALIZACIÓN AMPc-PKA $\quad 14$

METABOLISMO SECUNDARIO Y MEDIOS DE CULTIVO

Lovastatina $\quad 23$

REGULACIÓN GENÉTICA $\quad 25$

Regulador global laeA $\quad 26$

Complejo Velvet $\quad 28$

Otros reguladores específicos importantes

AtfB 31

$\begin{array}{ll}\text { MsnA } & 33\end{array}$

$\begin{array}{ll}\text { CONIDIACIÓN } & 34\end{array}$

$\begin{array}{ll}\text { MEJORAMIENTO GENÉTICO } & 36\end{array}$

$\begin{array}{ll}\text { JUSTIFICACIÓN } & 37\end{array}$

$\begin{array}{lr}\text { HIPÓTESIS } & 39\end{array}$

$\begin{array}{ll}\text { OBJETIVOS } & 39\end{array}$

$\begin{array}{lr}\text { Objetivo general } & 39\end{array}$

$\begin{array}{ll}\text { Objetivo particulares } & 39\end{array}$

$\begin{array}{ll}\text { MATERIALES Y MÉTODOS } & 40\end{array}$

$\begin{array}{ll}\text { CEPA UTILIZADA } & 40\end{array}$

$\begin{array}{ll}\text { CONSTRUCCIONES UTILIZADAS } & \mathbf{4 0}\end{array}$

$\begin{array}{lr}\text { pUAMTPlaeA } & 40\end{array}$

$\begin{array}{ll}\text { pUAMTPlaeAcons } & 41\end{array}$

$\begin{array}{ll}\text { REACTIVOS } & 41\end{array}$

$\begin{array}{ll}\text { EQUIPO } & 42\end{array}$

$\begin{array}{ll}\text { MEDIOS DE CULTIVO } & 42\end{array}$

Tesis de Doctorado en Biotecnología 
Crecimiento de Aspergillus terreus $\quad 45$

$\begin{array}{lr}\text { Fermentación Sólida (FS) } & 45\end{array}$

$\begin{array}{lr}\text { Fermentación Líquida (FL) } & 45\end{array}$

CUANTIFICACIÓN DE PARÁMETROS FISIOLÓGICOS 46

Fermentación Sólida (FS) $\quad 46$

Fermentación Líquida (FL) $\quad 47$

TÉCNICAS ANALÍTICAS PARA EL ANÁLISIS DE LA ACTIVIDAD DE LA VÍA AMPc-PKA 48

Medición en la cuantificación de AMPc $\quad 48$

Cuantificación de Actividad Específica PKA $\quad 49$

Cuantificación de Proteína $\quad 51$

ANÁLISIS DE ÁCIDOS NUCLEICOS

Extracción de DNA genómico de A. terreus

Extracción de RNA $\quad 52$

Diseño de oligos para obtener fragmentos DNA

Números de acceso en el NCBI de genes analizados

Reacción en cadena DNA polimerasa (PCR)

Electroforesis en geles de agarosa DNA $\quad 56$

Purificación de fragmentos DNA $\quad 56$

Secuenciación de fragmentos DNA $\quad 57$

Transferencia, Marcaje e Hibridación de ácidos nucleicos 57

Southern Blot $\quad 58$

Northern Blot $\quad 60$

qRT - PCR (PCR tiempo real) $\quad 61$

CARACTERIZACIÓN DE TRANSFORMANTES $\quad 62$

Selección de mejores transformantes $\quad 62$

$\begin{array}{ll}\text { Análisis de parámetros fisiológicos } & 62\end{array}$

$\begin{array}{lc}\text { RESULTADOS } & 63\end{array}$

$\begin{array}{ll}\text { Análisis de parámetros fisiológicos } & \mathbf{6 3}\end{array}$

$\begin{array}{ll}\text { Producción de lovastatina en FS y FL } & 63\end{array}$

$\begin{array}{ll}\text { Estudio de componentes principales de la vía AMPc-PKA } & \mathbf{6 4}\end{array}$

Pérfiles de expresión de genes fadA, laeA y lovE $\quad 64$

Concentración de AMPc y expresión de fadA en FS y FL 66

$\begin{array}{ll}\text { Actividad específica PKA en FS y FL } & 67\end{array}$

$\begin{array}{ll}\text { Otros componentes reguladores de la vía AMPc-PKA } & 68\end{array}$

Análisis in sílico de promotores fadA, lovE y laeA 
Caracterización de transformantes con SE::laeA

Obtención de construcciones pUAMTPlaeA y pUAMTPlaeAcons 71

Selección de transformantes de A. terreus $\quad 72$

Integración de construcciones en transformantes seleccionadas $\quad 74$

Efecto de la SE::laeA sobre la producción de lovastatina en las mejores transformantes 77

Análisis de expresión de genes en parental y mejores transformantes 79

$\begin{array}{ll}\text { Extracción de RNA } & 79\end{array}$

Niveles de expresión del gen laeA en mejores transformantes 80

Expresión de otros genes en mejores transformantes que SE::laeA 81

Efecto de SE::laeA sobre la esporulación y otros parámetros relacionados con la vía AMPc-PKA 84

$\begin{array}{ll}\text { Esporulación } & 84\end{array}$

$\begin{array}{lr}\text { Crecimiento radial } & 85\end{array}$

$\begin{array}{lr}\text { Estrés oxidativo } & 86\end{array}$

$\begin{array}{ll}\text { Estrés osmótico } & 87\end{array}$

$\begin{array}{ll}\text { Morfología colonial } & 88\end{array}$

DISCUSIÓN

Producción de lovastatina en FS y FL en medio complejo 90

Estudio de componentes principales de la vía AMPc-PKA: Perfiles de expresión 92

Estudio de componentes principales de la vía AMPc-PKA: Concentración de AMPc y Actividad PKA 97

SOBRE-EXPRESIÓN DE IaeA (SE::laeA): ASPECTOS BÁSICOS Y MEJORAMIENTO GENÉTICO 102

Producción de lovastatina en FCA (preselección) 104

$\begin{array}{ll}\text { Producción en FS y en FL (Selección) } & 105\end{array}$

Sobreexpresión de laeA como método de mejoramiento genético. 106

$\begin{array}{lr}\text { Caracterización de las mejores transformantes } & 107\end{array}$

CONCLUSIONES 112

$\begin{array}{ll}\text { PERSPECTIVAS } & 114\end{array}$

BIBLIOGRAFÍA 


\section{Indice de Figuras}

Fig. 1. Vía AMPc-PKA en hongos; Park y Yu, 2012. ....................................................................17

Fig. 2. Modelo de regulación de MS propuesto por Bok y Keller (2004) modificado...........................18

Fig. 3. Ruta biosintética de lovastatina, se muestran enzimas involucradas y los genes que las

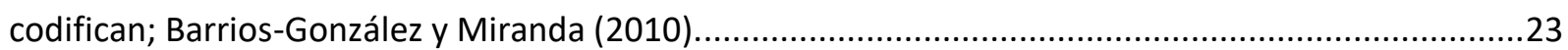

Fig. 4. Clúster de genes biosintéticos de lovastatina; Kennedy et al. (1999); Hutchinson et al. (2000). 24

Fig. 5. Modelo de la función de LaeA; Keller et al. (2005). ...............................................................28

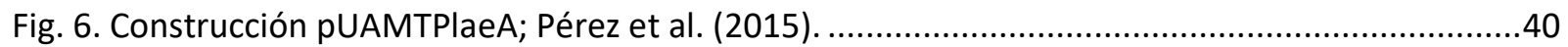

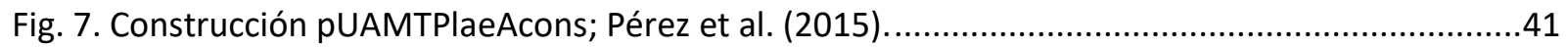

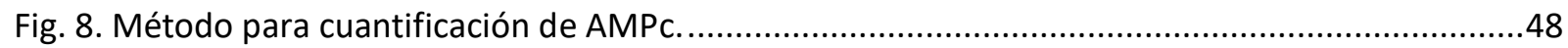

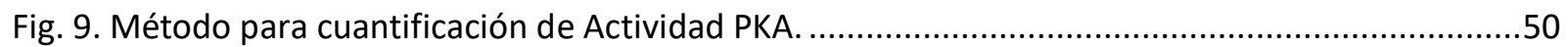

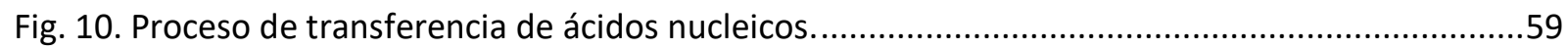

Fig. 11. Fragmento de RNA amplificado y contaminado por DNA. ................................................61

Fig. 12. Producción de lovastatina en FS (11A) y FL (11B). pH en FS (11a) y FL (11b) de parental........63

Fig. 13. Producción específica de lovastatina en FS ( \) y FL ( ๑) . ..............................................64

Fig. 14. Northern Blot y expresión absoluta de genes: $\operatorname{fad} A(\mathrm{~A})$, laeA $(\mathrm{B})$ y $\operatorname{lovE}(\mathrm{C})$ en FS ( $\mathrm{F})$..........66

y FL ( $\mathbb{1}$ ) de cepa parental. .......................................................................................................66

Fig. 15. Northern Blot y expresión absoluta de fadA en FS ( $)$ y FL ( $)$. Concentración de AMPc

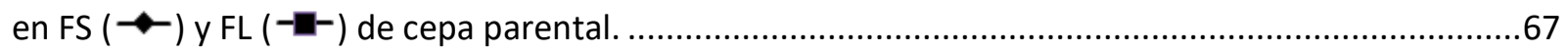

Fig. 16. Actividad específica PKA en FS ( $\square$ ) y FL (

Concentración de AMPc en FS $(-\bullet)$ y FL $(-\square-)$ de cepa parental. ..................................................68

Fig. 17. Expresión absoluta de genes: fadA, laeA, lovE, atfB, brlA, mnsA y lovF en FS ( $\square$ ) y FL ( $\mathbb{Q}$ )

de cepa parental en RT-PCR.

Fig. 18. Electroforesis para confirmar integración de construcciones en Transformantes seleccionadas:

A) pUAMTPlaeA en T1 y T9laeA, B) pUAMTPlaeAcons en T2 y T5laeAcons. .......................................75

Fig 19. Southern Blot con sonda laeA. A) Mejores transformantes con pUAMTPlaeA, B) Mejores

transformantes con pUAMTPlaeAcons.

Fig. 20. Cinética de producción de lovastatina en FS de parental ( $\rightarrow-$ ) y mejores transformantes:

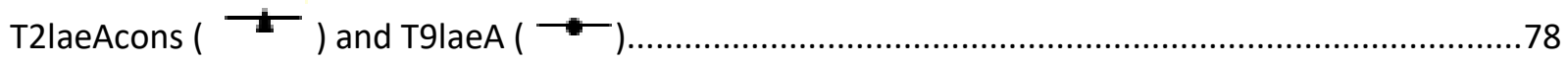

Fig. 21. Cinética de producción de lovastatina en FL de parental ( -- ) y mejores transformantes:

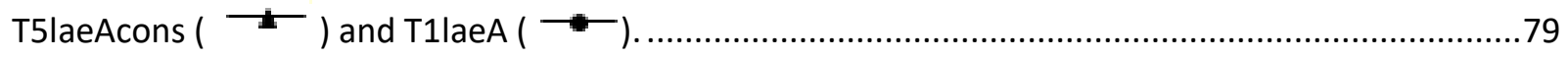

Fig. 22. Electroforesis de RNA de parental y mejores transformantes en FS y FL...............................79

Fig. 23. Expresión absoluta del gen laeA en FS de parental ( $\mathbf{a}$ ) y transformantes seleccionadas:

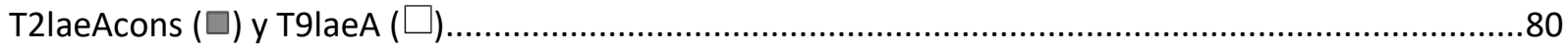

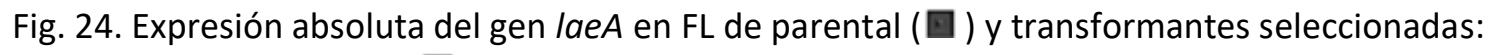

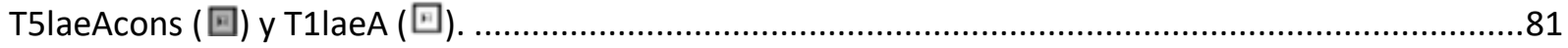

Fig. 25. Expresión absoluta de genes: fadA (A), laeA (B), lovE (C), lovF (D), brlA (E) y msnA (F). En FS de parental $(\square$ ) y mejores transformantes para FS: T2laeAcons ( $\square$ ) y T9laeA ( $\square$ ). En FL de parental ( $\square$ ) y

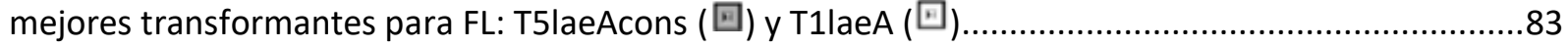

Fig. 26. Esporulación de parental ( $\square$ ), transformantes pUAMTPlaeA ( $\square$ ) y pUAMTPlaeAcons $(\square)$.....84

Tesis de Doctorado en Biotecnología 
Fig. 27. Sensibilidad a estrés osmótico. Crecimiento de parental y transformantes que SE::laeA con propio promotor, en placas PDA con $2.9 \mathrm{M} \mathrm{NaCl}$.

Fig. 28. Sensibilidad a estrés osmótico. Crecimiento de parental y transformantes que SE::laeA con promotor constitutivo, en placas PDA con $2.9 \mathrm{M} \mathrm{NaCl}$.

\section{Indice de Tablas}

Tabla 1. Diseño de oligonucleótidos $-54$

Tabla 2. Visión general de expresión de genes relacionados con la vía AMPc-PKA y concentración

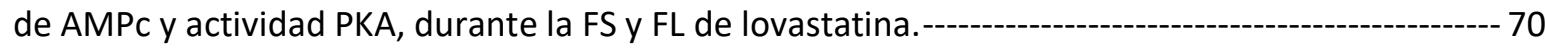

Tabla 3. Análisis in sílico de promotores fadA, lovE y laeA. -

Tabla 4. Producción de lovastatina de transformantes con construcción pUAMTPlaeA en FS y FL. Cultivo de 7 días. 73

Tabla 5. Producción de lovastatina de transformantes con construcción pUAMTPlaeAcons en FS y FL. Cultivo de 7 días. ---------------- 74

Tabla 6. Diseño de oligos para confirmar integración de construcciones en transformantes. ------ 74 Tabla 7. Análisis de enzimas de restricción para confirmar integración de construcciones por Southern Blot.

Tabla 8. Crecimiento radial e incremento en la producción de lovastatina en transformantes pUAMTPlaeAcons y pUAMTPlaeA en FS y FL. 85

Tabla 9. Incremento en crecimiento de colonias al 4to día. 86

\section{ABREVIATURAS}

MS

FS

$\mathrm{FL}$

PN

AF

ST

DNA

RNA

PCR

SE

$\mathrm{g}, \mathrm{mg}, \mu \mathrm{g}$

d, h, min

$\mathrm{mL}, \mu \mathrm{L}$

gss

$\mathrm{nm}$

$\mathrm{Ta}$
Metabolitos secundarios

Fermentación sólida

Fermentación líquida

Penicilina

Aflatoxina

Esterigmatocistina

Ácido desoxirribonucleico

Ácido ribonucleico

Reacción en cadena de la polimerasa

Sobreexpresión

gramo, miligramo, microgramo

día, hora, min

mililitro, microlitro

gramo de sustrato seco

nanometros

Temperatura ambiente 


\section{INTRODUCCIÓN}

\section{VÍA DE SEÑALIZACIÓN AMPc-PKA}

Los ascomicetos son hongos de gran importancia ya que casi el $50 \%$ de los hongos conocidos, y alrededor de $80 \%$ de los hongos patógenos humanos, están filogenéticamente relacionadas con este grupo (Guarro et al., 1999). De igual forma, muchas especies de Aspergillus poseen importancia médica $\mathrm{y} / \mathrm{o}$ industrial; por ejemplo, producen gran capacidad de enzimas hidrolíticas extracelulares, ingredientes alimentarios o producción de medicamentos (Knuf y Nielsen, 2012). Entre las especies más estudiadas dentro de este género destaca Aspergillus niger, que por un lado puede jugar un papel como un patógeno oportunista en humanos (Perfect et al., 2001), pero por otro es de gran importancia para la producción de ácido cítrico a escala industrial (Magnuson y Lasure, 2004). Aspergillus oryzae es un organismo bien conocido, "generalmente considerado como seguro" (GRAS), en la industria de la fermentación de alimentos. Aspergillus fumigatus es un patógeno humano oportunista especializado, un organismo saprófito (Van de Bossche et al., 1988; Pitt, 1994; Haines, 1995) con propagación de conidiosporas al aire (Mullins et al., 1976, 1984). Aunque A. fumigatus se considera como el hongo más peligroso, ya que causa más del $90 \%$ de aspergilosis en humanos (Kurup y Kumar, 1991; Dixon y Walsh, 1992; Schaffner, 1992; Derouin, 1994; Haines, 1995; Latgé, 1999), existen otras especies que son patógenos potenciales; por ejemplo, $A$. flavus, A. terreus y A. nidulans (Latgé, 1999).

Por otra parte, $A$. nidulans se ha usado como organismo modelo genético dentro del género Aspergillus, con una base de datos enorme (http://www.aspgd.org/) de propiedades bioquímicas y genéticas.

Aspergillus terreus produce una gama de metabolitos secundarios, como el ácido itacónico, lipasas y celulasas putativas, lovastatina (agente reductor del colesterol sérico) y toxinas citrinina, emodina y gliotoxina, así como otros compuestos, incluyendo aspulvinonas, asterriquinonas, butirolactonas y $(+)$ - geodina. $A$. terreus se ha considerado entre los patógenos fúngicos, aunque recientemente se ha sugerido que las esporas de $A$. terreus tienen un papel importante (pero diferente que las esporas de $A$. fumigatus) en la aspergilosis invasiva, por permanecer vitales en los macrófagos después de la fagocitosis, incluso en 
huéspedes inmunocompetentes. La esporulación juega un papel importante en la patogenicidad aumentando las defensas contra diversas condiciones ambientales en los hongos filamentosos (Palonen et al., 2017).

En los hongos filamentosos, la notable complejidad de las vías de señalización y de regulación ha sido reconocida por primera vez en los años 80. Desde entonces, la secuenciación de los genomas y la mejora en las herramientas de biología molecular permiten conseguir una visión más profunda en la estructura fina y la regulación de las cascadas de transducción de señales y también de las conexiones cruzadas entre estas vías. Hoy en día, el conocimiento sobre las interacciones entre las vías de señalización se va conociendo rápidamente, y la visión de que actúan de manera concertada para mantener el crecimiento, facilitar la propagación, o poner en funcionamiento programas de muerte celular está ampliamente aceptada. La vía de señalización AMPc-PKA ha demostrado jugar un papel importante en la respuesta al estrés ambiental, en particular estrés nutricional, en el organismo modelo Saccharomyces cerevisiae. Se ha propuesto como el mecanismo por el cual la célula detecta cambios en la disponibilidad de glucosa y ajusta su maquinaria metabólica en consecuencia. Para mantener la eficiencia metabólica, la presencia de glucosa en el medio estimula la vía AMPc-PKA, lo que conduce a la represión de los genes implicados en el metabolismo de fuentes de carbono alternativas a la glucosa (Thevelein, 1994).

En Aspergillus, la señalización del crecimiento vegetativo a través de la proteína G heterotrimérica $\operatorname{FadA}(\mathrm{G} \alpha):: \mathrm{SfaD}(\mathrm{G} \beta):: \mathrm{GpgA}(\mathrm{G} \gamma)$ y su regulador FlbA está también conectado firmemente con las cascadas de señalización que regulan el desarrollo asexual y sexual, autolisis, apoptosis y la producción de importantes metabolitos secundarios, incluyendo micotoxinas (esterigmatocistina -ST- y aflatoxina -AF-) y antibióticos (penicilina -PN-). Aún así, se necesitan más estudios para comprender mejor la organización y regulación de esta compleja red de señalización utilizado en el género Aspergillus (Pusztahelyi y Pócsi, 2013).

Actualmente se sabe que la cascada de señalización de la proteína G, ligada a la esporulación y el metabolismo secundario en Aspergillus spp., está centrada sobre la vía de transducción de señales proteína G/AMPc/PKA quien regula una variedad de procesos del desarrollo en hongos. Las proteínas $\mathrm{G}$ heterotriméricas acopladas a receptores transmembranales representan una importante familia de proteínas implicadas en esta señalización. La unión de 
un ligando a un receptor de la proteína G (GPCR: G Protein-Coupled Receptor) es el evento que activa la señalización de la proteína $G$. Los receptores GPCR residen en la membrana celular, donde percibe señales extracelulares tales como luz, iones, aminoácidos, azúcares, ácidos nucleicos, esteroides, polipéptidos y ácidos grasos, y transmiten esta señal al interior de la célula, activando a las proteínas $G$ heterométricas. Los hongos filamentosos comúnmente poseen tres subunidades de las proteínas $\mathrm{G}$ heterotriméricas: la $\alpha$, la $\beta$ y la $\gamma$ (Bölker, 1998). El genoma de A. nidulans contiene 3 subunidades Ga: FadA (Yu et al., 1996b), GanA (Chang et al., 2004; Han et al., 2004b) y GanB (Chang et al., 2004). El crecimiento de A. nidulans se regula a través de la vía de transducción de señales dependiente de FadA, donde FadA es parte de una proteína $G$ heterotrimérica $[\operatorname{FadA}(G \alpha):: \operatorname{SfaD}(G \beta):: G \operatorname{GgA}(\mathrm{G} \gamma)]$ (Seo et al., 2005; Yu, 2006). Todas las proteínas $G$ heterotriméricas, que están funcionalmente bien conservadas en el género Aspergillus, tienen un papel central en las respuestas fisiológicas y bioquímicas a varios estresores externos, controlan la síntesis de AMPc (adenosín monofosfato-3',5' cíclico) por la adenilato ciclasa, y su degradación por fosfodiesterasa (convierte el AMPc en AMP, y por lo tanto, se desactiva la proteína quinasa A (PKA) al disminuir la concentración de AMPc). Tras la activación del receptor acoplado a proteína G, se activa el adenilato ciclasa que cataliza la conversión de ATP a AMPc, que se acumula en la célula, lo que lleva a la activación de PKA (Lengeler et al., 2000). Cuando FadA está en un estado de unión a GTP activo y el heterotrímero se ha disociado en FadA-GTP y dímero SfaD::GpgA, activan una serie de efectores corriente abajo e inician y mantienen el crecimiento vegetativo (Rosén, 1999; Seo et al., 2005; Yu, 2006) en parte a través de la PKA dependiente de AMPc. En su forma inactiva, PKA comprende una holoenzima de 2 subunidades catalíticas y 2 regulatorias. Cuando el AMPc se une a las subunidades reguladoras, PKA se activa, lo que provoca un cambio conformacional que libera las subunidades catalíticas al autofosforilarse entre sí y fosforilar numerosos sustratos con residuos en serina o treonina que se presentan en un contexto de secuencia de Arg-Arg-Xaa-Ser/Thr o Lys-Arg-Xaa-Xaa-Ser/Thr dando lugar a la respuesta celular, tal como se muestra en la Figura 1 (Walsh y Van Patten, 1994; Shimizu y Keller, 2001; Park y Yu, 2012). 


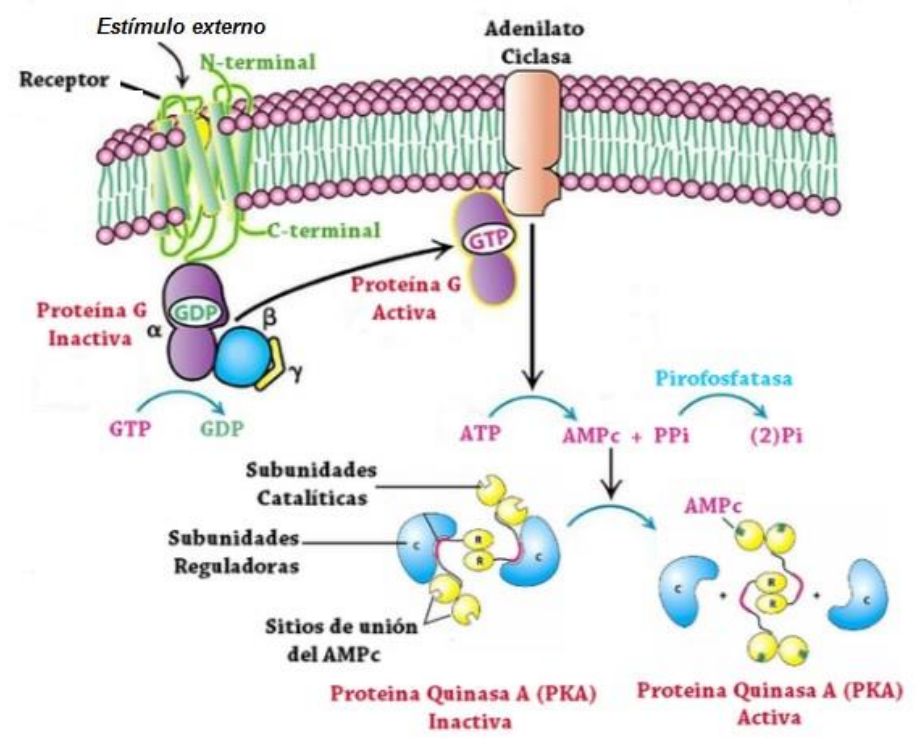

Fig. 1. Vía AMPc-PKA en hongos; Park y Yu, 2012.

Varios mecanismos de regulación trabajan para asegurar que los niveles de AMPc y la actividad quinasa estén estrechamente controladas. El adenilato ciclasa y la actividad de la fosfodiesterasa determinan los niveles totales de AMPc, y factores adicionales de acceso a AMPc son responsables de regresar a la proteína quinasa al estado inactivo. Varias isoformas de subunidades de PKA codificados por genes distintos han sido identificadas en eucariontes superiores (Døskeland et al., 1993). PKA modula la función de factores nucleares que se unen a secuencias de ADN en las regiones promotoras de genes inducibles por AMPc (Lalli y Sassone-Corsi, 1994). En hongos, PKA parece estar involucrado en el control de la actividad de un gran número de enzimas. La investigación más detallada sobre la función de PKA en vías de transducción de señales se ha llevado a cabo con $S$. cerevisiae, donde la actividad PKA es esencial para el crecimiento, progresión del ciclo celular, esporulación y sensibilidad a varias formas de estrés (Toda et al., 1987b; Thevelein, 1994).

La capacidad de los organismos para responder a estímulos extracelulares es esencial para la supervivencia. La vía de señalización AMPc-PKA ha demostrado ser crítica en la detección de los cambios ambientales y la traducción de esos cambios en una respuesta biológica en muchos organismos (Thevelein, 1994). La entrada de la subunidad C activa de PKA en el núcleo de la célula y la posterior fosforilación de factores transcripciones constituyen la base de la regulación transcripcional PKA, dando lugar a la respuesta celular, mientras que regula negativamente el desarrollo sexual/asexual y la producción de esterigmatocistina (ST) en $A$. 
nidulans (Keller et al., 2005; Pusztahelyi y Pócsi, 2013) y de numerosos metabolitos secundarios en varias especies de hongos. En la Figura 2, se muestra el modelo propuesto por Bok y Keller (2004) para la regulación del crecimiento, esporulación y metabolismo secundario en Aspergillus sp., las flechas indican efectos positivos y las barras efectos negativos.
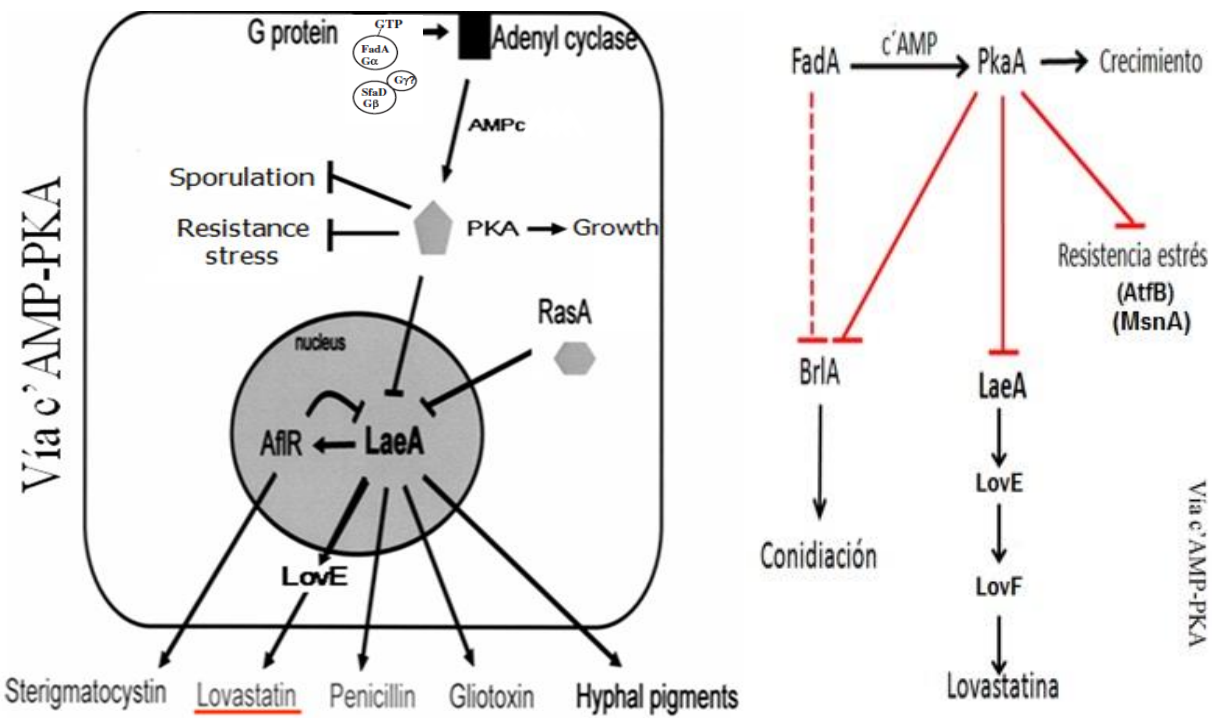

Fig. 2. Modelo de regulación de MS propuesto por Bok y Keller (2004) modificado.

Como se muestra en Figura 2, el proceso de esporulación, resistencia a estrés y producción de metabolitos secundarios parten de elementos regulatorios comunes, como las rutas de transducción de señales de las proteínas $G$ heterotriméricas. En Aspergillus spp., se ha demostrado que la esporulación y la producción de micotoxinas son regulados conjuntamente por miembros de la ruta de señalización G/AMPc/PKA (proteína G/ AMP cíclico/ proteína quinasa A) (Hicks et al., 1997; Shimizu y Keller, 2001). La activación del desarrollo requiere que la señalización de FadA esté al menos parcialmente inactivada y esto requiere del producto de otro gen, denominado flbA (Lee y Adams, 1994b). La proteína FlbA tiene una región C-terminal de 120 aminoácidos denominada dominio RGS (Regulador de señalización de la proteína G) compuesta por una familia de proteínas encontradas en organismos que van desde la levadura hasta el humano, que aparentemente activan la actividad GTPasa intrínseca de las subunidades a específicas de la proteína G heterotrimérica regulando negativamente la vía de señalización mediada por la proteína G (Berman et al., 1996). Mediante la estimulación de la hidrólisis de GTP, aumentando 
significativamente la actividad FadA-GTPasa, FadA-GTP se convierte rápidamente en FadAGDP, su forma inactiva (Yu et al., 1996), bloqueando la señalización de la proteína G, disminuyendo el crecimiento del micelio (Rosén, 1999; Seo et al., 2005; Yu, 2006) y desencadenando el desarrollo asexual de conidióforos (Yu et al., 1996; Park y Yu, 2012) y la síntesis de ST.

Shimizu y Keller (2001) publicaron evidencia genética de que la regulación FadA/FlbA en la síntesis de ST y conidiación está mediada por proteína quinasa dependiente de AMPc (PKA) en $A$. nidulans. En la sobreexpresión de pkaA (gen que codifica la subunidad catalítica de PKA) no fueron detectados los transcritos de dos genes implicados en la síntesis de ST (stcU y aflR), reduciendo a niveles por debajo de la cepa parental la acumulación de ST y la conidiación. Por otro lado, la supresión de pkaA aumentó la conidiación e inhibió el crecimiento. Mientras que la supresión de pkaA en una cepa con alelo fad $A$ activado ( $f a d A^{G 42 R}$ ), es decir, con una expresión constitutiva del gen fadA, restauró la conidiación, pero no la síntesis de ST. Por ello, los autores sugieren que FadA regula positivamente PKA y a su vez, regula negativamente la expresión de aflR y la conidiación. Además, Roze et al. (2004) encontraron en una mutante con alelo $f a d A^{G 42 R}$ en TJYP1-22, un aumento moderado (2 veces) de AMPc intracelular fisiológico y una alta actividad PKA basal (fracción de PKA activada por AMPc endógeno in vitro) y total, no teniendo capacidad para responder a pulsos de AMPc de estímulos externos, apagando permanentemente la conidiación y síntesis AF. Por estas razones, sugirieron que FadA regula positivamente la actividad PKA mediante la estimulación de un aumento fisiológico en la concentración de AMPc intracelular y propusieron que existe un circuito regulador de compensación independiente de FadA sobre el metabolismo secundario (por arriba de la activación directa de la subunidad reguladora PKA mediante la unión de AMPc). Esta propuesta es apoyada por una investigación realizada por Fillinger et al. (2002), en una mutante supresora $p k a A$ de $A$. nidulans donde se elevó 250 veces el AMPc intracelular, disminuyendo la síntesis de AF y conidiación, concluyendo que FadA/PKA regulan la síntesis de la toxina y conidiación a través de mecanismos similares en Aspergillus spp., y que los niveles de AMPc intracelular, al menos en parte, median una influencia reguladora dependiente de PKA sobre la conidiación y síntesis de AF en A. parasiticus. Además, PkaA fue descrita como un regulador de los genes fluG y fadA y en el desarrollo de conidióforos (Shimizu y Keller, 2001; Shimizu et al., 2003). 


\section{METABOLISMO SECUNDARIO Y MEDIOS DE CULTIVO}

Los metabolitos secundarios (MS) microbianos, son compuestos con estructuras químicas variadas y sofisticadas, como la penicilina (PN), cefalosporina, ergotato y estatinas, producidos principalmente por hongos y actinomicetos. Aunque los antibióticos son los MS mejor conocidos, hay otros con una enorme gama de actividades biológicas, como compuestos con actividades antiinflamatorias, hipotensivas, antitumorales, anti-colesterolémicas, y también otros usados como insecticidas, reguladores del crecimiento en plantas, herbicidas y pesticidas amigables con el ambiente, entre otros (Barrios-González et al., 2003; Keller et al., 2005).

Una característica del metabolismo secundario es que los compuestos no son producidos durante la fase de crecimiento rápido (trofofase), sino que se sintetizan durante una fase de producción subsecuente (idiofase), cuando el crecimiento se limita por el agotamiento de uno de los nutrientes esenciales, por ejemplo, carbono, nitrógeno o fuentes de fosfato (BarriosGonzález y Mejía, 1996).

Los MS son compuestos bioactivos de bajo peso molecular y provienen de un número limitado de precursores del metabolismo primario, por lo que son producidos en rutas biosintéticas comunes correlacionadas con un estado específico de diferenciación morfológica (Bok et al., 2006). Algunos MS (incluyendo los antibióticos) estimulan la formación de esporas y la inhibición o estimulación de la germinación. Así, el metabolito secundario puede retrasar la germinación de esporas hasta encontrarse en un ambiente de menor competitividad y mejores condiciones para el crecimiento, proteger el estado latente o la iniciación de las esporas o limpiar el ambiente de microorganismos competidores durante la germinación (Demain y Fang, 2000).

Respecto a los sistemas de cultivo empleados para producir infinidad de compuestos, se sabe que la evolución de los hongos superiores y actinomicetos se llevó a cabo en sustratos de crecimiento sólido. En otras palabras, estos organismos pasaron su historia evolutiva como terrestres. Productos fúngicos de interés biotecnológico (por ejemplo, enzimas, MS y esporas) se producen por estos organismos en sustratos sólidos húmedos, pero no en líquidos. En consecuencia, el cultivo de microorganismos en fermentación líquida ( $F L)$ puede deteriorar sus eficiencias metabólicas (Barrios-González, 2012). La fermentación sólida (FS) es un método 
de cultivo antiguo que ha ganado atención en los últimos 20 años, y credibilidad entre muchas empresas industriales.

La FS se considera una tecnología emergente con gran potencial para producir enzimas y metabolitos microbianos. Los investigadores han mostrado un gran interés en este tipo de fermentación, como una alternativa potencial a la FL, debido a la utilización de sustratos económicos, poco procesamiento, requerimientos de energía bajos, fácil monitoreo y control de parámetros, no hay limitaciones de transferencia de oxígeno, altos rendimientos en tiempos cortos, generación de pocos efluentes y no se requieren condiciones estériles estrictas. En la actualidad, esta tecnología es aplicada para la producción de MS (Robinson et al., 2001; Barrios-González et al., 2003). La fermentación sólida (FS) se define como el cultivo de microorganismos sobre la superficie e interior de una matriz sólida, con bajos niveles de actividad de agua. Se distinguen dos tipos de sistemas de FS dependiendo de la naturaleza de la fase sólida; cultivo sólido sobre soportes naturales y cultivo sobre soportes inertes impregnados con medio líquido (Barrios-González y Mejía, 1996).

Hace poco, se desarrolló un proceso de producción de lovastatina por FS sobre un soporte inerte artificial (espuma de poliuretano) que no sólo facilita estudios básicos, sino que también induce a una enorme productividad (Baños et al., 2009). Por otra parte, la FS sobre soportes inertes puede superar las desventajas de los soportes naturales, mejorando el control de transferencia de calor y masa. El soporte sirve de reservorio de nutrientes y como anclaje para los microorganismos. Otras ventajas, es que la recuperación de productos es menos complicada y son obtenidos con menos impurezas, la composición del medio puede ser diseñado con precisión y puede extraerse el medio líquido del soporte inerte en cualquier tiempo del cultivo y analizar sus componentes (Barrios-González y Mejía, 1996; Ooijkaas et al., 2000). La FS usando un soporte polimérico absorbente inerte capaz de absorber abundante medio líquido conduce al incremento en el área superficial disponible para el crecimiento fúngico y la tendencia del microorganismo a adherirse a la superficie del soporte, resultando en un incremento de la producción de MS, debido posiblemente a que, los microorganismos imitan su hábitat de crecimiento natural silvestre. Además, algunas características del soporte pueden cambiar significativamente durante las etapas de crecimiento del hongo y pueden generar gradientes de condiciones ambientales que producen limitaciones nutrimentales simulando la variabilidad encontrada en la naturaleza (Ramunas et 
al., 2006). De igual manera, las características fisicoquímicas del soporte y su interacción con la disponibilidad de agua, oxígeno y los componentes del medio son variables principales que pueden influir en el crecimiento y metabolismo, mientras que otros factores pueden jugar un papel sobre la colonización de microorganismos en el soporte (Gervais et al., 1988; Verstrepen et al., 2004).

A pesar de las ventajas observadas en la FS, en comparación a la FL convencional, tal vez el inconveniente más grave de $\mathrm{FS}$, en relación con la FL, es el poco conocimiento de la fisiología de hongos y otros microorganismos cultivados en FS (Barrios-González, 2012). Uno de los principales aspectos positivos de la FS es que las enzimas y metabolitos secundarios, son, en muchos casos, producidos con rendimientos mucho más altos que en FL (Barrios-González et al., 1988; Barrios-González et al, 1993; Balakrishnan y Pandey, 1996; Robinson et al, 2001; Barrios-González y Mejía, 2007). Se considera que esto es parte de la fisiología particular mostrada por los hongos en FS, frecuentemente llamado fisiología de medio sólido (BarriosGonzález, 2012).

Por otra parte, a través del tiempo se ha observado que la biosíntesis de MS por lo general está asociada con la diferenciación morfológica, tal como la esporulación, y en efecto dicha relación sugiere procesos independientes regulados por un mecanismo común (Betina, 1995). La esporulación exhibida por diversos hongos filamentosos, especialmente especies de Aspergillus, es estimulada principalmente por la exposición de hifas al aire (Morton, 1961; Ramunas et al., 2006). Así la fermentación sólida que involucra un soporte polimérico es conveniente para la inducción de patrones de diferenciación celular en hongos, y la asociación de estímulos adicionales como los efectos de superficie, desecación, estrés osmótico y limitación de nutrientes, influyendo en los procesos de desarrollo capaz de alterar el crecimiento y fisiología, así como la producción de MS, como la lovastatina en A. terreus (Morton, 1961; Barrios-González y Mejía, 1996; Larroche, 1996). 


\section{Lovastatina}

La lovastatina es un metabolito secundario con gran valor comercial producido por Aspergillus terreus y Monascus purpureus, el primero utilizado para producción industrial. Este compuesto, así como su derivado inmediato, la simvastatina, baja los niveles de colesterol en sangre (Endo, 2004; Barrios-González y Miranda, 2010).

Estudios por resonancia magnética y espectroscopia de masas provenientes de la clonación y la caracterización parcial del clúster de genes biosintéticos de lovastatina en $A$. terreus han analizado la ruta biosintética de la lovastatina. Los autores obtuvieron que la lovastatina está compuesta de dos cadenas de policétidos distintos unidas a través de un enlace éster, las cuales son ensambladas por 2 policétidos sintasas (Sistema Multifuncional de Policétido Sintasas (PKSs) el cual comprende una Nonacetido Sintasa (LNKS) involucrada en la ciclación de la cadena principal de policétidos, para formar el sistema de anillos de hexahidronaftaleno, y Dicetido Sintasa (LDKS) involucrada en la transferencia del metilbutiril al costado de la cadena de la monacolin J (Chan et al., 1983; Moore et al., 1985; Yoshizawa et al., 1994; Hendrickson et al., 1999; Kennedy et al., 1999 y Manzoni y Rollini, 2002) (Figura 3).

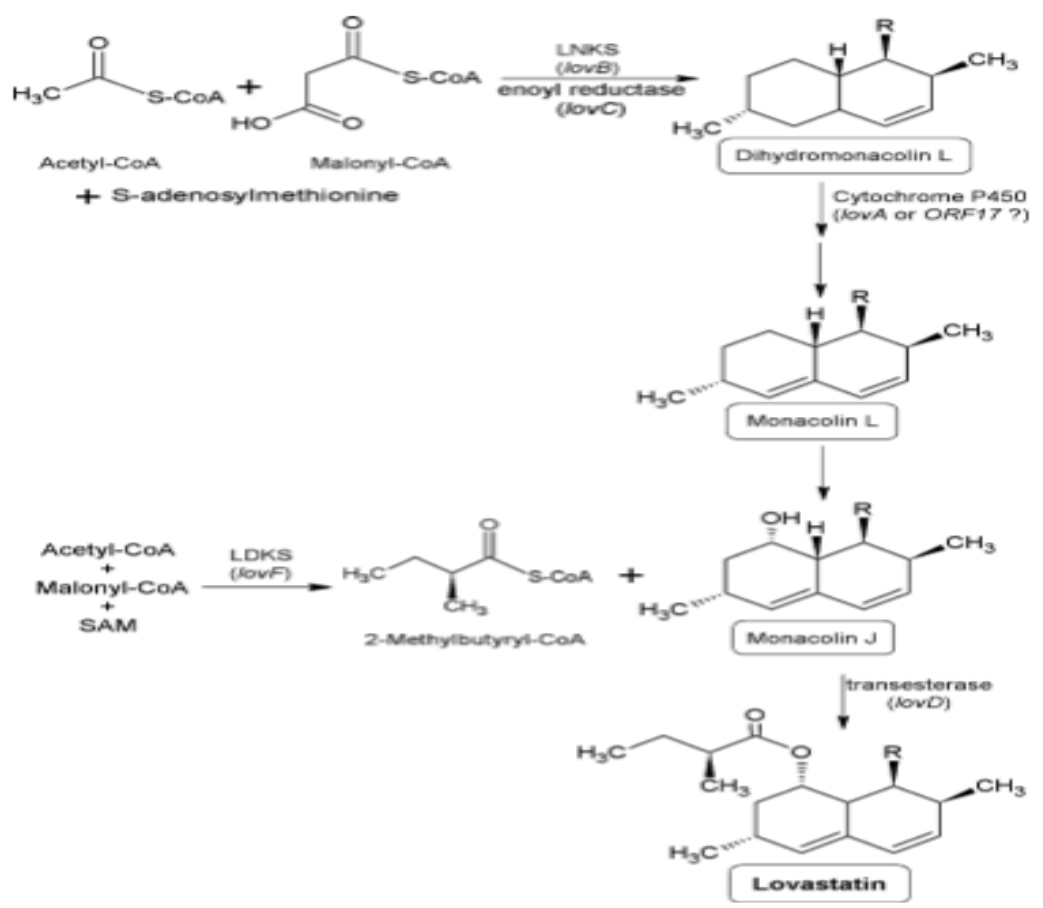

Fig. 3. Ruta biosintética de lovastatina, se muestran enzimas involucradas y los genes que las codifican; Barrios-González y Miranda (2010). 
El clúster de genes biosintéticos de lovastatina consiste en 18 probables marcos de lectura abiertos (open reading frames u ORFs): lovB y lovF biosíntesis de policétidos; lovC enoil reductasa; lovD transesterasa; lovE y lovH genes reguladores; ORF2 Y ORF17 genes de citocromos P-450; ORF1 y ORF10 genes potenciales de resistencia; ORF12 y ORF16 genes de transporte; lovG, ORF12, ORF15 y ORF18 función desconocida (Kennedy et al., 1999; Hutchinson et al., 2000) (Figura 4).

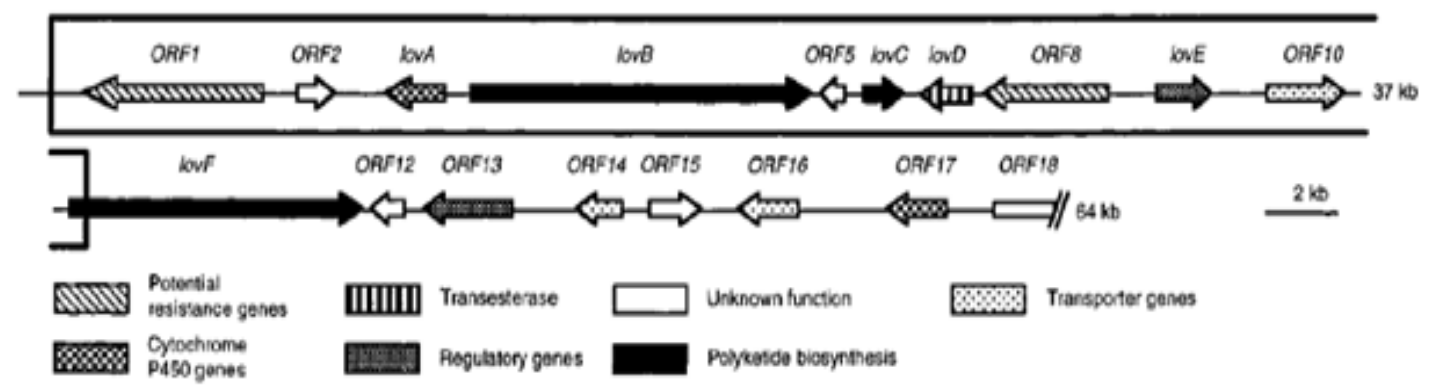

Fig. 4. Clúster de genes biosintéticos de lovastatina; Kennedy et al. (1999); Hutchinson et al. (2000).

Respecto a la producción industrial de lovastatina, está se realiza convencionalmente con cepas de $A$. terreus en FL. Sin embargo, la FS se ha convertido en un sistema de producción industrial alternativo (Suryanarayan, 2003). Se demostró que los mismos medios utilizados para FL se podrían utilizar con éxito en FS, usando una concentración más alta. El medio concentrado $2 X$ causó un aumento de 5 veces en la producción de lovastatina. También altos contenidos de humedad iniciales inducían mayores rendimientos del metabolito (BarriosGonzález et al., 1988).

Por otra parte, estudios moleculares realizados por Barrios-González y colaboradores (2008) han encontrado discrepancias en la expresión génica de $A$. terreus, en la producción de lovastatina en FS y FL, específicamente en el análisis de expresión de 2 genes, lovE y lovF, involucrados en la biosíntesis de lovastatina. El gen lovE, codifica un factor transcripcional (FT) específico que regula la expresión de todos los genes que participan en esta vía biosintética (clúster), mientras que el gen lov $F$ codifica una policétido sintasa involucrada en la biosíntesis de lovastatina. Sus resultados muestran que diferencias en producción de lovastatina entre ambos sistemas de cultivo se debe a una expresión diferencial de genes involucrados en la producción de lovastatina. La producción de lovastatina más alta en FS 
está relacionada con niveles más altos de acumulación de los transcritos lovE y lov $F$ por un periodo más largo, comparados con la FL. Los autores propusieron que niveles altos de transcripción de un FT (lovE), es una importante causa subyacente de la mayor producción reportada de metabolitos secundarios en FS en otros microorganismos (Barrios-González y Mejía, 2007; Barrios-González et al., 2008). Esto indica que hay ciertas señales ambientales que notifican al hongo que está en medio sólido, estos estímulos son detectados y transducidos, lo que provoca una serie de eventos a nivel molecular. Estas reacciones regulan positivamente FT's que regulan a su vez diferentes grupos de genes (específicamente LovE y el clúster biosintético de lovastatina en $A$. terreus) mientras que regulan negativamente otros grupos de genes, en conjunto dando lugar a la fisiología del medio sólido, mayor producción de MS (lovastatina) y otras características de crecimiento en la FS (Barrios-González, 2012).

\section{REGULACIÓN GENÉTICA}

Evidencias encontradas por Misiek y Hoffmeister (2007), señalan que los genes para la biosíntesis y regulación de MS en hongos (por ejemplo, antibióticos, fitotoxinas, micotoxinas, y productos farmacéuticos) se dio evolutivamente de manera conjunta, ya que al estar agrupados sus genes en un sitio cromosomal (clúster), incrementa la probabilidad de comovilización y aporta ventajas selectivas al propio clúster, el cual abarca genes biosintéticos y para autorresistencia, regulación y transporte (Zhang et al., 2004; Yu y Keller, 2005). La ST y AF son micotoxinas producidas por $A$. nidulans y son los MS más tóxicos, mutagénicos y cancerígenos conocidos (Sweeney y Dobson, 1999; Yu y Keller, 2005). El regulador clave de la biosíntesis ST/AF es AfIR, un factor de transcripción de tipo $\mathrm{Zn}(\mathrm{II})_{2} \mathrm{Cys}_{6}$, específico para los genes del clúster (Yu et al., 1996). La expresión de aflR está relacionado con el desarrollo de conidióforos a través de regulaciones transcripcional y post-transcripcional por la vía de señalización $\operatorname{FadA}(\mathrm{G \alpha}):: \operatorname{SfaD}(\mathrm{G} \beta):: G p g A(G y)$-proteína G-AMPc-proteína quinasa $A$ (Hicks et al., 1997; Shimizu et al., 2003; Brodhagen y Keller, 2006; Tag et al., 2000; Roze et al., 2004).

La regulación del clúster de genes que codifican para la síntesis de MS es explicada, en parte, por el control transcripcional coordinado de los genes biosintéticos mediante factores de transcripción de dominio "estrecho" ó "amplio" en hongos. Los genes de los reguladores específicos de dominio estrecho se encuentran localizados normalmente en el clúster y 
regulan positivamente la expresión de genes. Estos son frecuentemente proteínas binucleares con dedos de zinc $\mathrm{Zn}(\mathrm{II})_{2} \mathrm{Cys}_{6}$, que se han identificado únicamente en hongos. Una proteína de este grupo es AfIR (regulador de AF), la proteína $\mathrm{Zn}(\mathrm{II})_{2} \mathrm{Cys}_{6}$ que es requerida para activar los genes biosintéticos de AF y ST.

Los factores transcripcionales de dominio amplio están conservados en todos los hongos y otros eucariontes, son importantes en la respuesta celular integrada a parámetros ambientales, como fuentes de $\mathrm{C}$ y $\mathrm{N}$, temperatura, luz y $\mathrm{pH}$, frecuentemente del tipo dedo de zinc $\mathrm{Cys}_{2} \mathrm{His}_{2}$. Las respuestas a las señales ambientales son transmitidas a través de estos factores de transcripción globales que median la señalización de carbono (CreA), nitrógeno y $\mathrm{pH}(\mathrm{PacC})$, etc., y pueden regular positiva o negativamente. La regulación de factores de transcripción de dominio estrecho o amplio asegura que las rutas de los metabolitos secundarios puedan responder a la demanda de un metabolismo celular general y la presencia de inductores específicos de ruta (Keller et al., 2005).

\section{Regulador global laeA}

Recientemente se identificó un regulador global para la síntesis de metabolitos secundarios en Aspergillus spp., llamado laeA. Este gen se identificó a través de la complementación de una mutante de $A$. nidulans con esporulación normal, pero con incapacidad para expresar el gen afIR, que codifica el factor específico AfIR que regula la expresión de genes biosintéticos de ST. LaeA es una proteína altamente conservada en hongos filamentosos y un factor de virulencia conservado en todos los hongos patógenos examinados hasta la fecha.

LaeA posee una gran especificidad para familias enteras de clústers de genes de MS, ya que se demostró que es requerida para la biosíntesis de ST, PN y pigmentos miceliales en A. nidulans, gliotoxinas y pigmentos miceliales en $A$. fumigatus, así como para la biosíntesis de heterólogos de lovastatina (genes de $A$. terreus en $A$. nidulans), y lovastatina nativa en $A$. terreus. LaeA influye en la expresión de al menos $9.5 \%$ del genoma de $A$. fumigatus y controla positivamente (20-40\%) la expresión de la mayoría de las vías de MS, incluyendo Péptido Sintetasas no ribosomales (NRPSs), Policétido Sintasas (PKS) y monooxigenasas P450 (Perrin et al., 2007). 
De manera interesante, LaeA parece estar conservada en hongos filamentosos, pero no está presente en S. cerevisiae, un hongo carente de MS (Perrin et al., 2007; Bok y Keller, 2004). Aunque las funciones de LaeA no han sido caracterizadas totalmente, un análisis de 374 aminoácidos de LaeA, muestra la presencia de un dominio de unión de S-adenosil-Lmetionina (SAM), de localización nuclear, sugiriendo que LaeA podría ser una proteína metiltransferasa similar a las histonas metiltransferasas implicadas en la activación y represión transcripcional, ya sea una metiltransferasa de lisina o arginina, en cromosomas eucarióticos.

Aunque no se han realizado estudios bioquímicos directos sobre la especificidad de metilación de LaeA, esta proteína se ha relacionado con cambios en la estructura de la cromatina, modificando dominios cromosomales eucromáticos y heterocromáticos (Bok y Keller, 2004; Bok et al., 2006; Fox y Howlett, 2008; Reyes-Dominguez et al., 2010). Sin embargo, estudios realizados por Patananan et al. (2013) demuestran que LaeA es autometilada sobre un residuo de metionina y que la función de la enzima puede ser como una proteína metiltransferasa de metionina. Experimentos de truncamiento mostraron que el dominio de unión SAM en el extremo N-terminal de LaeA es requerido para su función. LaeA controla una región bien definida de $70 \mathrm{~kb}$ del clúster de ST, una introducción artificial de genes adicionales en esta región da como resultado un patrón de expresión dependiente de LaeA, lo que sugiere que LaeA exhibe una función de control epigenético (Bok et al., 2006). Un nivel de regulación del clúster ST de $A$. nidulans emplea el control epigenético mediante la metilación de H3K9 y la unión a HepA para establecer una estructura de cromatina represiva y LaeA participa en la reversión del estado heterocromático a eucromático dentro del clúster, pero no en genes flanqueantes (Reyes-Domínguez et al., 2010).

Los clústers de genes de MS son mantenidos en heterocromatina, represora de la transcripción, pero son convertidos en eucromatina, que favorece la expresión de estos genes. Las funciones de LaeA inician un proceso que convierte heterocromatina a eucromatina, quizás por interacción con metilasas o desacetilasas (HDAC) que están asociadas con la heterocromatina (Figura 5) (Keller et al., 2005). 


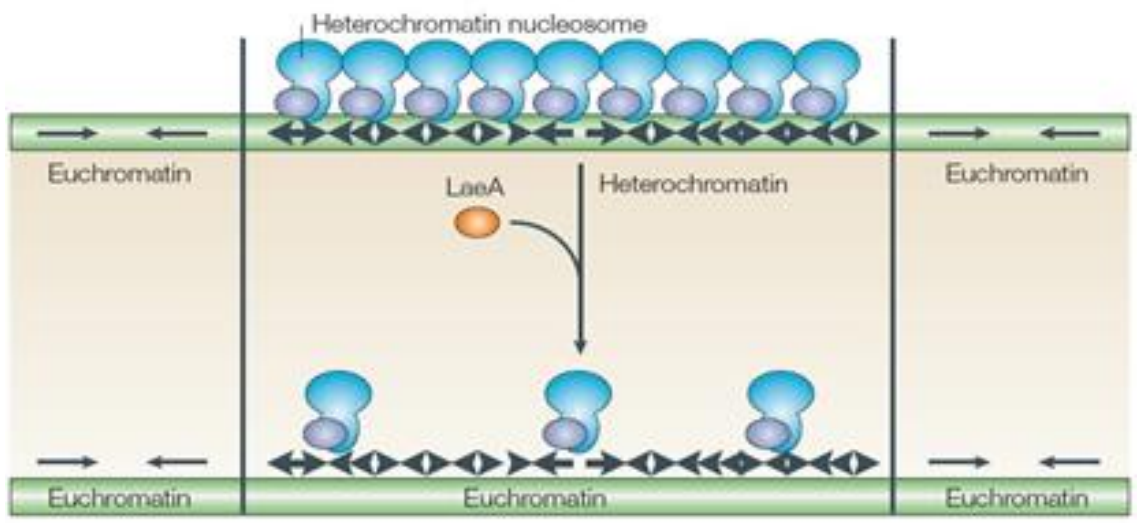

Fig. 5. Modelo de la función de LaeA; Keller et al. (2005).

En 2008 se encontró que LaeA y las dos proteínas de la familia Velvet, VeA y VelB son parte de un complejo trimérico que es esencial para coordinar el metabolismo secundario y el desarrollo en la oscuridad (Bayram et al., 2008b). Por lo tanto, los dos antagonistas de control de la luz, VeA que se requieren para el desarrollo sexual, y LaeA requerido para el desarrollo asexual, deben interactuar físicamente.

LaeA no posee ningún dominio con el complejo Velvet, pero tiene una gran importancia en la interacción con este complejo. LaeA se encuentra principalmente en el núcleo y además de ser un regulador global de MS, tiene funciones clave en el desarrollo. Una visión global de la interacción molecular entre las proteínas del complejo Velvet, LaeA y otras proteínas reguladoras nucleares en respuesta a diversas vías de transducción de señales comienza a emerger de un rompecabezas de varios estudios recientes (Bayram y Braus, 2012).

\section{Complejo Velvet}

La familia de proteínas reguladoras Velvet es exclusivamente fúngica y se encuentra altamente conservada entre los ascomicetos y basidiomicetos (Ni y Yu, 2007). Las proteínas reguladoras de la familia Velvet juegan un papel clave en la coordinación del metabolismo secundario y procesos de diferenciación tales como la esporulación asexual o sexual y formación de esclerocios o de cuerpos de fructificación. El complejo trimérico Velvet percibe directamente la señal de luz para coordinar el metabolismo secundario y el desarrollo de sensores de luz (Bayram et al., 2010). 
La mayor parte del conocimiento actual se deriva del modelo de $A$. nidulans, donde VeA, el miembro fundador de esta familia de proteínas fue descubierto hace casi medio siglo. La deleción del gen veA en $A$. nidulans condujo a un fallo de la producción de ST debido a la disminución en la transcripción de AfIR (Kato et al., 2003). Esto establece una conexión de regulación del metabolismo secundario de hongos y el desarrollo, con la proteína codificada velvet $A$ (vea) como un factor clave (Kato et al., 2003), además mutantes veA1 permitieron la formación de conidios en ausencia de luz, sugiriendo que la proteína VeA juega un papel crucial en la formación de conidios inducida por luz roja (Mooney y Yager, 1990). VeA representa sólo uno de los cuatro miembros de la familia Velvet. VelB (Velvet B) se ha descrito como un regulador dependiente de la luz del desarrollo fúngico y metabolismo secundario en A. nidulans, que interactúa con VeA.

VosA (viabilidad de las esporas A), es otro compañero de interacción de VelB, se identificó como represor de alta copia del desarrollo asexual en $A$. nidulans (Ni y Yu, 2007; Bayram et al., 2010). VosA-VelB forman un complejo dimérico que está presente en las hifas vegetativas y durante el desarrollo en la oscuridad donde se inicia el desarrollo sexual. VosA-VelB proporcionan trehalosa para soportar la viabilidad asexual, así como esporas sexuales. Presumiblemente, esta función se cumple durante el crecimiento vegetativo, porque VosAVelB sólo está presente durante el desarrollo en la oscuridad cuando se tiene una segunda función, apoyando la represión del desarrollo asexual. Con luz, cuando el desarrollo asexual es favorable, casi ninguna VosA o VelB es detectable. Proteínas relacionadas con VosA o VelB de la familia Velvet pueden tener diferentes funciones en la diferenciación de otros hongos y también pueden ser vinculados a los distintos disparadores ambientales. El papel de VelC, el cuarto miembro de la familia Velvet, es aún desconocido y podría ser auxiliar. La supresión de velC en $A$. nidulans resultó en un ligero aumento en la formación de cuerpos de fructificación sexual (Bayram et al., 2010).

La cantidad del complejo trimérico Velvet se reduce en presencia de luz cuando el cuerpo de fructificación y producción ST son reprimidos en $A$. nidulans. VeA forma el factor de puente de respuesta a la luz que une VelB a LaeA. El dímero VelB-VeA se forma en el citoplasma, debido a VelB requiere VeA para el transporte nuclear y el complejo trimérico solamente se forma en lugares nucleares específicos. VelB y VeA son esenciales para la formación de cuerpos de fructificación, mientras que LaeA es esencial para formar células Hülle sexuales y de apoyo a 
la formación de esporas asexuales en un entorno apropiado, tal como la luz. La inducción del clúster del metabolito secundario mediada por LaeA podría servir como una protección para las células Hülle y para la maduración de cleistotecios contra competidores en el suelo (Bayram y Braus, 2012). LaeA además de ser un regulador global para MS, presumiblemente se modula en su actividad con las proteínas de la familia Velvet (VelB y VeA), durante el desarrollo en la oscuridad. Durante respuesta a la luz, LaeA reduce los niveles de VelB y VosA y, por lo tanto, el heterodímero VosA-VelB es difícilmente detectable. Esto libera la represión del desarrollo asexual que se lleva a cabo durante el desarrollo en la oscuridad.

Por otra parte, LaeA protege a VeA contra significativas modificaciones post-traduccionales (Bayram et al., 2008b, 2010). La falta de LaeA resulta en la hiperfosforilación de VeA, que se sabe es una fosfoproteína (Purschwitz et al., 2009). En A. flavus se demostró que laeA es un regulador negativo en la transcripción de veA (Kale et al., 2008). Además, el incremento en la expresión de veA resulta en una disminución de la expresión de laeA (Amaike y Keller, 2009) sugiriendo un control regulatorio de retroalimentación transcripcional negativo mutuo. Por otra parte, se encontró un regulador adicional, llamado rsmA (remediación de metabolismo secundario), cuya sobreexpresión remedia la falta de ST en cepas $\Delta v e A$ y $\Delta l a e A$. Sin embargo, las disfunciones del desarrollo de las cepas no pudieron ser rescatadas por la sobreexpresión del gen rsmA. Por lo tanto, el modelo molecular de la función de RsmA en el complejo Velvet sigue siendo poco clara (Shaaban et al., 2010). Además, la deleción del gen laeA provoca un deterioro en la formación de conidios de $P$. chrysogenum (Hoff et al., 2010) y donde una mutante $\Delta l a e A$ es incapaz de reprimir el desarrollo sexual por luz (Bayram et al., 2010).Esto refleja en un nivel molecular que LaeA es mucho más que un regulador global del metabolismo secundario y desempeña un papel clave en el control del desarrollo en la luz en A. nidulans, mediante el control de la cantidad y la modificación de las proteínas de la familia Velvet (Bayram y Braus, 2012). 


\section{Otros reguladores específicos importantes}

AtfB

Los organismos vivos, incluyendo hongos y plantas utilizan una variedad de mecanismos de transducción de señales para detectar y responder a las diferentes formas de estrés ambiental, y se encuentran conservadas evolutivamente estás vías en hongos filamentosos. La visión clásica de la respuesta al estrés oxidativo ha sido estudiada en levadura, observándose que la modulación de la transcripción de genes relacionados con la defensa antioxidante ayuda a la supervivencia del organismo. Como las levaduras, los hongos filamentosos deben responden al estrés oxidativo, pero, debido a la gran variedad de condiciones ambientales a las que ellos hacen frente, su respuesta es más extensa y complicada que las levaduras. Estudios recientes proporcionan soporte sólido de que la regulación del metabolismo secundario está estrechamente ligada y es parte crucial de la respuesta celular al estrés oxidativo en hongos filamentosos (Miranda et al., 2013, 2014; Reverberi et al., 2006; Roze et al., 2011; Reverberi et al., 2012; Yin et al., 2012; Hong et al., 2013).

Los datos disponibles sugieren fuertemente que varios factores de transcripción asociados con la vía SAPK/MAPK (proteína quinasa activada por estrés/proteína quinasa activada por mitógeno) coordinan el tiempo y el nivel de expresión de genes diana, incluyendo genes antioxidantes y del metabolismo secundario, controlando así los procesos metabólicos con respuesta al estrés celular. En A. parasiticus, Hong et al. (2013) propusieron que las enzimas antioxidantes representan la primera línea de defensa contra la formación excesiva de especies reactivas de oxígeno (EROS) y que la síntesis de MS funciona como una segunda línea de defensa contra los daños de EROS. Así, la biosíntesis de AF, se activa e intensifica por la acumulación de EROS. El factor de transcripción bzip AtfB, relacionado con el estrés oxidativo, es un factor clave en coordinar la expresión de genes antioxidantes y genes implicados en la biosíntesis de AF (Reverberi et al., 2006; Hong et al., 2013).

AtfB es un miembro de la familia CREB/ATF que se une a sitios CRE (5'TG / TACGTC/AA3'). Una interupción de atfB en $A$. oryzae mostró disminución de la transcripción de genes diana antioxidante tal como catA (catalasa específica de conidios) y producción de conidios sensibles a $\mathrm{H}_{2} \mathrm{O}_{2}$ (Sakamoto et al., 2009). El gen atfB se expresó en fase de crecimiento tardía durante la formación de conidios en medio sólido. En A. parasiticus, se demostró que AtfB es un

Tesis de Doctorado en Biotecnología 
importante co-regulador que se unen a promotores de genes de biosíntesis de $\mathrm{AF}$ incluyendo nor-1, fas-1, ver-1, y omtA, los cuales llevan sitios CRE, así como genes de respuesta al estrés, tales como cat1 específico de micelio y sod específico Mn de mitocondria (Roze et al., 2011; Hong et al., 2013). Las mutaciones en el sitio de unión CRE en el promotor nor-1 reduce la transcripción de nor-1 tras la inducción de AMPc exógeno. Estos datos indicaron que la vía AMPc-PKA regula la biosíntesis de AF, al menos en parte a través de AtfB (Roze et al., 2004). Por lo tanto, AtfB regula la expresión coordinada de genes de AF y genes antioxidantes. Datos recientes también apoyan la probable existencia de una red de regulación de factor de transcripción que consiste en AtfB, AP-1, MsnA, SrrA, y AfIR; esta red, junto con otros componentes de señalización, promueve la respuesta de hongos por estrés oxidativo (Hong et al., 2013; Roze et al., 2004). Los autores propusieron que los niveles elevados de EROS intracelulares activan antioxidantes y genes de AF a través de dos vías de transducción de señales. En este modelo, EROS regula negativamente la vía AMPc-PKA, lo que resulta en la unión de MsnA a sitios STRE (CCCCT) en los promotores de los genes antioxidantes para su activación. Al mismo tiempo, EROS regula positivamente la cascada de señalización SAPK/MAPK a través del sistema de fosforilación de múltiples etapas (un análogo del sistema regulador de dos componentes bacteriana) y modula la actividad de una serie de factores de transcripción relacionados con estrés oxidativo/osmótico, tal como la unión de AtfB y SrrA a los promotores e inducción de genes antioxidantes. MsnA, AtfB, y SrrA (SrrA recluta a Yap-1). A continuación, se unen a promotores de genes biosintéticos de AF para ayudar en su inducción por el factor transcripcional específico del clúster, AfIR (Hong et al., 2013). Los factores de transcripción, dependiendo de su estado de activación, alteran la expresión de genes diana implicados en la respuesta celular a las señales de estrés. (Banuett 1998; Toone y Jones, 1998; Toone et al., 2001; Ikner y Shiozaki, 2005; Aguirre et al., 2006; Bahn et al., 2007; Miskei et al., 2009). Existen factores de transcripción con doble funcionalidad (hacia señalización EROS y el metabolismo secundario) que sirve como un fuerte apoyo a la afirmación de que el metabolismo secundario es una parte crucial de la respuesta celular al estrés oxidativo en hongos filamentosos. 


\section{MsnA}

MsnA2 y MsnA4 en S. cerevisiae son factores de transcripción dedos de zinc Cys2His2 que se inducen como parte de la respuesta celular al estrés oxidativo, y otros tipos de estrés, como privación de carbono, shock térmico y estrés osmótico (Martínez-Pastor et al., 1996). Son requeridos para la transcripción de genes que codifican proteínas con funciones de protección al estrés. MsnA2 y MsnA4 se unen a promotores de proteínas que contienen elementos de respuesta al estrés (STRE;CCCCT) y activan la transcripción de genes de respuesta al estrés, tales como CTT1 (catalasa T) y HSP12 (proteína 12 de shock térmico). Se sabe que la actividad Msn2/4 se inhibe por la proteína quinasa dependiente de AMPc (PKA) (Hong et al., 2013).

La deleción de msnA (un ortólogo de MsnA2) en A. parasiticus y A. flavus resultó en una cierta inhibición del crecimiento, pero aumento la producción de conidios, EROS, AF, y ácido kójico (Chang et al., 2011). Así la disrupción de msnA regulo positivamente la expresión de genes que codifican enzimas que protegen contra ROS (ejemplo: superóxido dismutasa, catalasa putativa y citocromo $\mathrm{C}$ peroxidasa en $A$. parasiticus y catalasa $\mathrm{A}$ en $A$. flavus). Estos resultados podrían implicar que la deleción de $m s n A$ regula negativamente la expresión de la catalasa micelial (A. parasiticus) y la catalasa $\mathrm{B}$ (en $A$. flavus), pero a su vez, regula positivamente la expresión de otros genes antioxidantes para la defensa de hongos y hacer frente a mayores niveles de EROS (Hong et al., 2013).

En estudios in vivo en levadura, se mostró que la ocupación de elementos STRE es incrementada en células estresadas y dependientes de la presencia de Msn2p y Msn4p. Ambos factores fueron acumulados en el núcleo bajo condiciones de estrés, como shock térmico moderado, privación de fuente de carbono, estrés osmótico, y presencia de alcohol y sorbato. La localización nuclear de Msn2p y Msn4p se correlaciono inversamente con los niveles de AMPc y actividad de PKA. La activación de la vía Ras/AMPc/PKA conduce a la fosforilación de Msn2 por PKA, la cual causa acumulación citoplásmatica de Msn2 e inhibición de la respuesta general de estrés. (Estruch and Carlson, 1993; Marchler et al., 1993; Görner et al., 1998; Görner et al., 2002; Jacquet et al., 2003). La respuesta al estrés mediada por Msn2 y Msn4 es regulada negativamente por la vía Ras/AMPc/PKA. Experimentos por inmunotransferencia en S. cerevisiae, encontraron que Msn2p y Msn4p son fosforilados in vivo 
durante el crecimiento en glucosa, y son hiperfosforilados en la transición diauxico y choque térmico. Un aumento de los niveles AMPc previene e invierte estas hiperfosforilaciones, indicando que quinasas distintas de PKA están involucradas. Estos resultados sugieren que PKA y quinasas activadas por estrés controlan actividad de Msn2/4p por fosforilación antagónica. Msn2p y Msn4p presentan diferentes patrones de hiperfosforilación en respuesta a diferentes tipos de estrés (Garreau et al., 2000).

\section{CONIDIACIÓN}

El control del metabolismo secundario en los hongos a menudo se coordina con el crecimiento y el desarrollo (Calvo et al., 2002; Yu y Keller, 2005; Braus et al., 2010). El éxito evolutivo de los hongos se basa en su capacidad para explorar y conquistar nuevos nichos ecológicos. Las hifas son estructuras tubulares que se producen después de la germinación de una espora fúngica (Steinberg, 2007; Harris, 2009). Los hongos filamentosos, con la excepción de hongos dimórficos, tienen que desarrollar hifas vegetativas antes de que puedan proceder a otros programas de desarrollo. Por lo tanto, las hifas vegetativas tienen que llegar a un estado de competencia, que define la capacidad de diferenciación de una hifa fúngica en virtud de la susceptibilidad a las señales ambientales tales como la disponibilidad de nutrientes, feromonas por hongos, condiciones de estrés, superficie sólida, suministro de oxígeno y relación entre el dióxido de carbono y oxígeno, o la luz de diferentes longitudes de onda (Axelrod et al., 1973).

El tiempo de competencia depende de la tasa de crecimiento del hongo. La combinación entre la competencia de desarrollo y las señales del medio ambiente no sólo conduce a una mayor diferenciación de las hifas de hongos, sino también a cambios en el metabolismo secundario. Un bajo desarrollo a menudo coincide con la pérdida de función en la producción de ciertos MS que sirven para la adquisición de nutrientes, la protección del hongo o para interactuar con el medio ambiente (Braus et al., 2002, 2010; Bayram et al., 2010; Rodríguez-Romero et al., 2010). El desarrollo en hongos incluye la transición de los cuerpos fructíferos a la formación de esporas asexuales y sexuales (Bayram y Braus, 2012). Esto corresponde a un cambio drástico en los módulos filamentosos de cuerpos fructíferos unitarios, donde la reconstrucción requiere degradación de proteínas funcionales y maquinaria conjunta (Braus et al., 2010; 
Helmstaedt et al., 2011). Los cuerpos fructíferos comprenden células altamente especializadas para la formación de tejidos y el desarrollo meiospore (esporas de la reproducción sexual), y se presentan en diferentes formas, como por ejemplo los peritecios de $N$. crassa y $S$. macrospora, o los cleistotecios cerrados de A. nidulans (Busch y Braus, 2007; Pöggeler et al., 2006). Varios Aspergillus producen un segundo tipo de célula que fue descrito originalmente como clamidosporas. Son células Hülle de pared gruesa, cuya función es proteger y nutrir el cleistotecio maduro (Pantazopoulou et al., 2007; Bayram et al., 2010). Las células Hülle son producidas por diferentes especies del género Aspergillus, incluyendo $A$. nidulans y $A$. heterothallicus, donde se asocian con cleistotecios, mientras que en especies tales como $A$. protuberus y $A$. ustus, las células Hülle se forman en masas, pero no en contacto con cleistotecios (Muntanjola y Vukic, 1972; Ellis et al., 1973; Carvalho et al., 2002).

El desarrollo asexual es típico para la mayoría de los hongos, mientras que la reproducción sexual es menos común y se tiene menos conocimiento (Bayram y Braus, 2012). La conidiación es un proceso común y complejo en el género Aspergillus de la reproducción asexual, donde un gran número de conidios (esporas asexuales) se desarrollan en conidióforos (Park y Yu, 2012; Adams et al., 1998; Krijgsheld et al., 2013). Después de la germinación de un conidio, se forma la colonia que consta de hifas apicalmente pluripotentes que crecen radialmente y producen filamentos indiferenciados llamados micelios (Adams et al., 1998; Kues y Fischer; 2006). Detrás de la zona periférica en hifas superficiales, los cambios en las concentraciones de gas (relación de $\mathrm{O}_{2} / \mathrm{CO}_{2}$ ) (Yang y Lucas, 1970) e iluminación (Calvo, 2008) inducen la diferenciación y el desarrollo de conidióforos. Cualquier condición de estrés como escasez de nutrientes, osmótica o salina (Calvo, 2008; Skromne et al., 1995; Etxebeste et al., 2009), induce el desarrollo de conidióforos, que a su vez afecta profundamente el patrón metabólico de colonias mediante el aumento de MS en las hifas aéreas y la intensificación de los procesos autolíticos (Calvo, 2008; Emri et al., 2008).

El regulador temprano del desarrollo de conidióforos es BrlA, un factor de transcripción dedos de zinc de tipo $\mathrm{C}_{2} \mathrm{H}_{2}$ (Adams et al., 1998; Adams et al., 1988). La activación de brlA es crucial en el desarrollo de conidióforos, la expresión de brlA activa de forma sencilla el desarrollo de conidióforos con la producción de conidiosporas (Adams et al., 1988). La expresión de brlA en células vegetativas conduce a la activación de genes aba $A$ y wet $A$, el cese de crecimiento vegetativo, vacuolización celular, y conidiogénesis (Mirabito et al., 1989). Corriente arriba de 
BrlA, se localizan un conjunto de proteínas Flb, FlbB (Xiao et al., 2010; Etxebeste et al., 2008), FlbC (Kwon et al., 2010), FlbD (Arratia-Quijada et al., 2012; Wieser y Adams, 1995), y FlbE (Kwon et al., 2010); las cuales regulan la actividad del gen brlA. En el núcleo, FlbB y FlbE son necesarios para la adecuada expresión de laeA (un regulador nuclear del complejo Velvet) (Jain y Keller, 2013), producción de gliotoxina (Xiao et al., 2010), y virulencia en A. fumigatus (Kim et al., 2013). La función de los genes flb está bajo la actividad de FluG (Park y Yu, 2012; Adams et al., 1998; Krijgsheld et al., 2013; Kues y Fischer; 2006; Etxebeste et al., 2008; Wieser et al., 1994; Mah y Yu, 2006; Yu, 2010; Ogawa et al., 2010) y el control de regulación del complejo Velvet (Park y Yu, 2012; Etxebeste et al., 2008). En cepas mutantes con deleción de fluG en $A$. nidulans, se observó pérdida de producción $\mathrm{ST}$, mientras que, en $A$. flavus la biosíntesis de AF no se vio afectada por dicha deleción (Chang et al., 2012).

\section{MEJORAMIENTO GENÉTICO}

Es relevante saber que, tanto en FS como en FL a nivel industrial, la cepa es un factor clave en el desarrollo de un proceso de producción comercial competitivo. Sin embargo, poca atención se ha dirigido hacia el desarrollo de métodos y estrategias para generar cepas especiales (Barrios-González y Mejía, 2009). Por lo que, hay necesidad de generar nuevas estrategias y métodos de mejora genética para obtener cepas especiales, particularmente para FS. Estos métodos contribuirán a obtener el máximo potencial de la FS, por lo que este sistema de cultivo puede competir favorablemente con los procesos convencionales e industriales de la FL.

La ciencia y tecnología de manipulación y mejoramiento tienen como objeto la obtención de cepas mejoradas mediante el aumento de sus capacidades metabólicas para aplicaciones biotecnológicas. El éxito en el desarrollo de la industria de la fermentación competitiva depende del mejoramiento continuo de la cepa productora, que es considerada el corazón de una fermentación industrial, que usualmente se traduce en el aumento de producción del metabolito de interés, posibilitando la reducción de costos del proceso. No obstante, otras características también pueden ser mejoradas, como la eliminación de otros metabolitos no deseados, mejorar la utilización de fuentes de $\mathrm{C}$ y N, alteración de la morfología celular para 
separar el micelio del producto y/o mejorar la transferencia de oxígeno en el fermentador. Hoy en día, las cepas mejoradas pueden obtenerse por dos estrategias alternativas: métodos genéticos clásicos (incluyendo recombinación genética) y métodos de mejoramiento genético molecular (Barrios-González et al., 2003).

Los métodos de mejoramiento genético molecular son aplicados para la caracterización de cepas sobreproductoras, duplicación efectiva ó amplificación de genes biosintéticos de metabolitos secundarios (amplificación de un gen objetivo o toda la vía biosintética), inactivación de vías competitivas, interrupción y amplificación de genes regulatorios, incremento de genes específicos de vías de secreción, incorporación de una nueva actividad enzimática y biosíntesis combinada (Barrios-González et al., 2003). Una estrategia avanzada para generar cepas sobreproductoras de MS, sobretodo para FS, es la sobreexpresión de genes reguladores positivos. Un candidato muy interesante fue el gen lae $A$, descrito originalmente como un regulador positivo global del metabolismo secundario en Aspergillus spp. y otros hongos (Bok et al., 2006; Bayram et al., 2008; Lodeiro et al., 2009; Hoff et al., 2010).

\section{JUSTIFICACIÓN}

La vía AMPc-PKA es importante ya que, por primera vez se logra relacionar condiciones ambientales como estrés nutricional y otros tipos de estreses, con una vía de señalización que llega, por un lado, hasta la expresión de genes de biosíntesis de metabolitos secundarios y por otro, a la esporulación.

Actualmente distintos proyectos de nuestro grupo de investigación se enfocan en la identificación de las señales ambientales en cultivo sólido y sus vías de transducción que inducen los genes reguladores, factores de transcripción y los clústers de genes biosintéticos. Respecto a la vía de transducción de señales, es importante conocer los niveles de expresión de genes y cuantificación de algunas proteínas o componentes, en las distintas fases del ciclo celular, ya que puede ser parte de la fisiología distinta de las cepas en la producción de metabolitos secundarios tanto para FS como FL. 
A pesar de que la fisiología del medio sólido y su base molecular están empezando a estudiarse con profundidad y a ser entendido, se ha dado un importante esfuerzo a la investigación en los últimos años referente a estos temas, lo que ha mejorado en gran medida su comprensión. Por otra parte, los avances recientes están empezando a dibujar un panorama interesante y amplio, mientras que muchos descubrimientos básicos también están empezando a ser aplicado a nuevos métodos genéticos de mejora, sistemas de cultivo novedosos, y otros avances tecnológicos. Por otra parte, este tema también está despertando interés entre los investigadores de las industrias farmacéuticas, ya que ahora son conscientes que muchas de las importantes nuevas moléculas bioactivas sólo se pueden obtener por FS, y no por FL. También, debido al interés en los estímulos ambientales que podrían convertirse en crípticos de vías de MS identificados por la genómica (Barrios-González, 2012).

Además de la importancia básica, una mayor conocimiento y comprensión de la vía AMPcPKA y su relación con la fisiología del medio sólido, sería invaluable realizar mejoramiento genético molecular como un aspecto aplicativo, y ampliar aún más el avance tecnológico, como el desarrollo de métodos para generar cepas sobreproductoras de lovastatina (y otros MS) especiales para FS o bien para FL, además de posibilitar el diseño de sistemas de producción más eficientes.

Una estrategia avanzada como se menciono antes es generar cepas sobreproductoras de MS, mediante la sobreexpresión de genes reguladores positivos. Un candidato muy interesante fue el gen laeA, ya que, además, de ser un regulador positivo global del metabolismo secundario, hay pruebas de que está involucrada en la cascada de señalización AMPc-PKA. Esta vía detecta señales ambientales y nutricionales del entorno. Es posible entonces que, caracterizando transformantes del gen laeA sobreexpresado (Pérez et al., 2015), podrían ser observados diferentes efectos en FS y ampliar aun más el conocimiento de la fisiología del medio sólido. 


\section{HIPÓTESIS}

El funcionamiento de la actividad de la vía AMPc-PKA es diferente en fermentación sólida y fermentación líquida en $A$. terreus.

\section{OBJETIVOS}

\section{Objetivo general}

Evaluar el funcionamiento de la vía de señalización AMPc-PKA en A. terreus en la producción de lovastatina en FS y FL, además, establecer sí la sobreexpresión del gen regulador laeA, como una aplicación de dicho estudio, es un buen método de sobreproducción de lovastatina, particularmente FS.

\section{Objetivo particulares}

1. Medir parámetros fisiológicos en la producción de lovastatina en FS y FL en Aspergillus terreus. Además, determinar niveles de expresión de los genes fadA, laeA, lovE, lov $F$, $b r l A$, atfB y $m n s A$ en trofofase e idiofase, en ambos sistemas de cultivo.

2. Evaluar el funcionamiento de la actividad de la vía AMPc-PKA en FS y en FL, midiendo la concentración intracelular de AMPc y el perfil de actividad PKA, tanto en FS como FL.

3. Establecer el efecto de la sobreexpresión del gen laeA (SE::laeA) sobre la producción de lovastatina en FS y en FL, sobre el crecimiento, esporulación y resistencia a estrés, analizando parámetros y expresión génica. 


\section{MATERIALES Y MÉTODOS}

\section{CEPA UTILIZADA}

La cepa Aspergillus terreus TUB F-514, de la colección de Technical University of Budapest, Hungría (Szakács et al., 1998), el genoma haploide es de aprox. 35 Mb, organizado en 8 cromosomas. Linaje: Eukaryota; Fungi; Dikarya; Ascomycota; Pezizomycotina; Eurotiomycetes; Eurotiomycetidae; Eurotiales; Trichocomaceae; mitosporic Trichocomaceae; Aspergillus; Aspergillus terreus.

(https://www.ncbi.nlm.nih.gov/genome/?term=Aspergillus+terreus). Fue crecida sobre medio Power a $30^{\circ} \mathrm{C}$ por 5 días para esporulación. Las esporas fueron colectadas y conservadas en glicerol al $40 \%$.

\section{CONSTRUCCIONES UTILIZADAS}

\section{pUAMTPlaeA}

Plásmido pULC43 de 4.9 kb (Gutiérrez et al., 1997), contiene el gen de resistencia a fleomicina ble de Streptoalloteichus hindustanus $(0.4 \mathrm{~kb})$ expresado bajo el control del promotor del gen pcbC de $P$. chrysogenum $(0.8 \mathrm{~kb})$. Contiene, asimismo la región de terminación del gen cyc1 de $S$. cerevisiae $(0.3 \mathrm{~kb})$. Se integró el gen completo de laeA de $A$. terreus $(2.6 \mathrm{~kb})$, obteniendo la construcción pUAMTPlaeA de 7.5 kb (Figura 6). La dirección del gen integrado, analizado por enzimas de restricción, es de derecha a izquierda $(\rightarrow)$ mediante digestión con Sacll (Pérez et al., 2015).

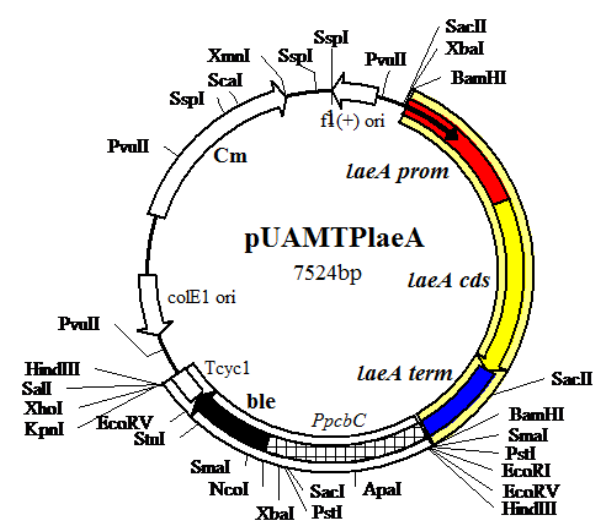

Fig. 6. Construcción pUAMTPlaeA; Pérez et al. (2015). 


\section{pUAMTPIaeAcons}

Plásmido pAN52.1 derivado del pUC19 de 5.5 kb (Punt et al., 1990), con promotor del gen gpd (gliceraldehído 3-fosfato deshidrogenasa) de Aspergillus nidulans como inserto y el terminador del gen trpC. Este promotor ha sido usado por su alto nivel de expresión en hongos. Se le integró la secuencia codificadora del gen laeA de $A$. terreus (1.25 kb), obteniendo la construcción pUAMTPlaeAcons con un tamaño total de 6.75 kb (Figura 7), comprobándose su integración unidireccional mediante digestión con Ncol y BamHI (Pérez et al., 2015).

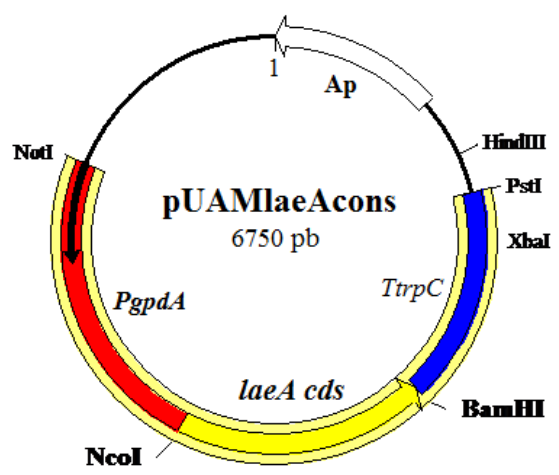

Fig. 7. Construcción pUAMTPlaeAcons; Pérez et al. (2015).

\section{REACTIVOS}

El marcador de tamaños de DNA en geles de electroforesis de agarosa fue usado de 10,000 pb y 1,000 pb (Promega), según el tamaño de DNA a identificar.

Para la purificación de fragmentos DNA el Kit Wizard SV Gel and PCR Clean-Up System (Promega), para obtener DNAc se usó el Kit Express One Step RT-PCR, para el qRT-PCR se usó el Kit EXPRESS One-Step SYBR® GreenER ${ }^{\text {TM }}$ qRT-PCR Universal de Invitrogen, para amplificación de fragmentos de DNA el Go Taq Colorless Master Mix de Promega, para obtención de RNA se utilizó el Trizol de Invitrogen y RQ1 RNase-Free DNase adquirido a Promega. Finalmente, para la detección de bandas se utilizó Bromuro de etidio.

Para la cuantificación de AMPc se utilizó el Kit cAMP Enzyme Immunoassay Direct de Sigma Aldrich. Para la cuantificación de la Actividad de PKA se usó el Kit PKA Kinase Activity Assay (Non Radiactive) de Stressgen y para cuantificación de proteína se usó el Protein Assay de Bio-Rad basado en el método de Bradford. 


\section{EQUIPO}

Equipo utilizado durante el presente trabajo fue: Nanodrop 2000, Cromatógrafo de líquidos de alta resolución (HPLC) (Waters ${ }^{\mathrm{TM}}$ ), UV Crosslinker, Equipo de filtración al vacío (Waters, Millipore), Sonicador (Branson 1210), Bio-espectrofotómetro (Eppendorf), Equipo de qRT-PCR fue un Sistema de detección de fluorescencia Rotor-Gene 3000 (Corbett Research), Microscopio óptico (Olympus), Cámara de electroforesis, Sistema de fotodocumentación GeIDoc con programa Imagen Lab (Bio-Rad), detector Geiger, Sistema de purificación de $\mathrm{H}_{2} \mathrm{O}$ MiliQ (Millipore), Termociclador (Eppendorf), Termomezclador, Centrífuga refrigerada (Eppendorf 5417R), Incubadoras (Lab-Line), Microcentrífugas (Eppendorf 5415C), Microondas (Sanyo), Campana de flujo laminar (Veco), Congeladores de $-20{ }^{\circ} \mathrm{C}$ y $-80{ }^{\circ} \mathrm{C}$, Cuarto de Revelado, Equipo con UV, Micropipetas de diferentes graduaciones, Parrillas con agitación magnética, Balanza analítica, Potenciómetro, Autoclave y Vortex.

\section{MEDIOS DE CULTIVO}

Medio Czapeck: De esporulación y mantenimiento ( $g / L)$

$\begin{array}{lc}\text { Sacarosa } & 30.0 \\ \mathrm{NaNO}_{3} & 2.0 \\ \mathrm{~K}_{2} \mathrm{HPO}_{4} & 0.5 \\ \mathrm{MgSO}_{4} .7 \mathrm{H}_{2} \mathrm{O} & 0.5 \\ \mathrm{FeSO}_{4} .7 \mathrm{H}_{2} \mathrm{O} & 0.01\end{array}$

Medio PMI: De esporulación y mantenimiento ( $\mathrm{g} / \mathrm{L}$ )

Bacto-peptona $\quad 5.0$

Lactosa $\quad 5.0$

$\mathrm{NaCl} \quad 4.0$

Sólidos de maceración $\quad 1.0$

$\mathrm{KH}_{2} \mathrm{PO}_{4} \quad 0.06$

$\mathrm{MgSO}_{4} .7 \mathrm{H}_{2} \mathrm{O} \quad 0.05$

$\mathrm{FeCl}_{3} .6 \mathrm{H}_{2} \mathrm{O} \quad 0.003$

$\mathrm{CuSO}_{4} .5 \mathrm{H}_{2} \mathrm{O} \quad 0.001$ 
Medio Power: De esporulación y mantenimiento

Medio Czapeck $500 \mathrm{~mL}$

Medio PM1 $\quad 500 \mathrm{~mL}$

Agar $\quad 2 \%$

Por cada matraz Erlenmeyer de $250 \mathrm{~mL}$ se colocaron $50 \mathrm{~mL}$ de este medio y se esterilizó a 15 $\mathrm{lb} / \mathrm{in}^{2}$ durante $20 \mathrm{~min}$. Se inoculó $200 \mu \mathrm{L}$ de esporas conservadas en glicerol de $A$. terreus y se incubó a $30^{\circ} \mathrm{C}$ durante 4 días.

Solución de Sales 20X: (g/L)

$\mathrm{NaNO}_{3} \quad 120.0$

$\mathrm{KCl} \quad 10.4$

$\mathrm{MgSO}_{4 .} .7 \mathrm{H}_{2} \mathrm{O} \quad 10.4$

$\mathrm{KH}_{2} \mathrm{PO}_{4}$

Se ajusto a $\mathrm{pH}$ de 6.5 , Se esterilizo a $15 \mathrm{lb} / \mathrm{in}^{2}$ durante $20 \mathrm{~min}$ y se guardó a temperatura ambiente (Ta).

Solución de elementos traza: $(\mathrm{g})$

$\begin{array}{ll}\mathrm{ZnSO}_{4} .7 \mathrm{H}_{2} \mathrm{O} & 2.20 \\ \mathrm{H}_{2} \mathrm{BO}_{3} & 1.10 \\ \mathrm{MnCl}_{2} .4 \mathrm{H}_{2} \mathrm{O} & 0.50 \\ \mathrm{FeSO}_{4} .7 \mathrm{H}_{2} \mathrm{O} & 0.50 \\ \mathrm{CoCl}_{2} .5 \mathrm{H}_{2} \mathrm{O} & 0.16 \\ \mathrm{CuSO}_{4} .5 \mathrm{H}_{2} \mathrm{O} & 0.16 \\ \left(\mathrm{NH}_{4}\right)_{6} \mathrm{Mo}_{7} \mathrm{O}_{24 .} 4 \mathrm{H}_{2} \mathrm{O} & 0.11 \\ \mathrm{Na}_{4} \mathrm{EDTA} & 5.00\end{array}$

Se adicionaron los sólidos en orden en $80 \mathrm{~mL}$ de $\mathrm{H}_{2} \mathrm{O}$, disolviendo cada uno completamente del siguiente. Se calentó a ebullición, se dejó enfriar y ajustando el volumen a $100 \mathrm{~mL}$. 
Medio Completo: Obtención de micelio

Solución de sales 20X $\quad 5 \mathrm{~mL}$

Solución de Elementos Traza $\quad 100 \mu \mathrm{L}$

Glucosa $1 \mathrm{~g}$

Peptona $1 \mathrm{~g}$

Extracto de Levadura $\quad 0.05 \mathrm{~g}$

Se llevó a un volumen de $100 \mathrm{~mL}$ y se ajustó el pH a 6.5 con NaOH 2 M. Por cada matraz Erlenmeyer de $250 \mathrm{~mL}$ se colocaron $50 \mathrm{~mL}$ de este medio y se esterilizó a $15 \mathrm{lb} / \mathrm{in}^{2}$ durante 20 min. Se inocularon esporas por picadura con asa estéril y se incubó a $30{ }^{\circ} \mathrm{C}$ durante aproximadamente $30 \mathrm{~h}$.

Medio de Producción Complejo (g/L): Obtención de lovastatina en cilindros de agar (2.5X), fermentación sólida (2.5X) y fermentación líquida (1X). Para una concentración 2.5X:

$\begin{array}{ll}\text { Glucosa } & 15 \\ \text { Lactosa } & 85 \\ \text { Harina de soya } & 7.5 \\ \mathrm{KNO}_{3} & 5.0 \\ \mathrm{KH}_{2} \mathrm{PO}_{4} & 7.5 \\ \mathrm{NaCl} & 1.25 \\ \mathrm{MgSO}_{4.7} .7 \mathrm{H}_{2} \mathrm{O} & 1.25\end{array}$

Se ajustó el pH a 6.5 con $\mathrm{KOH} 2 \mathrm{M}$ y se llevó al volumen deseado. Se esterilizó a $15 \mathrm{lb} / \mathrm{in}^{2}$ durante $20 \mathrm{~min}$. Para cilindros de agar se añadió $20 \mathrm{~g}$ de agar. 


\section{CONDICIONES DE CULTIVO}

\section{Crecimiento de Aspergillus terreus}

La cepa Aspergillus terreus TUB-514, fue crecida en medio Power durante 4 días a $30^{\circ} \mathrm{C}$ para su esporulación. Las esporas fueron recolectadas con perlas de vidrio estériles con $5 \mathrm{~mL}$ de solución Tween 80 al $0.05 \%$. Se realizó el conteo de esporas en cámara de Neubauer, haciendo cálculos correspondientes para inocular $1 \times 10^{8}$ esporas $/ \mathrm{mL}$ en el medio correspondiente en FS y FL.

\section{Fermentación Sólida (FS)}

Se utilizó poliuretano (puf) como soporte inerte para la fermentación sólida, el cual fue cortado en cuadritos de $1 \times 1 \times 1 \mathrm{~cm}^{3}$, se pre trató con 2 lavados de $\mathrm{NaOH}$ al $40 \%, 2$ lavados con $\mathrm{HCl}$ al $10 \%$ y con varios lavados al agua corriente hasta alcanzar un pH 7. Se realizó el mismo procedimiento de esporulación y recolección de esporas (parental y transformantes) descrito en la fermentación líquida. Se hicieron los cálculos correspondientes para pesar el poliuretano por cada matraz para tener una humedad del $85 \%$, siendo de $0.21 \mathrm{~g} \pm 0.005 \mathrm{~g}$. Se pesó y añadió el poliuretano en matraces de $250 \mathrm{~mL}$ secos, se taparon con papel aluminio y se esterilizaron. Se preparó medio de producción de lovastatina $2.5 \mathrm{X}$ y se esterilizó. En cada matraz con poliuretano, se añadió $5.79 \mathrm{~mL}$ de medio de producción $2.5 \mathrm{X}$ con $2 \times 10^{6}$ esporas, con una espátula estéril se homogeneizó la mezcla con el poliuretano, y se distribuyeron los cuadritos de puf sobre la base del matraz para finalmente tapar con papel aluminio reforzando con parafilm. Se incubó a $30^{\circ} \mathrm{C}$ a días establecidos para análisis.

\section{Fermentación Líquida (FL)}

En cada matraz Erlenmeyer de $250 \mathrm{~mL}$ se preparó $50 \mathrm{~mL}$ de medio de producción de lovastatina $1 \mathrm{X}$ y se esterilizó. Se inoculó $1 \times 10^{8}$ esporas de $A$. terreus por cada matraz y se incubó a $30{ }^{\circ} \mathrm{C}$ a $200 \mathrm{rpm}$ a diferentes tiempos depende el análisis requerido. Se realizó la fermentación de la parental y transformantes por triplicado. 


\section{CUANTIFICACIÓN DE PARÁMETROS FISIOLÓGICOS}

\section{Fermentación Sólida (FS)}

\section{Lovastatina}

En un tubo falcón de $50 \mathrm{~mL}$ se pesó $1 \mathrm{~g}$ de poliuretano y se adicionó $10 \mathrm{~mL}$ de acetonitrilo + agua (1:1). Se agitó $30 \mathrm{~min}$ a $150 \mathrm{rpm}$, posteriormente se pasó al Sonicador durante $30 \mathrm{~min}$ y se filtró con membranas de $0.45 \mu \mathrm{m}$. Se guardó en refrigerador en un tubo epp. La cuantificación de lovastatina (intracelular y extracelular) de los extractos de fermentación sólida y de lovastatina del caldo y micelio de la fermentación líquida se realizó por Cromatografía de Líquidos de Alta Resolución (HPLC-DAD), usando un sistema de Waters con una columna Novapack C-18 (150 x $3.9 \mathrm{~mm}, 4 \mu \mathrm{m})$, con una fase móvil de acetonitrilo : ácido fosfórico 0.1 $\%(60: 40 \mathrm{v} / \mathrm{v})$, la velocidad de flujo fue de $1.5 \mathrm{~mL} / \mathrm{min}$, y la forma $\beta$-hidroxiácida se determinó a $238 \mathrm{~nm}$ con un detector de arreglo de diodos. (Waters 996) (Waters Corporation, Milford, MA USA).

\section{Humedad}

En un papel aluminio previamente pesado, se colocó todo el soporte húmedo restante, se pesó todo en conjunto y se metió al horno a $60^{\circ} \mathrm{C}$ para su secado durante 2 días. Por diferencia de pesos se obtuvo el porcentaje (\%) de humedad. Para obtener el dato de biomasa se utilizó el método de Glucosamina.

$\mathrm{pH}$

En un tubo falcón de $50 \mathrm{~mL}$ se pesó $1 \mathrm{~g}$ de poliuretano y se adicionó $10 \mathrm{~mL}$ de $\mathrm{H}_{2} \mathrm{O}$. Se midió el pH directamente.

\section{Biomasa (Glucosamina)}

De acuerdo con la metodología propuesta por Elson y Morgan (1933). Se requiere de una hidrólisis ácida total para liberar la glucosamina de la pared celular en los hongos. La glucosamina liberada se combina con acetil acetona para formar un compuesto pirólico, éste reacciona con para-dimetil amino benzaldehído (PDBA) para formar un compuesto estable, de color rojo con un máximo de absorbancia a $530 \mathrm{~nm}$. En un tubo de vidrio se colocó el soporte seco restante en el muestreo, se agregó $5 \mathrm{~mL}$ de $\mathrm{H}_{2} \mathrm{SO}_{4}$ al $72 \%$, se incubó a $25^{\circ} \mathrm{C}, 130 \mathrm{rpm}$ por 30 min. Posteriormente se diluyó con $54 \mathrm{~mL}$ de $\mathrm{H}_{2} \mathrm{O}$ y se esterilizó la mezcla $1 \mathrm{~h}$ a $121^{\circ} \mathrm{C}$. Se neutralizó la mezcla a un pH 7.0 con $\mathrm{NaOH} 10 \mathrm{M}$, se anotó el volumen. Se centrifugó a 
5,000 rpm durante $10 \mathrm{~min}$, se tomó $2 \mathrm{~mL}$ de la muestra hidrolizada (sobrenadante) y se agregó $1 \mathrm{~mL}$ de la solución $\mathrm{A}^{1}$ (preparación reciente), $1 \mathrm{~mL}$ de $\mathrm{H}_{2} \mathrm{O}$, y se puso en baño maría durante $15 \mathrm{~min}$. Se enfriaron los tubos en hielo y se adicionó $4 \mathrm{~mL}$ de etanol, $1 \mathrm{~mL}$ de reactivo $\mathrm{B}^{2}$ y 1 $\mathrm{mL}$ nuevamente de etanol, se agitó y se dejó reposar $1 \mathrm{~h}$ en oscuridad. Se determinó la densidad óptica a $530 \mathrm{~nm}$. La concentración de glucosamina producida en las muestras se obtuvo con la linealización de una curva estándar cuyas concentraciones fueron de 0 a 100 $\mathrm{mg} / \mathrm{mL}$ de glucosamina.

\section{Fermentación Líquida (FL)}

\section{Biomasa y humedad}

Se tomó el matraz y se filtró el micelio en papel filtro (previamente pesado). Se anotó el peso del papel filtro y papel filtro + micelio. Después de secar el papel filtro + micelio por 2 días en horno a $60^{\circ} \mathrm{C}$, se volvió a pesar y con estos datos se obtuvo el porcentaje (\%) de humedad y la cantidad de micelio producido.

\section{Lovastatina en caldo}

Del caldo obtenido después de la filtración, en un tubo falcón de $50 \mathrm{~mL}$ se tomaron $2 \mathrm{~mL}$ y a éste se le adicionó $2 \mathrm{~mL}$ de acetonitrilo + agua (1:1). Se agitó $30 \mathrm{~min}$ a $150 \mathrm{rpm}$, se filtró con membranas de $0.45 \mu \mathrm{m}$ y se guardó $\mathrm{A} 4^{\circ} \mathrm{C}$ en un tubo epp.

\section{Lovastatina en micelio}

De la biomasa obtenida después del filtrado, en un tubo falcón de $50 \mathrm{~mL}$, se pesó $1 \mathrm{~g}$ de ésta y se le adicionó $10 \mathrm{~mL}$ de acetonitrilo + agua (1:1). Se le agregaron $5 \mathrm{~g}$ de perlas de vidrio, se agitó con vortex durante $1 \mathrm{~min}$, se pasó al sonicador durante $30 \mathrm{~min}$. Se tomó $1 \mathrm{~mL}$ en tubo epp. y se centrifugó a 14,000 rpm por 5 min a Ta, se tomó sobrenadante y se filtró con membranas de $0.45 \mu \mathrm{m}$. Se guardó a $-20^{\circ} \mathrm{C}$.

$\underline{\mathrm{pH}}$

Al final de haber tomado el muestreo para todas las pruebas, se midió el pH directamente en el matraz.

\footnotetext{
${ }^{1}$ Solución A: $1 \mathrm{~mL}$ de Acetilacetona en $50 \mathrm{~mL}$ de $\mathrm{Na}_{2} \mathrm{CO}_{3} 0.5 \mathrm{~N}$.

${ }^{2}$ Solución B: $0.8 \mathrm{~g}$ p-Dimetilaminobenzaldehido (PDBA) en $30 \mathrm{~mL}$ de $\mathrm{HCl}$ y $30 \mathrm{~mL}$ de Etanol.
} 


\section{TÉCNICAS ANALÍTICAS PARA EL ANÁLISIS DE LA ACTIVIDAD DE LA VÍA AMPc-PKA}

\section{Medición en la cuantificación de AMPc}

Se utilizó el Kit cAMP Enzyme Immunoassay Direct, el cual cuantifica el AMPc en células tratados con $\mathrm{HCl}$. El adenosín monofosfato $3^{\prime}, 5^{\prime}$ cíclico (AMPc) es uno de los segundos mensajeros más importantes involucrado como modulador de procesos fisiológicos. EI AMPc también está involucrado en otras funciones como crecimiento celular y diferenciación. En forma general, el anticuerpo se une, de una manera competitiva al AMPc de la muestra o del conjugado durante una incubación simultánea a temperatura ambiente. Se añade la solución de sustrato pNpp (fosfato p-nitrofenil, cromógeno), el cual genera una coloración amarilla cuando es catalizada por la fosfatasa alcalina del conjugado de AMPc (Figura 8). El tratamiento de células y tejidos con $\mathrm{HCl}$ detendrá la actividad de la fosfodiesterasa endógena y permitirá la medición directa de estas muestras en el ensayo.

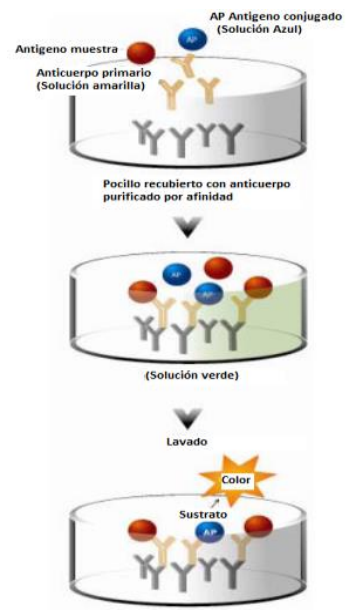

Fig. 8. Método para cuantificación de AMPc.

Se limpió zona de trabajo y pipetas con SDS $1 \%$ y luego con cloroformo, todo el material se esterilizó dos veces. Se sacaron en hielo 2 muestras congeladas de micelio molido de FS (aprox. $0.5 \mathrm{~g}$ biomasa + puf molido $=1 / 2$ tubo) y $2 \mathrm{de} \mathrm{FL} \mathrm{(aprox.} 0.25 \mathrm{~g}$ biomasa filtrada molida $=1 / 4$ tubo). Se homogeneizaron los tubos con $1 \mathrm{~mL}$ de $0.1 \mathrm{M} \mathrm{HCl}$. Se centrifugaron a 3,000 rpm por $10 \mathrm{~min}$. Se tomó el sobrenadante para su posterior análisis. Se colocaron alícuotas de 50 $\mu \mathrm{L}$ de reactivo Neutralizante en cada pozo excepto en los de la Actividad total (TA) y blanco. Después se añadió $100 \mu \mathrm{L}$ de $0.1 \mathrm{M} \mathrm{HCl}$ dentro de NSB (unión no específica) y Bo (pozo 
estándar $0 \mathrm{pmol} / \mathrm{mL}=$ Estándar 0), después $50 \mu \mathrm{L}$ de $0.1 \mathrm{M} \mathrm{HCl}$ a los pozos NSB. Posteriormente se añadió $100 \mu \mathrm{L}$ del Estándar \#1 al $5(0.78,3.13,12.5,50$ y 200 pmol/mL) a pozos etiquetados para estándares. Se agregó $100 \mu \mathrm{L}$ de las muestras a pozos etiquetados para ellas. Después se añadió $50 \mu \mathrm{L}$ del conjugado azul dentro de cada pozo, excepto pozos TA y Bo, y $50 \mu \mathrm{L}$ del anticuerpo amarillo en cada pozo, excepto pozos TA, Bo y NSB. Se sellaron las placas, se incubaron por 2 h con agitación a 500 rpm a Ta. Se vaciaron los contenidos de pozos y se lavó con $400 \mu \mathrm{L}$ de buffer de lavado para cada pozo. Se repitió 2 veces más, para 3 lavados totales. Después se vaciaron los pozos y removió remanente de buffer de lavado. Se pipeteo $5 \mu \mathrm{L}$ de conjugado azul a los pozos TA. Se añadió $200 \mu \mathrm{L}$ de solución de sustrato (cromógeno) dentro de cada pozo. Se incubó 1 h a Ta sin agitar. Se añadió $50 \mu \mathrm{L}$ de solución Stop en cada pozo. Después de blanquear el lector frente al blanco del sustrato, se leyó a densidad óptica de $405 \mathrm{~nm}$. La magnitud de la señal es inversamente proporcional a la cantidad de AMPc en la muestra.

\section{Cuantificación de Actividad Específica PKA}

El Ensayo de Actividad PKA quinasa no radiactivo proporciona un método seguro, rápido y fiable para aislar inhibidores o activadores de PKA y cuantificar la actividad de PKA. EI ELISA (ensayo por inmuno absorción ligado a enzimas) es una técnica que utiliza un péptido sintético específico como sustrato para PKA y un anticuerpo policlonal que reconoce la forma fosforilada del sustrato. El ensayo es diseñado para el análisis de la actividad PKA en solución. En el ensayo, el sustrato, el cual es fosforilado fácilmente por PKA, este pre-revestido en los pocillos de la placa de micro titulación del sustrato PKA. Las muestras se añaden a los pocillos apropiados, seguido por la adición de ATP para iniciar la reacción. La reacción se detiene al añadir el anticuerpo de sustrato fosfoespecífico que se une específicamente al sustrato péptido fosforilado. El anticuerpo fosfoespecífico se une posteriormente por un segundo anticuerpo conjugado peroxidasa. El ensayo es desarrollado con un sustrato tetrametilbenzidina (TMB) que da el color en proporción a la actividad fosfotransferasa de PKA. El desarrollo del color se detiene con una solución ácida de paro y la intensidad del color es medido en un lector de micro placas a $450 \mathrm{~nm}$ (Figura 9). 


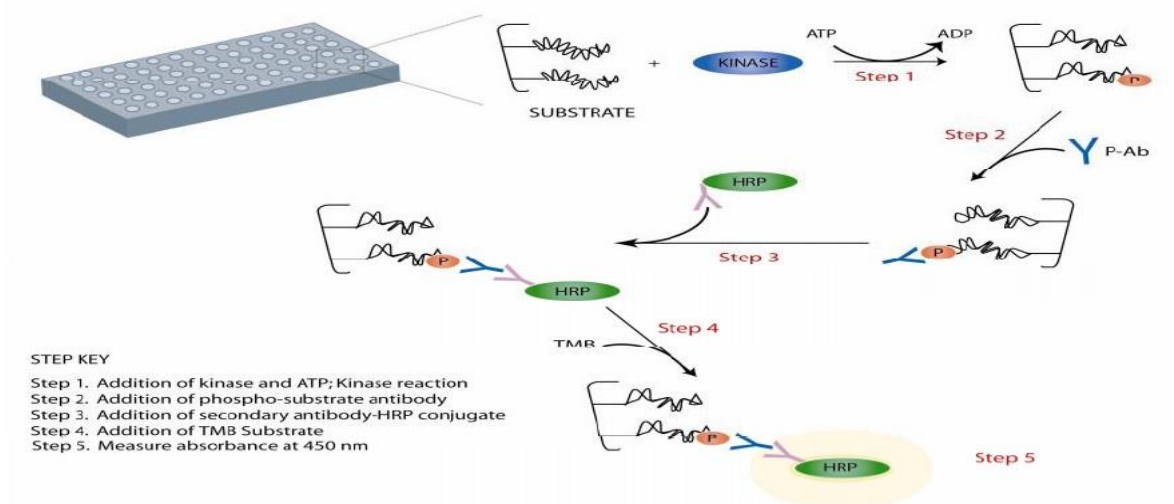

Fig. 9. Método para cuantificación de Actividad PKA.

Se limpió la zona de trabajo y pipetas con SDS $1 \%$ y luego con cloroformo, todo el material se esterilizó dos veces. Se sacaron en hielo 2 muestras congeladas de micelio molido de FS (aprox. $0.5 \mathrm{~g}$ biomasa + puf molido $=1 / 2$ tubo) y 2 de FL (aprox. $0.25 \mathrm{~g}$ biomasa filtrada molida $=1 / 4$ tubo) y se les añadió Buffer de lisis ${ }^{3}$, se resuspendieron muestras y se dejó reposar en hielo durante $10 \mathrm{~min}$, después se pasó a sonicación 3 veces durante 20 seg y se centrifugó a $13,000 \mathrm{rpm}$ durante $10 \mathrm{~min}$ a $4^{\circ} \mathrm{C}$, se recuperó sobrenadante en otro tubo y se dejaron en hielo para posterior análisis. Se remojaron pocillos de la placa de micro titulación con $50 \mu \mathrm{L}$ de buffer de dilución a temperatura ambiente (Ta) durante $10 \mathrm{~min}$. Con cuidado se aspiró líquido de cada pocillo con pipeta. Se añadieron $30 \mu \mathrm{L}$ de muestras en los pocillos respectivos, ya pre-revestidos con el sustrato PKA, excepto en pozos para PKA estándar (proteína activa purificada de $200 \mathrm{pg} / \mu \mathrm{L}$ ) y blanco, las cuales se les adicionó solo buffer de dilución. Se inició reacción mediante la adición de $10 \mu \mathrm{L}$ de ATP diluido a cada pocillo, excepto al blanco. Se incubó durante $90 \mathrm{~min}$ a $30^{\circ} \mathrm{C}$. Se detuvo la reacción vaciando contenido de cada pocillo. Se añadió $40 \mu \mathrm{L}$ de anticuerpo sustrato fosfoespecífico a cada pocillo, excepto al blanco. Se incubó a Ta durante $60 \mathrm{~min}$. Se lavaron pocillos 4 veces con $100 \mu \mathrm{L}$ de tampón de lavado $1 \mathrm{X}$. Se añadió $40 \mu \mathrm{L}$ de conjugado diluido IgG: HRP anti-conejo a cada pocillo, excepto al blanco. Se incubó a Ta durante $30 \mathrm{~min}$. Se lavaron pocillos 4 veces con $100 \mu \mathrm{L}$ de tampón de lavado 1X. Se añadió $60 \mu \mathrm{L}$ de sustrato TMB a cada pocillo y se incubó a Ta durante $60 \mathrm{~min}$. Se añadió $20 \mu \mathrm{L}$ de solución de paro a cada pocillo y se midió absorbancia a $450 \mathrm{~nm}$.

\footnotetext{
${ }^{3}$ Buffer de lisis: 350 mM KH2PO4 pH 7.5, 0.1 DTT y 10\% glicerol.
} 


\section{Cuantificación de Proteína}

Se midió la cuantificación de proteína de los sobrenadantes obtenidos de las muestras tratadas de acuerdo con la técnica usada ya sea para cuantificar AMPc o determinar la actividad PKA. En ensayo utilizado para cuantificar proteína fue el de Bio-Rad basado en el método de Bradford, se efectuó a escala de $\mu$ l por lo que el procedimiento fue un micro ensayo en placas de micro titulación. Se realizó una curva estándar de 8 a $80 \mu \mathrm{g} / \mathrm{mL}$. Se añadieron en sus respectivos pozos $160 \mu \mathrm{L}$ de cada estándar (8 totales), y en otros pozos los sobrenadantes de las muestras ya tratadas según análisis a cuantificar. Cabe notar, que los blancos o estándar 0 fueron distintos para el tipo de muestras a analizar, ya que como se mencionó anteriormente, se trataron las muestras de diferente manera por requerimiento de la técnica a utilizar. Todo se efectuó por triplicado. Se añadió después $40 \mu \mathrm{L}$ del colorante reactivo concentrado a cada pozo, se mezclaron muy bien usando pipeta con movimientos de arriba hacia abajo varias veces. Se incubó a Ta por 5 min y se midió la absorbancia a $595 \mathrm{~nm}$.

\section{ANÁLISIS DE ÁCIDOS NUCLEICOS}

\section{Extracción de DNA genómico de A. terreus}

El método usado para obtener DNA total de hongos a gran escala fue esencialmente descrito por Specht et al., (1982), posteriormente se fue modificando. Se germinaron esporas frescas de $A$. terreus sobre medio completo y se incubaron a $30^{\circ} \mathrm{C}$ durante $30 \mathrm{~h}$. El micelio producido se recogió con palillo estéril, se secó con sanitas y se colocó en un mortero frío, se añadió $\mathrm{N}_{2}$ líquido y se molió. En tubos Eppendorf (epp) fríos se colocaron aproximadamente la mitad de micelio molido para FS y un cuarto del tubo para la FL y se adicionó $800 \mu \mathrm{L}$ de buffer de extracción ${ }^{4}$ y se incubó a $68 \stackrel{\circ}{C}$ por 30 min. Inmediatamente se centrifugó a 14,000 rpm por 5 min a Ta. Al sobrenadante se le agregó $50 \mu \mathrm{L}$ de acetato de potasio (KAc) $5 \mathrm{M} \mathrm{pH} 4.2$, se mezcló suavemente por inversión y se colocó en hielo durante $10 \mathrm{~min}$. Posteriormente se centrifugó a 14,000 rpm por $5 \mathrm{~min}$ a Ta. Se transfirieron $700 \mu \mathrm{L}$ del sobrenadante a otro tubo epp y se adicionaron $700 \mu \mathrm{L}$ de isopropanol, se mezcló suavemente por inversión y se centrifugó a 14,000 rpm por 5 min a Ta. Se resuspendió el pellet con $400 \mu \mathrm{L}$ de $\mathrm{H}_{2} \mathrm{O}$ BM y se agregó $40 \mu \mathrm{L}$ de Acetato de sodio (NaAc) $3 \mathrm{M} \mathrm{pH}$ 7.0. La mezcla se calentó a $68^{\circ} \mathrm{C}$ por $1 \mathrm{~h}$.

\footnotetext{
${ }^{4}$ Buffer de Extracción: EDTA 50 mM y SDS 0.2\%.
} 
Para homogeneizar muestra se agito con vortex y se centrifugó a 14,000 rpm por 5 min a Ta, después se transfirió el sobrenadante a otro tubo epp para proseguir con la extracción. Se agregó $1 \mathrm{~mL}$ de Etanol (EtOH) 95\%, se mezcló suavemente por inversión y se centrifugó a 14,000 rpm por 5 min a Ta. Se lavó 2 veces el pellet con $800 \mu \mathrm{L}$ de EtOH 70\%, mezclando por inversión suavemente y se centrifugó a 14,000 rpm por 5 min a Ta. Se dejo evaporar el OH del pellet por capilaridad invirtiendo el tubo epp. Posteriormente se resuspendió el ADN en 100 $\mu \mathrm{L}$ con solución RNAsa a una concentración de $100 \mu \mathrm{g} / \mathrm{mL}$. La mezcla se calentó a $68 \stackrel{\circ}{\circ}$ por 5 min para resuspender el DNA y se incubó a $37^{\circ} \mathrm{C}$ durante $1.5 \mathrm{~h}$. Después se le adicionaron $300 \mu \mathrm{L}$ de $\mathrm{H}_{2} \mathrm{O}$ BM. Se extrajo el DNA con 1 volumen de CIA (Cloroformo - Alcohol isoamílico), se mezcló suavemente por inversión y se centrifugó a 14,000 rpm por 5 min a Ta. Se recogió la fase acuosa y se añadió $1 / 10$ vol. de NaAc $3 \mathrm{M} \mathrm{pH} 5.2$ (aprox. $40 \mu \mathrm{L}$ ) y 2.5 vol. de etanol frío, se centrifugó a 14,000 rpm por 20 min a $4{ }^{\circ} \mathrm{C}$. El DNA se lavó con $800 \mu \mathrm{L}$ de EtOH $70 \%$, se secó y resuspendió en $30 \mu \mathrm{L}$ de $\mathrm{H}_{2} \mathrm{O}$ BM. Se conservó a $-20^{\circ} \mathrm{C}$.

\section{Extracción de RNA}

Se limpió la zona de trabajo y pipetas con SDS 1\% y luego con cloroformo, todo el material se esterilizó dos veces. Se sacaron 4 muestras de FS (aprox. $0.5 \mathrm{~g}$ biomasa + puf molido = 1/2 tubo) y 4 de FL (aprox. $0.25 \mathrm{~g}$ biomasa filtrada molida = $1 / 4$ tubo) congeladas $\mathrm{a}-80{ }^{\circ} \mathrm{C}$ y se pusieron en hielo. Rápidamente se abrieron y agregaron $1 \mathrm{~mL}$ de Trizol, se taparon, se dio vortex para resuspender polvo en Trizol, y se dejaron nuevamente en hielo reposando $15 \mathrm{~min}$. Se abrieron los tubos y se agregó $200 \mu \mathrm{L}$ de cloroformo, se taparon y se invirtieron varias veces. Se dejó reposar 5 min a temperatura ambiente (Ta). Se centrifugó a 12,000 rpm, $4{ }^{\circ} \mathrm{C}$ por 20 min. Se recuperó la fase acuosa en un tubo nuevo y se lavó nuevamente con $200 \mu \mathrm{L}$ de cloroformo. Se recupero nuevamente la fase acuosa, y se agregó $500 \mu \mathrm{L}$ de isopropanol, se invirtieron varias veces, dejando reposar por $20 \mathrm{~min}$. Se centrifugó a 12,000 rpm, $4^{\circ} \mathrm{C}$ por $20 \mathrm{~min}$. Se vertieron los tubos para tirar sobrenadante y se lavó el precipitado con $1 \mathrm{~mL}$ de $\mathrm{EtOH} 75 \%$, se dio vortex y centrifugó a $7,500 \mathrm{rpm}, 4^{\circ} \mathrm{C}$ por $7 \mathrm{~min}$. Se extrajo el EtOH con pipeta de $1 \mathrm{~mL}$ y se resuspendió el RNA (gelatinoso, sin que seque completamente) con 50 $\mu \mathrm{L}$ de $\mathrm{H}_{2} \mathrm{O}$ BM. Se dieron golpecitos para suspender RNA, se guardaron muestras a $-20{ }^{\circ} \mathrm{C}$.

Tras la extracción de RNA se prosiguió a la purificación del mismo mediante el Kit RQ1 RNaseFree DNase para eliminar ADN presente en muestras. Es importante resaltar que se añadió la solución de paro una vez confirmada la eliminación completa de ADN mediante un gel de 
agarosa $0.8 \%$ corrido a $70 \mathrm{~V}$ por $40 \mathrm{~min}$. Se cuantificó la concentración de RNA total por Nanodrop 2000.

\section{Diseño de oligos para obtener fragmentos DNA}

Para el diseño de los oligos ("primers"), se tomó como base el genoma de Emericella nidulans ubicado en la base de datos del NCBI (National Center for Biotechnology Information) con número de acceso al GenBank:_AY394722.1 y mediante Blastn se encontraron los genes en Aspergillus terreus publicado en esta misma base de datos con número de acceso al GenBank: NT_165972 (https://www.ncbi.nlm.nih.gov/nuccore/NT_165972.1).

Obteniendo los genes de interés en $A$. terreus, se prosiguió al diseño de oligos, con un tamaño entre 20-25 nucleótidos, colchón de 3 nucleótidos en el extremo 5’ y pinza ó clamp en el extremo 3’ (3 ó 4 G/C). Temperatura de hibridación no mayor a $65^{\circ} \mathrm{C}$ y entre ellos no mayor de $2{ }^{\circ} \mathrm{C}$. La sumatoria de $\mathrm{G}$ y $\mathrm{C}$ de los oligos fuera de $60 \%$. Que no hubiera complementariedad con todo el genoma de Aspergillus terreus, (Blast de oligos con el genoma en NCBI). Que no hubiera complementariedad (análisis en DNAman) entre los 2 oligos (Forward y Reverse) ni entre ellos mismos, no más de $4 \mathrm{pb}$ seguidos en continuo y discontinuo, y de ser así, que el extremo $3^{\prime}$ no estuviese libre con muchos nucleótidos que puedan dar inicio a la polimerización.

Al llegar los oligos, se prepararon con $\mathrm{H}_{2} \mathrm{O}$ BM a una concentración de $10 \mu \mathrm{M}$. Los fragmentos de ADNc para qRT-PCR tuvieron un tamaño de entre 100-200 pb y para las sondas entre 300$400 \mathrm{pb}$.

Los oligonucleótidos empleados como cebadores ("primers") para amplificación de fragmentos de DNA, para comprobar integración de construcciones en las mejores transformantes por PCR (plaeAF, plaeAR, plaeAconsF, plaeAcosR) y Southern Blot, para obtener sondas de laeA, lovE y fadA para Northern Blot (identificados por la palabra intermedia son) y para los DNAc de los diferentes genes analizados para curvas estándar en qRT-PCR, se describen a continuación: 
Tabla 1. Diseño de oligonucleótidos

\begin{tabular}{|c|c|c|c|}
\hline Oligos & Secuencia & Sitio de restricción & Tamaño amplificado (pb) \\
\hline PlaeAF & CCAAGAGTGGATAATGGAGTCCC & Terminador lae $A$ & \multirow{2}{*}{1,250} \\
\hline PlaeAR & CGACAGTTGACAGAGCCAATGGC & Promotor $p c b C(b / e)$ & \\
\hline plaeAconsF & CCAGAGGGTCATGACTTGAGC & Promotor gpdA & \multirow{2}{*}{1,444} \\
\hline plaeAconsR & CCACGTCAATTGCCCAGATCC & secuencia codificadora lae $A$ & \\
\hline laeAsonF & GGACGGCTGTACCATGCGTATCG & secuencia codificadora lae $A$ & \multirow{2}{*}{364} \\
\hline laeAsonR & CGCTTCCGCAGCCCATTTGGAGG & secuencia codificadora lae $A$ & \\
\hline lovEsonF & AGCTACGACTGGTCGTGGACCTCG & secuencia codificadora lovE & \multirow{2}{*}{585} \\
\hline lovEsonR & CGACAGGAGCAACTCCGATATGGC & secuencia codificadora lovE & \\
\hline fadAsonF & GCATCGCTCAACCTGATTACCTCC & secuencia codificadora fad $A$ & \multirow{2}{*}{436} \\
\hline fadAsonR & CGGTTGAGGATGTAGTCGCAAGCC & secuencia codificadora fad $A$ & \\
\hline laeArtpcrF & CGAGAACATAATCCTGGCTACAGC & secuencia codificadora lae $A$ & \multirow{2}{*}{122 con RNA con DNA } \\
\hline laeArtpcrR & CCTTTTCGATACGCATGGTACAGC & secuencia codificadora lae $A$ & \\
\hline lovErtpcrF & ACGGACCAAGAACCTCTTTACGGC & secuencia codificadora lovE & \multirow{2}{*}{85 con RNA o DNA } \\
\hline lovErtpcrR & CGACAGGAGCAACTCCGATATGGC & secuencia codificadora lovE & \\
\hline fadArtpcrF & GGACAAGATGTTGCAGCGGAACG & secuencia codificadora fad $A$ & \multirow{2}{*}{$\begin{array}{c}137 \text { con RNA } 210 \text { con } \\
\text { DNA }\end{array}$} \\
\hline fadArtpcrR & CCTTGAAGGATTCCCGTTCATCC & secuencia codificadora fad $A$ & \\
\hline atfBrtpcrF & GACGCAAAATCGAGGACACCGACG & secuencia codificadora atfB & \multirow{2}{*}{135 con RNA o DNA } \\
\hline atfBrtpcrR & TCTGCTCCAGCATCTGCGCCTCC & secuencia codificadora atfB & \\
\hline msnArtpcrF & GGCTGCGAAGGCGATGTCCATGC & secuencia codificadora $m s n A$ & \multirow{2}{*}{$\begin{array}{c}133 \text { con RNA } 223 \text { con } \\
\text { DNA }\end{array}$} \\
\hline msnArtpcrR & CGAGAGGAAATCAGAGCCCTGGC & secuencia codificadora $m s n A$ & \\
\hline lovFrtpcrF & GGAAATGGGGTCAACCTGGTCC & secuencia codificadora lov $F$ & \multirow{2}{*}{$\begin{array}{c}153 \text { con RNA } 218 \text { con } \\
\text { DNA }\end{array}$} \\
\hline lovFrtpcrR & GCTACTGGTTGGATGTTCCACG & secuencia codificadora lovF & \\
\hline brlArtpcrF & ССАСТСССАСААGСАTTTACAGCC & secuencia codificadora brlA & \multirow{2}{*}{92 con RNA o DNA } \\
\hline brlArtpcrR & GGTACGCTCGTATCCGTGAGTCG & secuencia codificadora $b r l A$ & \\
\hline EFrtpcrF & CGTTATCGGCCACGTCGATTCC & secuencia codificadora $E F$ & \multirow{2}{*}{$\begin{array}{c}82 \text { con RNA } \\
\text { DNA }\end{array}$} \\
\hline EFrtpcrR & GGTACGGGAGTCGATACCACCG & secuencia codificadora $E F$ & \\
\hline
\end{tabular}




\section{Números de acceso en el NCBI de genes analizados}

Para el diseño de los oligos anteriores se usó la base de datos NCBI: NCBI: https:/www.ncbi.nlm.nih.gov, y los siguientes números de acceso: para el gen laeA: XM_001210764.1; para lovE: AF141925; para fadA:XM_001210595; para atfB: XM_001211156.1; para msnA:XM_001214486; para lovF: AAD34559.1; para brlA: XM_001214318 y para EF: XM_001212188.

\section{Reacción en cadena DNA polimerasa (PCR)}

Esta técnica es, conceptualmente, un método muy simple para la amplificación de ácidos nucleicos (Saiki et al., 1985; Mullis y Faloona, 1987). El método se basa en la repetición de 3 pasos: desnaturalización, hibridación de los cebadores y elongación, efectuados de forma sucesiva en condiciones de temperatura determinada y controlada. Se usó el Kit Go Taq Colorless Máster Mix de Promega para este proceso, agregando oligos Forward y Reverse a $10 \mu \mathrm{M}$. Se buscó la temperatura de hibridación máxima en los oligos $\mathrm{F}$ y $\mathrm{R}$ para realizar el gradiente, con un rango de $1-2{ }^{\circ} \mathrm{C}$, obteniendo 5 temperaturas a probar para obtener la temperatura óptima de hibridación de los oligos mediante la función de gradiente en el Termociclador. Se repartió la mezcla de reacción en 5 tubos con $20 \mu \mathrm{L}$ cada uno y se procedió a la amplificación en el Termociclador Eppendorf, con el siguiente programa:

1. $\mathrm{T}=94^{\circ} \mathrm{C} \quad \mathrm{Fix}=3 \mathrm{~min}$

2. $\mathrm{T}=94^{\circ} \mathrm{C} \quad \mathrm{Fix}=30 \mathrm{seg}$

3. $T=T_{m}$ intermedia $\quad F i x=50$ seg $\underline{3} O p t$

4. $\mathrm{R}=3^{\circ} \mathrm{C} / \mathrm{s} \quad \mathrm{G}=2-4^{\circ} \mathrm{C}$

5. $\mathrm{T}=72^{\circ} \mathrm{C} \quad \mathrm{Fix}=$ tiempo según tamaño a amplificar

6. Go to $=2$ Repetición $=35$

7. $\mathrm{T}=72^{\circ} \mathrm{C} \quad \mathrm{Fix}=10 \mathrm{~min}$

8. Hold $=22^{\circ} \mathrm{C}$ Exit

Ya que se eligió la temperatura óptima de hibridación de los oligos en PCR mediante un gel de agarosa por electroforesis, observando bandas aisladas y definidas, se prosiguió a realizar nuevamente PCR con dicha temperatura y en mayor volumen para posteriormente purificar a gran escala dicha amplificación. 


\section{Electroforesis en geles de agarosa DNA}

Se siguieron los métodos descritos por Maniatis et al. (1982) y Sambrook et al. (1989). Se utilizó agarosa SeaKem LE (FMC, Ref. 50004) en diferentes concentraciones según fragmentos de DNA a obtener, una concentración de $0.8 \%$ para DNA genómico, 1\% (p/v) para obtener fragmentos de DNA de $0.25-10 \mathrm{~kb}$, y de $1.5 \%$ para fragmentos menores a $1 \mathrm{~kb}$. La agarosa se disolvió por calentamiento con microondas en tampón TAE $1 X^{5}$ durante 1 min y se dejó enfriar, se vació en la base con peine y se dejó solidificar.

Las muestras de DNA (10\%) se mezclaron con un $20 \%$ de tampón de carga ${ }^{6}$ concentrado. Las muestras se cargaron en el gel ya metido en la cámara de electroforesis bañado en tampón TAE $1 X$ y se dejó correr a 80 V durante aproximadamente $50 \mathrm{~min}$. La tinción del ADN se realizó con una solución de bromuro de etidio ${ }^{7}$ (BrEt) en una concentración final de $0.5 \mu \mathrm{g} / \mathrm{mL}$ (el BrEt se intercala en la doble cadena del ADN y permite su visualización tras iluminarse el gel con luz ultravioleta (UV)). Los geles se fotografiaron sobre un Transiluminador ImagenLab de BioRad (emite luz con longitud de onda de $302 \mathrm{~nm}$ ). El marcador de DNA utilizado en los geles de agarosa fue el ADN Ladder (Promega) de 10,000 pb ó 1,000 pb, que contiene fragmentos de ADN individuales purificados.

\section{Purificación de fragmentos DNA}

Se realizó la purificación de sondas y DNAc de genes para qRT-PCR mediante el Kit Wizard SV Gel and PCR Clean-Up System. Se cortó gel con ayuda de navaja y equipo de luz UV identificando el tamaño deseado y se metió en trocitos en tubos epps., se calculó peso del gel, anotando anteriormente peso de tubo vacío y peso con el trocito de gel. Se añadió $10 \mu \mathrm{L}$ de solución de unión a Membrana por cada $0.01 \mathrm{~g}$ de gel. Se agitó con vortex e incubó a $65{ }^{\circ} \mathrm{C}$ hasta disolver gel aprox. $20 \mathrm{~min}$. Se preparó una mini columna dentro de un tubo colector. Se transfirió $800 \mu \mathrm{L}$ de gel disuelto en una mini columna y se incubó 1 min a Ta, se centrifugó 14,000 rpm por 2 min a Ta y se desechó sobrenadante del tubo colector. Se añadió

\footnotetext{
${ }^{5}$ TAE 1X: $57.1 \mathrm{~mL}$ de ácido acético glacial, $100 \mathrm{~mL}$ de EDTA $0.5 \mathrm{M} \mathrm{pH} 8.0,242 \mathrm{~g}$ Tris base y $\mathrm{H}_{2} \mathrm{O}$ dd hasta completar $1 \mathrm{~L}$. Tomar $100 \mathrm{~mL}$ de esta solución y llevar a $5 \mathrm{~L}$ con $\mathrm{H}_{2} \mathrm{O}$ dd.

${ }^{6}$ Tampón de carga 6X: Azul de bromofenol al 0.25\% (p/v), Sacarosa al 40\% (p/v) y Xileno cianol al 0.25\% (p/v). Se esterilizó a $15 \mathrm{lb} / \mathrm{in}^{2}$ durante $20 \mathrm{~min}$. Se conservó a $4^{\circ} \mathrm{C}$.

${ }^{7}$ Bromuro de etidio: Se preparó una solución $10 \mathrm{mg} / \mathrm{mL}$ en agua y se conservó a $4^{\circ} \mathrm{C}$. Para $1 \mathrm{~L}$ de $\mathrm{H}_{2} \mathrm{O}$ dd se requieren $50 \mu \mathrm{L}$ de esta solución.
} 
posteriormente $700 \mu \mathrm{L}$ de solución de lavado, se incubó 1 min a Ta, se centrifugó 14,000 rpm por 2 min a Ta, se hizo otro lavado similar. Se centrifugó con tapa abierta para evaporar etanol restante 1 min. Después se transfirió mini columna a tubo epp. y se añadió $50 \mu \mathrm{L}$ de $\mathrm{H}_{2} \mathrm{O} \mathrm{BM}$, se incubó 1 min a Ta y centrifugó 14,000 rpm por 2 min para obtener DNA purificado, se conservó a $-20^{\circ} \mathrm{C}$.

\section{Secuenciación de fragmentos DNA}

La secuenciación de sondas laeA, lovE y fadA y DNAc para curvas estándares en qRT-PCR (gen fadA, laeA, lovE, atfB, brlA, msnA y lovF) se realizó por el método de terminación de cadena dideoxi de Sanger et al. (1977). Ambas cadenas fueron secuenciadas usando oligos específicos indicados en la Tabla 1.

\section{Transferencia, Marcaje e Hibridación de ácidos nucleicos}

Los soportes más comunes utilizados en la transferencia de ácidos nucleicos son las membranas de nitrocelulosa o de nylon debido a su mayor resistencia. La transferencia a un soporte sólido de fragmentos de DNA obtenidos por digestión con endonucleasas de restricción y sometidos a migración electroforética en un gel de agarosa se denomina "Southern Blot" (Southern, 1975), mientras que la transferencia de moléculas de RNA separadas en un gel de agarosa - formaldehído recibe el nombre "Northern Blot" (Alwine et al., 1977; Thomas, 1980).

El marcaje de la sonda fue realizado con dCTP [a-32P] (3,000Ci/mmol; Amersham) (Readyto-Go DNA labeling beads, Amersham) posteriormente se efectuó la hibridación con membranas (Hybond-Nylon, Amersham) y fueron visualizadas después de la exposición con películas especiales para rayos X (Kodak Sci. Imaging Film X-OMAT-blueXB-1), finalmente escaneadas y analizadas. 


\section{Southern Blot}

Para esta técnica, una vez obtenido el DNA genómico y hecho un análisis de cortes en el DNAman con diferentes enzimas de restricción, se eligieron enzimas que no cortarán dentro de la secuencia de interés, observando ubicación y tamaño, tanto del gen de interés endógeno en parental como del gen exógeno en las construcciones en transformantes. Se procedió a la digestión de DNA genómico en parental y transformantes con enzimas de restricción seleccionadas (BamHI, EcoRV y Ncol) a $37{ }^{\circ} \mathrm{C}$ por 18 h. Este método de digestión, la electroforesis automática realizada con el sistema Avant ABI PRISM 3100 (Hitachi) para correr el DNA genómico (gel de agarosa al $0.8 \%$ por $4 \mathrm{~h}$ con voltaje de $40 \mathrm{~V}$ recirculando TAE $1 \mathrm{X}$ cada hora) y obtención de sonda laeA fueron realizados por métodos estandarizados (Sambrook 1989, Church y Gilbert 1984). La sonda laeA fue amplificado por PCR.

Después de haber tomado imagen del gel con DNA ya corrido, para identificar posición y marcadores, se hizo una depuración ácida, mediante un lavado de 15 min con agitación moderada con $\mathrm{HCl} 0.25 \mathrm{~N}$ y después varios lavados con agua destilada. Posteriormente se desnaturalizo el ADN, sumergiendo el gel en solución de $\mathrm{NaOH} 0.5 \mathrm{M}+\mathrm{NaCl} 1.5 \mathrm{M}$ por 30 min con agitación moderada, enjuagando después con agua destilada. Después se neutralizó el ADN, sumergiéndolo con solución $\mathrm{NaCl} 3 \mathrm{M}$ - Tris- $\mathrm{HCl} 1 \mathrm{M}(\mathrm{pH}$ 7.5) con agitación moderada durante $30 \mathrm{~min}$, se enjuago después con agua destilada. Finalmente se incubó por 20 min en solución SSC $10 X^{8}$.

Para la transferencia se colocó sobre una bandeja limpia dos láminas de papel filtro Whatman 3 MM de tamaño más largo que el gel previamente humedecidas con SSC 10X, a modo que existiera conexión entre el tampón de transferencia a las orillas de la bandeja y el gel. A continuación, se colocó el gel boca abajo y después la membrana de filtro nylon de un tamaño un $\mathrm{cm}$ mayor de anchura y longitud que el gel, posteriormente dos láminas de papel filtro Whatman 3MM del mismo tamaño que el gel y por último un taco de papeles de filtro de las mismas dimensiones que el gel de unos $5 \mathrm{~cm}$ de grosor. Se hizo presión con libros pesados y se dejó aprox. $30 \mathrm{~h}$ la transferencia del DNA a la membrana (Figura 10).

\footnotetext{
${ }^{8}$ Tampón de transferencia: SSC 20X: Citrato trisódico $0.3 \mathrm{M}$ y NaCl $3 \mathrm{M}$. El pH se ajustó a un valor de 7.0 con $\mathrm{HCl}$. Para experimentos con ARN se trató con $0.2 \%$ de DEPC y esterilizó en autoclave.
} 


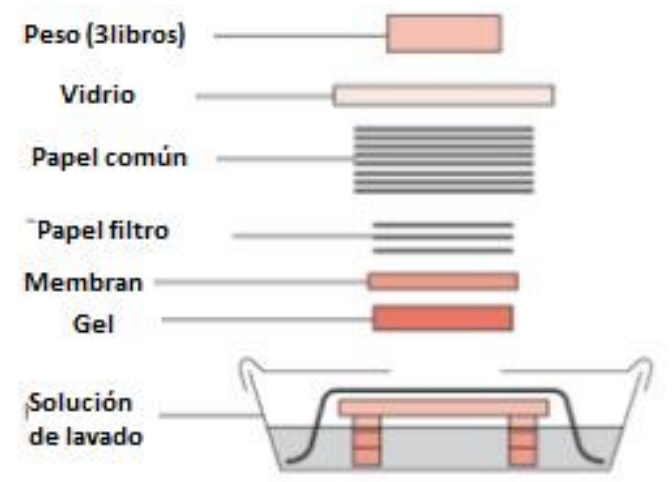

Fig. 10. Proceso de transferencia de ácidos nucleicos.

Después de la transferencia se marcó con lápiz lado correcto y fecha, se fijó membrana con UV mediante Crosslinker UV a $1,200 \times 100 \mu \mathrm{J} / \mathrm{cm}^{2}$ y se marcaron carriles. Se hizo un levantamiento de radiactividad en la zona a trabajar con el detector Geiger y en cada paso se fue monitoreando el buen manejo del isótopo ${ }^{32} \mathrm{P}$. Se encendió el horno de hibridación a 65 ${ }^{\circ} \mathrm{C}, 24 \mathrm{~h}$ antes de utilizarlo. Una vez purificada la sonda, se hizo un control positivo con $5 \mu \mathrm{L}$ en un cuadrito de Hybond y se fijó con luz UV mediante Crosslinker UV a 1,200 X $100 \mu \mathrm{J} / \mathrm{cm}^{2}$. Se preparó una dilución de la sonda con $\mathrm{H}_{2} \mathrm{O}$ BM para tener un volumen de $50 \mu \mathrm{L}$ con $50 \mathrm{ng}$ de ADN totales. Se calentó la sonda diluida $10 \mathrm{~min}$ en ebullición y luego en hielo por $5 \mathrm{~min}$. Se bajó gotitas de la sonda con un pulso en centrífuga. Después se adicionó $45 \mu \mathrm{l}$ de sonda al tubo de marcaje y $5 \mu \mathrm{L}$ de $32 \mathrm{P}$ (marca radiactiva) mezclando suavemente con una punta de pipeta. Se incubó a $37^{\circ} \mathrm{C}$ por 30 min y se mezcló a los 10 min para confirmar que el pellet estuviera disuelto. Para parar la reacción se añadió $175 \mu \mathrm{L}$ de $\mathrm{NaOH} 0.1 \mathrm{M}$ y se dejó dentro de la cámara de protección radiactiva acrílica.

Después se pre-hibridaron membranas y controles metiéndolas en su tubo correspondiente de hibridación y se agregó $10 \mathrm{~mL}$ de $P S E^{9}$, se cerró y metió al horno a girar a $65^{\circ} \mathrm{C}$ por $10 \mathrm{~min}$. Después se retiró el PSE y se adicionó nuevamente $10 \mathrm{~mL}$ de PSE fresco y $225 \mu \mathrm{L}$ de sonda marcada, se cerró bien y se metió a horno girando a $65^{\circ} \mathrm{C}$ por $24 \mathrm{~h}$. Al siguiente día se preparó Solución de lavado ${ }^{10}(\mathrm{SL})$, calculando $200 \mathrm{~mL}$ por tubo. Se sacó un tubo de hibridación con cuidado de no quemarse, se llevó a cámara acrílica ya que está ya está radiactiva y se abrió lentamente, vertiendo líquido con la sonda radiactiva en un tubo falcón sin dejar escurrir y se

\footnotetext{
${ }^{9}$ PSE: Para $200 \mathrm{~mL}$. $60 \mathrm{~mL}$ de fosfato sódico $1 \mathrm{M} \mathrm{pH} 7.2,140 \mathrm{~mL}$ SDS $10 \%$ y $400 \mu \mathrm{L}$ EDTA $0.5 \mathrm{M}$. Se filtro con membrana 0.45 $\mu \mathrm{m}$. Fosfato sódico: Se hicieron $100 \mathrm{~mL}$ con $\mathrm{NaOH} 19 \mathrm{M}$. Se pesó fosfato sódico monobásico para $1 \mathrm{M}$ y se ajustó pH a 7.2 con $\mathrm{NaOH}$ (aprox $50 \mathrm{~mL}$ ).

10 Solución de lavado (SL): Para 1.050 mL: 875 mL de agua, fosfato de sodio 1 M pH 7.2 y SDS $10 \%$. 
guardó a $4^{\circ} \mathrm{C}$ para que decaiga la radiactividad. Al tubo con la membrana y control se le añadió $100 \mathrm{~mL}$ de SL, se cerró bien y se llevó al horno a $65^{\circ} \mathrm{C}$ por $20 \mathrm{~min}$, posteriormente se vertió líquido radiactivo a desechos líquidos y se repitió procedimiento de lavado. Con pinzas largas se sacó la membrana y el control, y se acomodaron en un refractario con poco SL. Después se secaron arrastrándolas en sanitas y se colocó la membrana entre 2 acetatos envolviendo con egapack sellando también orillas. Se midió la radiactividad con el detector Geiger del control para comprobar buena hibridación de la sonda y en la membrana para calcular tiempo de exposición de la película o film, siendo más corto el tiempo de exposición al titiritar el detector muy rápido y constante.

Para la autorradiografía se colocó la membrana entre dos acetatos sellándolo en orillas con masking y se colocó dentro de un cassette con pantalla intensificadora. En un cuarto oscuro, se colocó la película, dándole un doblez para asegurar posición en el cassette. Se cerró el cassette y se guardó dentro de una bolsa negra, se llevó a $-75{ }^{\circ} \mathrm{C}$ durante el tiempo ya calculado al usar el detector Geiger. En el revelado se llevó el cassette al cuarto oscuro, se sacó la película y se dejó en solución reveladora 2 min, en agua una pasada, en solución fijadora $5 \mathrm{~min}$, y en agua de 5 a $10 \mathrm{~min}$, se encendió luz y se colgaron las películas para su secado y posterior análisis.

\section{Northern Blot}

Para realizar esta técnica, se efectuó la obtención de sondas con DNA genómico de los genes laeA, lovE y fadA de 364 pb, 585 pb y 436 pb respectivamente. Se prosiguió a la obtención y purificación de RNA total y se corrió en un gel de agarosa - formaldehído. Para $200 \mathrm{~mL}$ de agarosa fundida, se pesó $2.4 \mathrm{~g}$ de agarosa en $174 \mathrm{~mL}$ de $\mathrm{H}_{2} \mathrm{O}$ desionizada, se fundió agarosa 2 min en horno de microondas, se dejó enfriar un poco y una vez estando a $50-55^{\circ} \mathrm{C}$ se agregó $20 \mathrm{~mL}$ de MAE $10 \mathrm{X}^{11}$ y $6 \mathrm{~mL}$ de formaldehído, se mezcló bien y se vació en base para formar el gel. Para correr muestras se agregó $10 \%$ de tampón de carga para RNA en todas las muestras y se corrió gel a $80 \mathrm{~V}$ por 2 h. Después de haber tomado imagen en foto documentador del gel con RNA ya corrido para identificar posición y marcadores, se prosiguió a la transferencia, marcaje y revelado, siendo similar a lo realizado en Southern Blot.

\footnotetext{
${ }^{11}$ MAE 10X: MOPS $0.2 \mathrm{M}$, acetato sódico $50 \mathrm{mM}$ y EDTA $10 \mathrm{mM}$, ajustando a pH 7 con $\mathrm{NaOH}$.
} 


\section{qRT - PCR (PCR tiempo real)}

Se sugirió diseñar los oligos para el qRT-PCR en los extremos del exón del gen de interés donde haya un intrón de por medio, donde se obtuviera un tamaño del fragmento amplificado con base de RNA y transcriptasa reversa no mayor a 200 pb. Así, si existe contaminación por DNA, el fragmento formado será mayor a 200 pb, por la amplificación del intrón, tal como se muestra en la Figura 11, por lo que se purificó muy bien el RNA con RQ1 RNase-Free DNAse y se descartó contaminación haciendo PCR normal con Go Taq Colorless Máster Mix, en gel de agarosa al $1.5 \%$ y con marcador de $1,000 \mathrm{pb}$.

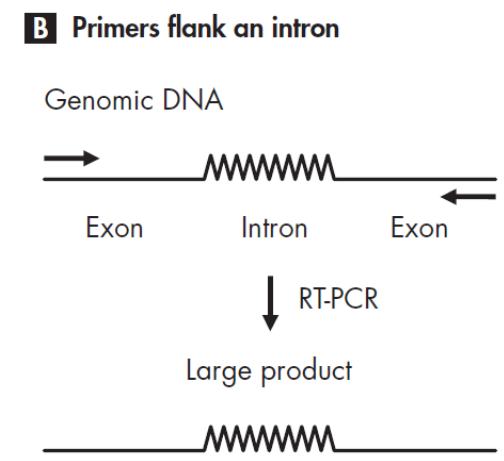

Fig. 11. Fragmento de RNA amplificado y contaminado por DNA.

Una vez obtenida la temperatura óptima de anillamiento de oligos de cada gen de interés (gen fadA, laeA, lovE, atfB, brlA, msnA y lov $F$ ) y del gen control endógeno o house keeping gen hkg (gen como control endógeno para calibración de muestras, gen factor de elongación $E F$ ) con el Kit Express One Step RT-PCR y RNA de parental como templado, usando el diseño de los oligos descritos en la Tabla 1, se verificó la limpieza de sólo una banda obtenida (DNAc) para evitar contaminación y ruido en qRT-PCR, después se procedió a obtener fragmentos a gran escala con el Kit Go Taq Colorless Master Mix, purificarlos para secuenciar y comprobar su identificación, y finalmente utilizarlos como curvas estándar en el qRT-PCR, cuantificando previamente su concentración. Se prosiguió con el establecimiento de rangos de la curva estándar de cada gen de interés y del hkg con el Kit EXPRESS One-Step SYBR® GreenER ${ }^{\text {TM }}$ qRT-PCR Universal. Después de obtener el RNA total de cada muestra y descartar contaminación de DNA, se cuantificó la concentración de RNA total y se estandarizaron a 20 $\mathrm{ng} / \mu \mathrm{L}$ por gel electroforético y Nanodrop 2000. Finalmente se hicieron corridas de cada gen de interés con las diferentes muestras por triplicado usando 40 ng de RNA total como lo recomienda el Kit. El ciclo térmico para activación de transcriptasa reversa fue de $50{ }^{\circ} \mathrm{C}$ por 
30 min, para la activación de HotStar Taq Polimerasa de $95^{\circ} \mathrm{C}$ por $2 \mathrm{~min}$, la temperatura de alineación de $60^{\circ} \mathrm{C}$ por $50 \mathrm{seg}$, por 40 ciclos. Los valores normalizados fueron obtenidos para tener un efecto real y no efecto de carga, como una fracción de la concentración obtenida de cada gen de interés y la concentración del gen control endógeno bajo las mismas condiciones obteniendo así la expresión absoluta de cada gen.

\section{CARACTERIZACIÓN DE TRANSFORMANTES}

\section{Preselección y Selección de mejores transformantes}

Las transformantes con alta producción de lovastatina fueron preseleccionadas por fermentación en cilindro de agar y bioensayo con Neurospora crassa según Kumar et al. (2000), confirmando que la transformante con plásmido sin inserto (control) tenía producción similar a parental. Se preseleccionaron 10 transformantes de cada estrategia (Pérez et al., 2015). Posteriormente se efectuó el análisis para la selección de las mejores transformantes en FS y FL, evaluando producción de lovastatina al día 7. Después las mejores transformantes de ambos sistemas de cultivo: T1laeA, T9laeA, T2laeAcons yT5laeAcons, que SE::laeA, fueron caracterizadas realizando cinéticas de producción, Southern Blot y PCR para confirmar la integración de construcciones respectivas y qRT-PCR para confirmar SE::/aeA.

\section{Análisis de parámetros fisiológicos}

Se analizaron otros parámetros fisiológicos como esporulación, crecimiento radial, resistencia a estrés y morfología en parental y varias transformantes de cada estrategia. Para las transformantes que expresan laeA con su propio promotor (pUAMTPlaeA), se analizó la: T1, T4, T9, T12, T13, T14, T15 y T16laeA, mientras que transformantes que expresan laeA constitutivamente (pUAMTPlaeAcons), se analizó la: T2, T5, T6, T7, T8, T9 y T10laeAcons. Para analizar la esporulación se creció un inóculo de $10^{5} \mathrm{esp} / \mathrm{mL}$, en $25 \mathrm{~mL}$ de medio Papa Dextrosa Agar (PDA) y se incubó por $4 \mathrm{~d}$. Para crecimiento radial se inoculó $10^{3} \mathrm{esp} / \mathrm{mL}$, en placas con PDA y se incubó por $7 \mathrm{~d}$, se midió diámetro de colonia. Para estrés oxidativo, se inoculo $10^{4} \mathrm{esp} / \mathrm{mL}$ con $140 \mathrm{mM}$ de $\mathrm{H}_{2} \mathrm{O}_{2}$, se sembró en placas PDA e incubó por $4 \mathrm{~d}$, y para estrés osmótico, se inoculo $10^{4} \mathrm{esp} / \mathrm{mL}$ en placas PDA con $2.9 \mathrm{M} \mathrm{de} \mathrm{NaCl}$ por $3 \mathrm{~d}$. Para analizar morfología solo se dejó crecer un inoculó $10^{5} \mathrm{esp} / \mathrm{mL}$, en $25 \mathrm{~mL}$ de medio Power y se incubó por $5 \mathrm{~d}$. Todas las muestras incubadas a $30^{\circ} \mathrm{C}$, realizadas por triplicado. 


\section{RESULTADOS}

\section{Análisis de parámetros fisiológicos}

\section{Producción de lovastatina en FS y FL}

Se realizó FS y FL de lovastatina con $A$. terreus TUB F-514, una cepa silvestre con alta producción de lovastatina. En esta primera parte, la FS y FL se llevaron a cabo utilizando un medio complejo de tipo industrial.

En ambos sistemas de cultivo, la producción de lovastatina comenzó, aproximadamente a la misma hora (alrededor de $24 \mathrm{~h}$ ) y continuó hasta el día 9. Se puede observar en la Figura 12A y $12 \mathrm{~B}$ que, al día 7, la producción del metabolito fue mucho mayor en FS respecto a la FL (15.45 mg /gss vs $0.43 \mathrm{mg} / \mathrm{mL}$ ). Por otro lado, la producción específica al día 5, fue 9 veces mayor en la FS respecto a la FL (Figura 13). Es importante tener en cuenta que la cinética de $\mathrm{pH}$ fue similar en ambos sistemas de cultivo (Figura 12a y 12b). Esta producción de lovastatina superior en FS respecto a la FL, es parte de lo que se ha llamado en artículos recientes como fisiología del medio sólido.
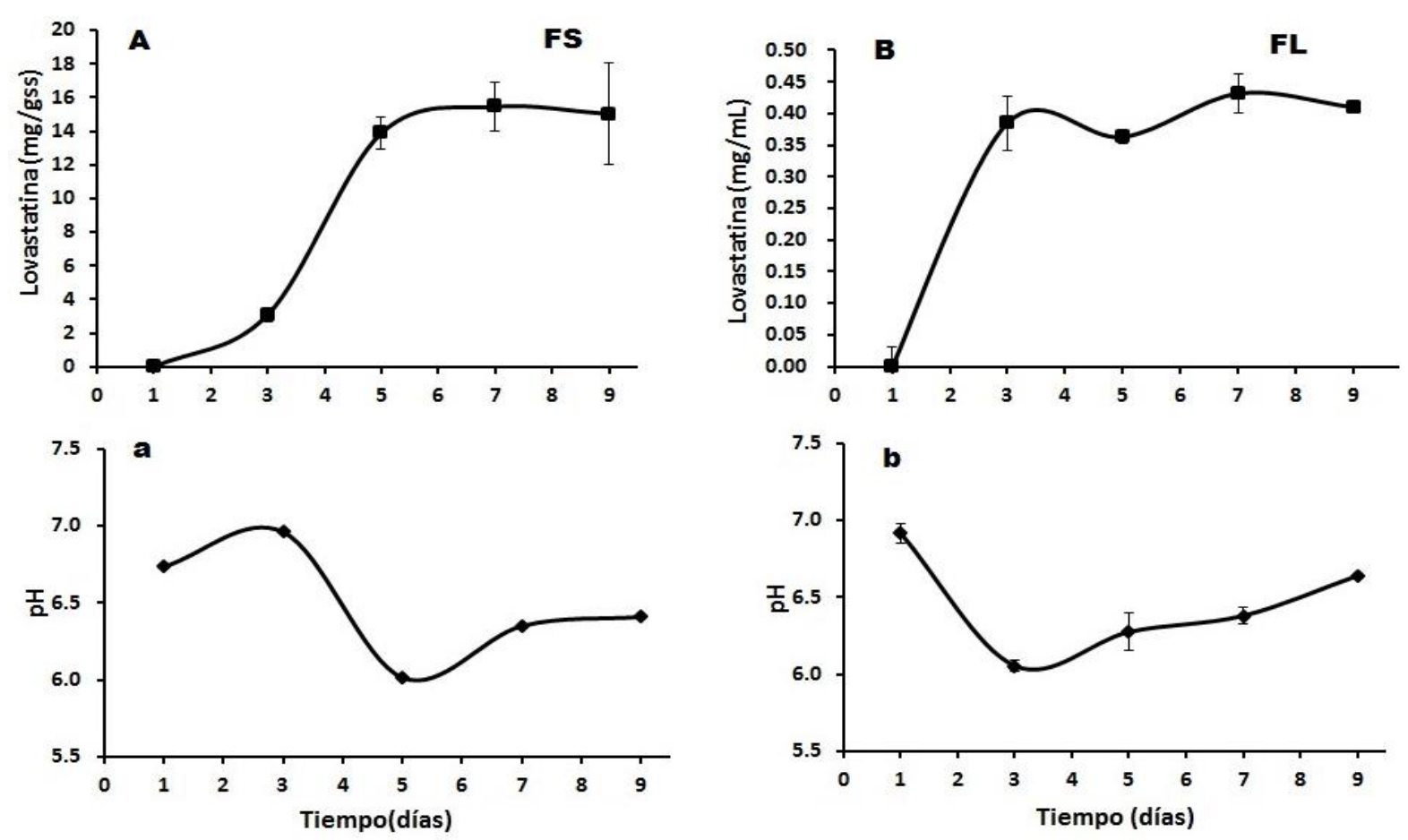

Fig. 12. Producción de lovastatina en FS (11A) y FL (11B). pH en FS (11a) y FL (11b) de parental. 


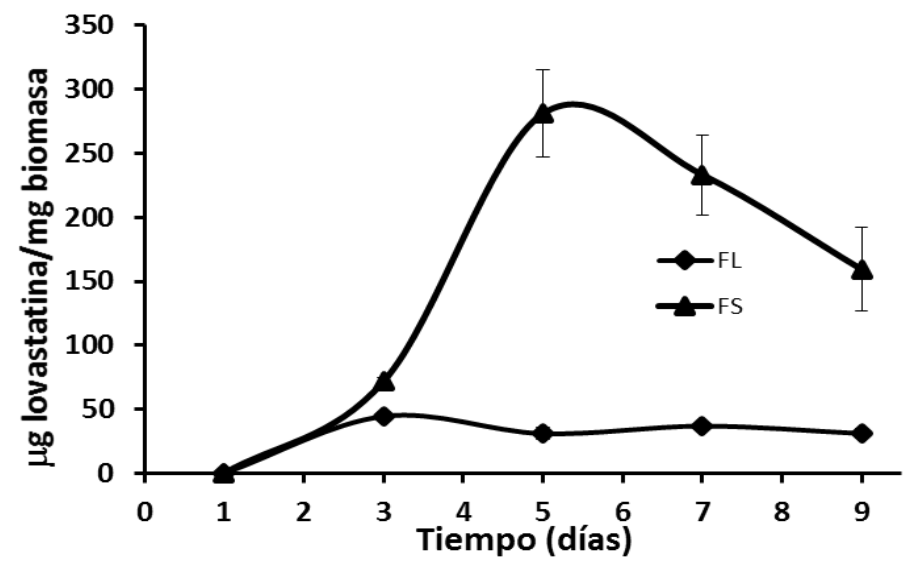

Fig. 13. Producción específica de lovastatina en FS $(\stackrel{-}{-})$ y FL $(\stackrel{-)}{\circ)}$

\section{Estudio de componentes principales de la vía AMPc-PKA}

\section{Perfiles de expresión de genes fadA, laeA y lovE}

Con la idea de que la expresión de fadA puede ser proporcional a su participación en la señalización, i.e. mayor cuando la subunidad a (FadA) está activada, y para ver si en $A$. terreus, FadA está relacionada con la producción de este MS y con la esporulación, se estudió la expresión del gen fadA. Se comparó su expresión con la expresión de genes blancos putativos, corriente abajo en la vía de señalización.

El patrón de expresión de fadA se analizó en FS y FL, observando expresión diferencial en ambos sistemas de cultivo. Se realizó Northern Blot y RT-PCR dando resultados más o menos comparables. Como se observa en la Figura 14A, en FS, la expresión de fadA fue relativamente baja y constante, con un posible incremento a las $21 \mathrm{~h}$ (aunque la carga de RNA es mayor también). En FL, la expresión de fadA fue alta en trofofase (16 y $18 \mathrm{~h}$ ) y baja a las $21 \mathrm{~h}$, llegando a ser constante y baja durante la idiofase. Se puede decir que en la trofofase, el comportamiento en la expresión de fadA en FL, fue ligeramente inverso al observado en la FS, no obstante, en la idiofase el comportamiento en FS y FL fue similar, siendo en ambos sistemas de cultivo, regulada negativamente la expresión de fadA.

También se estudió a detalle la expresión de laeA, el gen regulador global de metabolitos secundarios, durante la FS y FL, en cepa parental. Como se observa en Figura 14B, en ambos 
sistemas de cultivo, la expresión de laeA fue mucho mayor en trofofase, y en particular en ciertos tiempos ( $21 \mathrm{~h}$ en FS y toda la trofofase en FL). Después bajo significativamente en la idiofase, llegando a observarse casi nula a 72 h (en Northern, sin embargo, en RT-PCR si se observó una expresión moderada). En general, se observó una expresión ligeramente mayor de lae $A$ en FL que en FS en la trofofase. La tendencia del perfil de expresión de laeA se observó similar al perfil observado en la expresión de fadA (Figura 14A), (i.e. más alta expresión en trofofase y menor en idiofase).

Es interesante resaltar que se observó una alta expresión de laeA al final de la trofofase, en ambos sistemas de cultivo, lo cual coincide con el posterior encendido del gen lovE y el inicio de la producción del metabolito secundario (lovastatina), sugiriendo la activación de estos mecanismos regulados por LaeA. Sin embargo, después se observó que esta expresión de laeA en idiofase fue regulada negativamente, al hallarse casi nula la expresión de la misma. Lo anterior sugiere una relación estrecha y positiva de FadA con el gen laeA o viceversa.

Es interesante notar que se esperaba un comportamiento similar entre la expresión de laeA y lovE (factor de transcripción específico de lovastatina); sin embargo, no fue lo que se obtuvo. Lo que observamos en la Figura 14C, fue una expresión lógica de lovE sólo a niveles altos en la idiofase (42 y $72 \mathrm{~h}$ ) en ambos sistemas de cultivo y un poco a las $21 \mathrm{~h}$ en FL. En general, la expresión de lovE se observó inversa a la expresión de laeA.

El patrón de expresión de fadA también fue comparado con la expresión de lovE. En ambos sistemas de cultivo, la expresión de lovE fue alta sólo en idiofase, cuando fue regulada negativamente la expresión de fadA. Esto indica una relación de regulación negativa de FadA hacía lovE. 

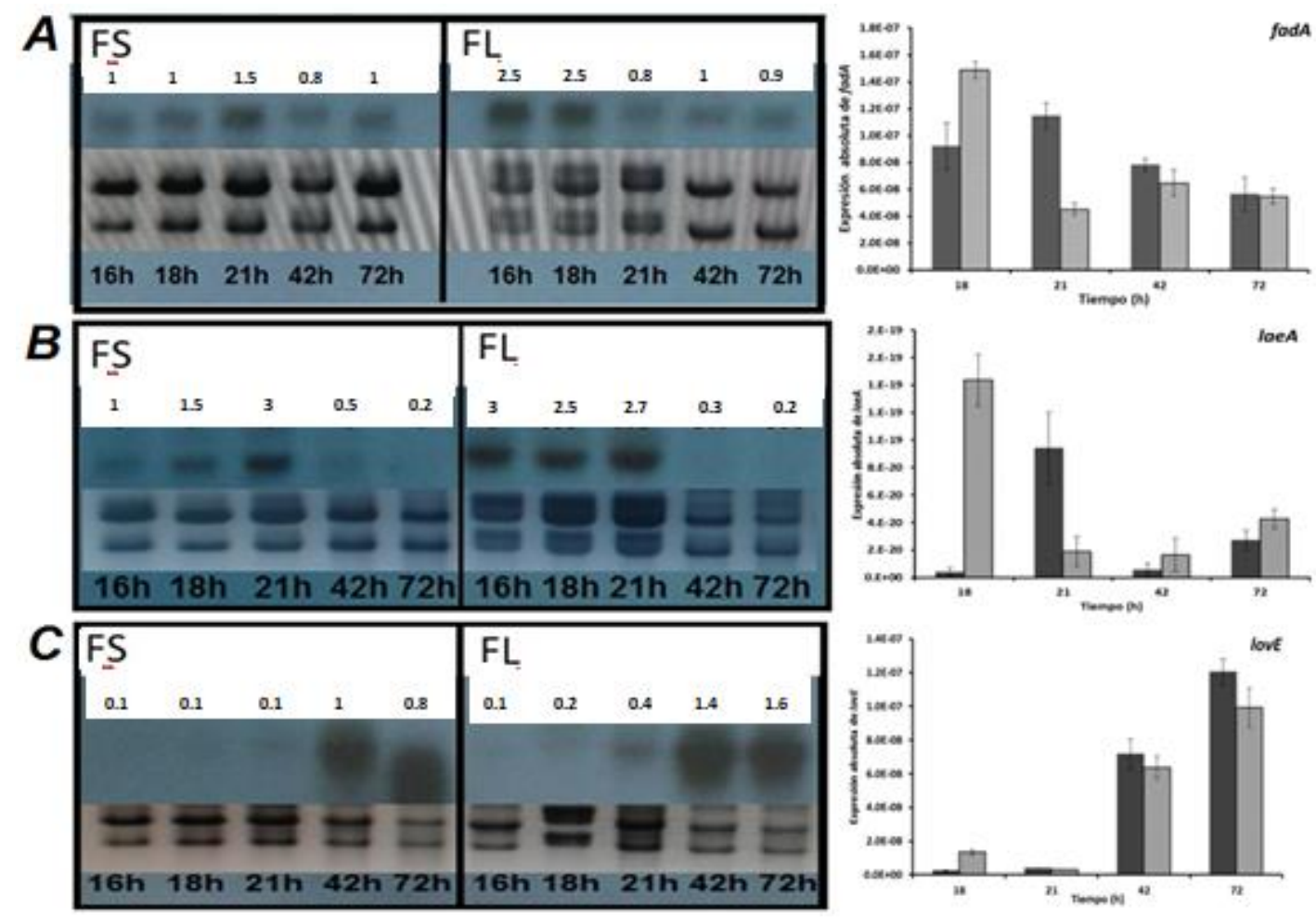

Fig. 14. Northern Blot y expresión absoluta de genes: $\operatorname{fad} A(\boldsymbol{A}), \operatorname{lae} A(\boldsymbol{B})$ y lovE $(\boldsymbol{C})$ en FS ( $\square$ ) y FL ( $)$ de cepa parental.

\section{Concentración de AMPc y expresión de fadA en FS y FL}

Para saber si hay una relación entre la expresión de $\operatorname{fad} A$ y $A M P c$, se determinó la concentración de este segundo mensajero durante la FS y FL de lovastatina.

Generalmente, los resultados mostraron una relación contraria entre la expresión de fadA y la concentración de AMPc en ambos sistemas de cultivo. La expresión de fadA fue más alta en trofofase (más en FL) y baja en idiofase, en ambos sistemas de cultivo, mientras que el perfil de AMPc encontrado fue inversamente proporcional.

Resumiendo, En FL, cuando la expresión de fadA a las 18h fue alta, la concentración del AMPc fue baja, después a las $21 \mathrm{~h}$ en adelante la expresión de fadA tendió a la baja, mientras que la concentración del AMPc fue al alta. Sin embargo, en FS donde la expresión de fadA fue relativamente baja y constante en todos los tiempos analizados (excepto a las $21 \mathrm{~h}$ ), se observó una concentración alta de AMPc en trofofase (sólo a las 18 h) y una drástica bajada desde las $21 \mathrm{~h}$, tendiendo a subir muy ligeramente en idiofase a las $42 \mathrm{~h}$ (Figura 15). 


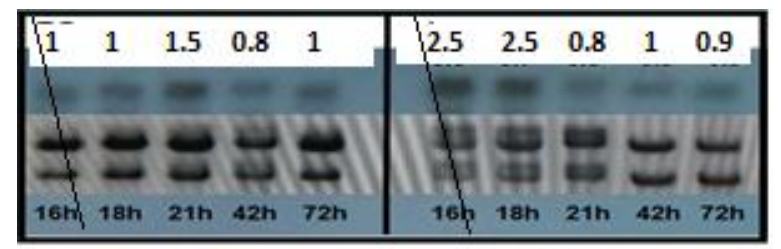

FS

$\mathrm{FL}$

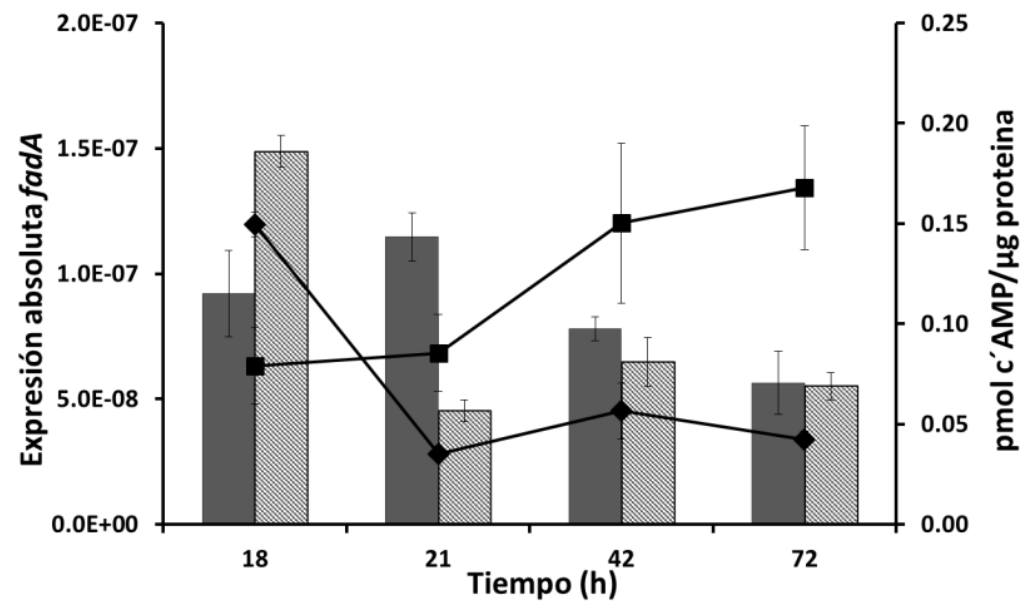

Fig. 15. Northern Blot y expresión absoluta de fadA en FS ( $\square$ ) y FL ( Concentración de AMPc en FS (-๑) y FL $(-\mathbf{-})$ ) de cepa parental.

\section{Actividad específica PKA en FS y FL}

Los resultados mostraron una relación directa entre la actividad específica PKA y la concentración de AMPc en ambos sistemas de cultivo, siendo muy similar el comportamiento de ambos componentes en cada fase de crecimiento para cada sistema de cultivo, aunque con magnitudes muy distintas.

En FS, se encontró una alta actividad específica PKA en trofofase (18 h) la cual cae drásticamente a las $21 \mathrm{~h}$ y se mantiene casi constante hasta la idiofase (42 y $72 \mathrm{~h}$ ), esto en concordancia con la concentración de AMPc, ya antes descrita. Mientras que en FL, hubo una baja actividad específica PKA a las $18 \mathrm{~h}$ (mucho más baja que la observada en FS), se mantuvo a las $21 \mathrm{~h}$ y subió en idiofase (42 y $72 \mathrm{~h}$ ), al igual que lo observado con la concentración de AMPc. La actividad específica PKA en la idiofase se observó sin diferencia en ambos sistemas de cultivo. Es importante notar que, en la trofofase, la actividad específica PKA en FS fue mucho mayor a la encontrada en FL (más a las 18 h). 


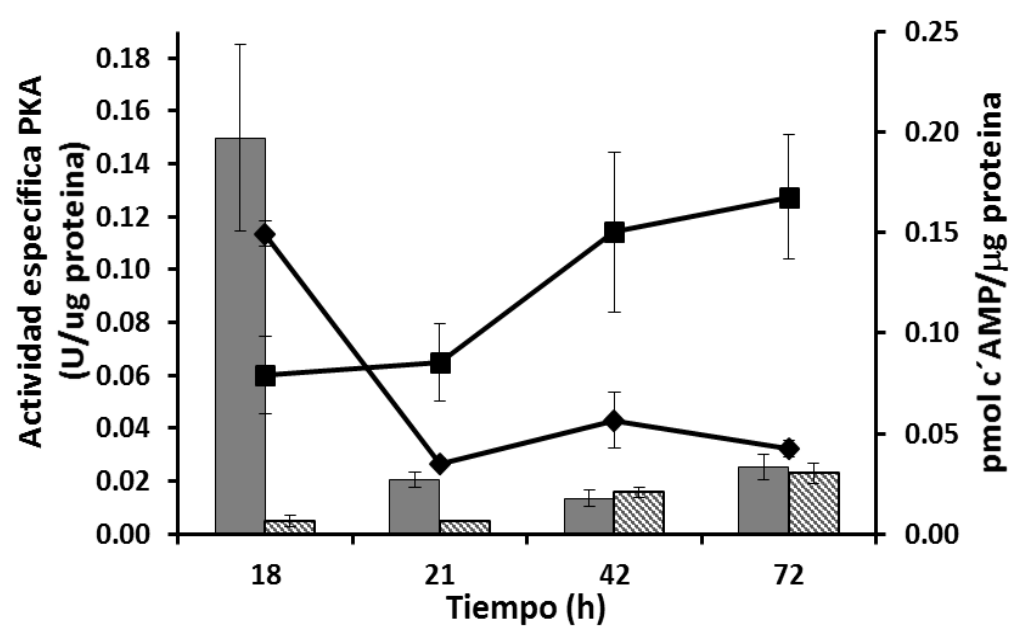

Fig. 16. Actividad específica PKA en FS ( $\square$ ) y FL ( Concentración de AMPc en FS ( $\bullet-)$ y FL $\left(-\boldsymbol{m}^{-}\right)$de cepa parental.

\section{Otros componentes reguladores de la vía AMPc-PKA}

Perfiles de expresión de otros genes involucrados en la vía: lovE, lov $F$, brlA, msnA y atfB.

Ya se había comentado anteriormente un comportamiento similar de la expresión de fadA y laeA en ambos sistemas de cultivo. Por otra parte, la expresión de lovE y lovF (casi nulo en trofofase y alto en idiofase en ambos sistemas de cultivo, más en la FS) también tuvo un comportamiento similar, algo que era de esperarse, pues están estrechamente relacionados al codificar lov $F$ una policétido sintasa del clúster biosintético de biosíntesis de lovastatina, observándose una clara relación positiva de ambos genes (Figura 17), pero sus perfiles de expresión de ambos genes fueron opuestos con la expresión de fadA y laeA.

En la misma Figura, otro factor involucrado e importante en la vía, es el factor de transcripción de la conidiación, brIA. Como era esperado, éste se expresó solamente en FS, claramente a las $72 \mathrm{~h}$ en la idiofase, lo que es lógico, ya que se observaron sólo esporas en FS después de $72 \mathrm{~h}$.

Referente a otros transcritos involucrados no tan directamente pero que convergen en la vía AMPc-PKA, está el gen atfB y $m s n A$, éstos en la Figura 17, mostraron comportamientos muy diferentes. En relación con el gen atfB, su expresión fue mayor en FS que en FL. En FS, su expresión en trofofase fue significativamente más alta que en idiofase donde fue regulado a la 
baja. Mientras, en la FL también fue alta en trofofase, aunque sólo a las $18 \mathrm{~h}$ y no tanto como en la FL; después bajo a las $21 \mathrm{~h}$, manteniéndose casi constante hasta $72 \mathrm{~h}$. Con este comportamiento pareciera que FadA está influenciando de manera positiva la expresión de atfB. Sobre la acumulación del transcrito $m s n A$, factor transcripcional de respuesta al estrés, fue más elevado en idiofase que en trofofase, en ambos sistemas de cultivo. En FS, los niveles del transcrito fueron muy bajos de las $18 \mathrm{~h}$ a las $42 \mathrm{~h}$ y subió significativamente a las $72 \mathrm{~h}$. Mientras que en FL, fue relativamente alto en $18 \mathrm{~h}$, bajo a las $21 \mathrm{~h}$ y subió significativamente a las $42 \mathrm{~h}$ bajando nuevamente a $72 \mathrm{~h}$. Pareciera que LaeA influye de manera negativa en la expresión de $m s n A$.

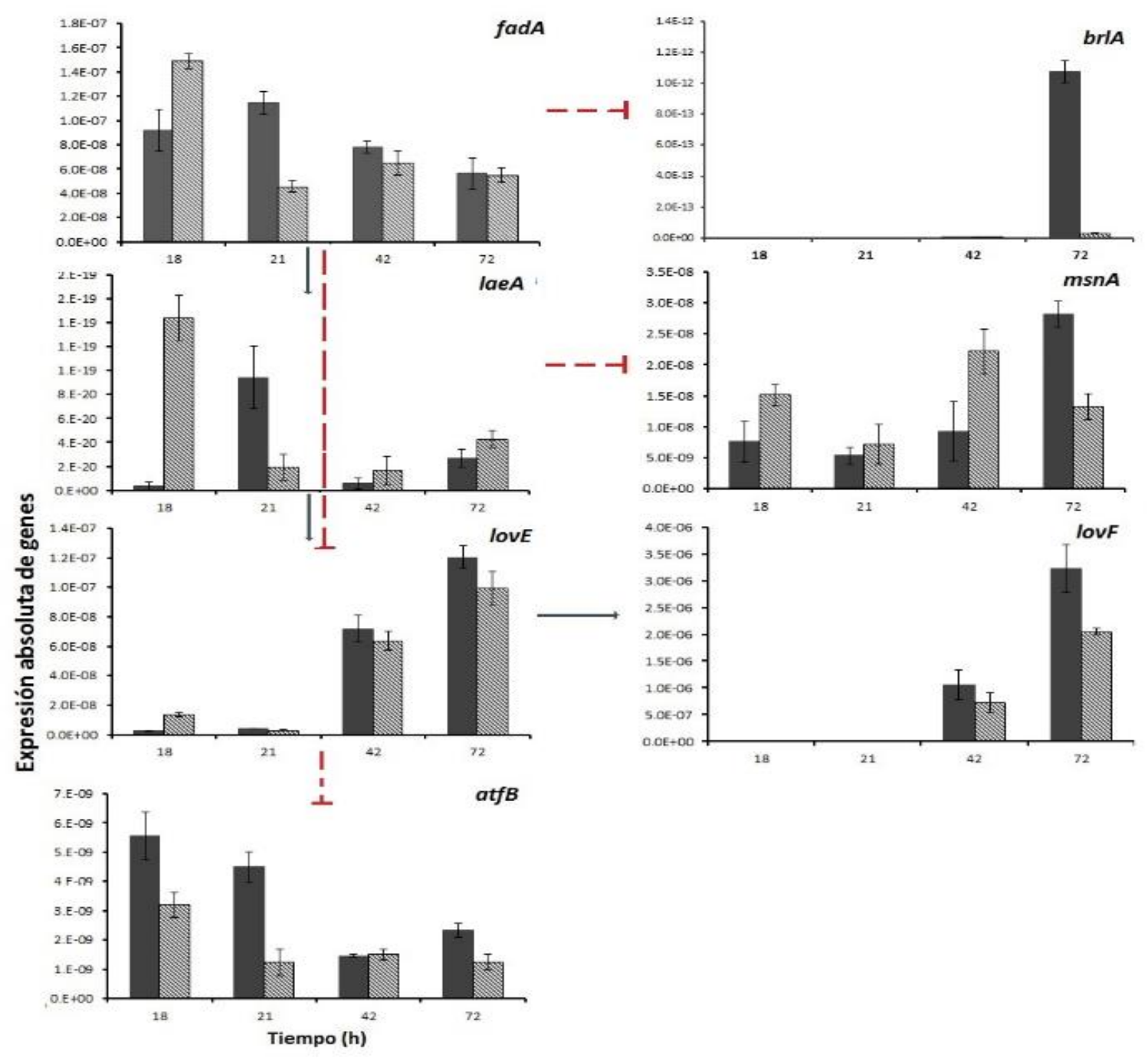

Fig. 17. Expresión absoluta de genes: fadA, laeA, lovE, atfB, brlA, $m n s A$ y lovF en $\mathrm{FS}(\square)$ y FL ( $)$ de cepa parental en RT-PCR. 
Se muestra en la Tabla 2, una visión general de los componentes de la vía AMPc-PKA estudiados y previamente analizados a detalle, durante la FS y FL de lovastatina: concentración de AMPc, Actividad PKA y expresión de genes fadA, laeA, lovE, lov , brlA, $m s n A$ y atfB.

Tabla 2. Visión general de expresión de genes relacionados con la vía AMPc-PKA y concentración de AMPc y actividad PKA, durante la FS y FL de lovastatina. Poca $\left({ }^{*}\right)$, mediana $\left({ }^{* *}\right)$ o alta $\left({ }^{* * *}\right)$ expresión de genes, cuantificación de AMPc 0 actividad de PKA.

\begin{tabular}{|c|c|c|c|c|}
\hline Componente & Trofofase & Idiofase & $\begin{array}{c}\text { Comentario } \\
\text { FS vs FL }\end{array}$ & Otros \\
\hline fadA & *** & * & $\begin{array}{l}\text { Más notoria la } \\
\text { diferencia en FL }\end{array}$ & \\
\hline \multirow[t]{2}{*}{ AMPc } & FS **** & * & & \\
\hline & FL $\quad *$ & ***** & & \\
\hline \multirow[t]{2}{*}{ PKA } & FS **** & * & & \\
\hline & $\mathrm{FL} \quad *$ & *** & & \\
\hline laeA & **** & * & $\begin{array}{l}\text { FS pico } 21 \mathrm{~h} \\
\text { FL pico } 18 \mathrm{~h}\end{array}$ & $\begin{array}{l}\text { Sube un poco } \\
\text { a las } 72 \mathrm{~h}\end{array}$ \\
\hline$a t f B$ & **** & * & & \\
\hline$m s n A$ & & $* *$ & Sobre todo FS & $72 \mathrm{~h}$ \\
\hline brlA & & ***** & Sólo en FS & $72 \mathrm{~h}$ \\
\hline lovE, lovF & & ***** & Más intenso FS & Inicia $42 \mathrm{~h}$ \\
\hline
\end{tabular}

Se puede observar en nuestro análisis, se da el inicio del funcionamiento de la vía AMPc-PKA indirectamente mediante la expresión de $\operatorname{fad} A$, siendo menos notoria dicha expresión en FS, sobre todo en la trofofase, donde se aprecia mayor concentración de AMPc y actividad específica PKA (siendo estos mismos bajos en $\mathrm{FL}$ ), además, mayor expresión de laeA y atfB en ambos sistemas de cultivo. Por el contrario, en idiofase, cuando la expresión de fadA fue regulada negativamente (en ambos sistemas de cultivo) los comportamientos de la concentración de AMPc y actividad específica PKA son inversos tanto en FS como en FL, y la expresión de laeA y atfB tienden igual a ser regulados de forma negativa, observándose mayor expresión de los genes $m s n A$, brIA, lovE y lovF, siendo más intenso en FS. 


\section{Análisis in sílico de promotores fadA, lovE y laeA}

En la Tabla 3 se muestra el análisis de los promotores de los genes fadA, lovE y laeA, encontrando sitios teóricos putativos de unión de factores de transcripción relacionados con el desarrollo (ASH1, SOK2, MOT3), respuestas ambientales (ROX1, YAP1, ZMS1) y respuesta general de estrés (MSN2, MSN4, CUP9, ZMS1) mediante la base de datos JASPAR obtenido de la colección ampliada del modelo Saccharomyces cerevisae.

Tabla 3. Análisis in sílico de promotores fadA, lovE y laeA.

\begin{tabular}{|c|c|}
\hline FACTOR DE TRANSCRIPCIÓN & $\begin{array}{c}\text { NÚM. VECES DE UNIÓN EN } \\
\text { PROMOTOR }\end{array}$ \\
\hline DESARROLLO: & lovE: $6 ;$ laeA: $8 ;$ fadA: 3 \\
\hline ASH1 & lovE: 57 ; laeA: $35 ;$ fadA: 24 \\
\hline MOT3 & \\
\hline RESPUESTA AMBIENTAL: & lovE: $0 ;$ laeA: $0 ;$ fadA: 2 \\
\hline ROX1 & lovE: $2 ;$ laeA: $4 ;$ fadA: 0 \\
\hline ZMS1 & \\
\hline RESPUESTA ESTRÉS: & lovE: $28 ;$ laeA: $17 ;$ fadA: 8 \\
\hline MSN2/4 & lovE: $7 ;$ laeA: $4 ;$ fadA: 8 \\
\hline
\end{tabular}

\section{Caracterización de transformantes con SE::laeA}

\section{Obtención de construcciones pUAMTPlaeA y pUAMTPlaeAcons}

Para determinar el efecto de la sobreexpresión del gen laeA (SE::/aeA) se diseñaron 2 construcciones, expresando laeA bajo su propio promotor y bajo un promotor constitutivo. El esquema $1 \mathrm{~A}$ muestra la construcción pUAMTPlaeA, que se obtuvo al clonar el ADN correspondiente al gen lae $A$ con su propio promotor y terminador (tamaño $2.6 \mathrm{kbp}$ ), en el sitio $B a m H I$ del plásmido pULC43. El esquema 1B muestra la construcción pUAMTPlaeAcons, que se obtuvo clonando de manera direccional sólo la secuencia que codifica el gen laeA (tamaño $1.25 \mathrm{kbp}$ ) en el sitio $\mathrm{Ncol}$ y $\mathrm{BamHI}$ del plásmido pAN52.1, el cual contiene, un promotor de expresión constitutiva del gen gpd de $A$. nidulans y terminador de trpC. Las construcciones obtenidas se transformaron en $A$. terreus (Pérez et al., 2015). 
Esquema 1. A) Clonación del gen completo laeA en plásmido pULC43 obteniendo la construcción pUAMTPlaeA.

B) Clonación de la secuencia codificadora del gen laeA en plásmido pAN52.1 obteniendo la construcción pUAMTPlaeAcons.
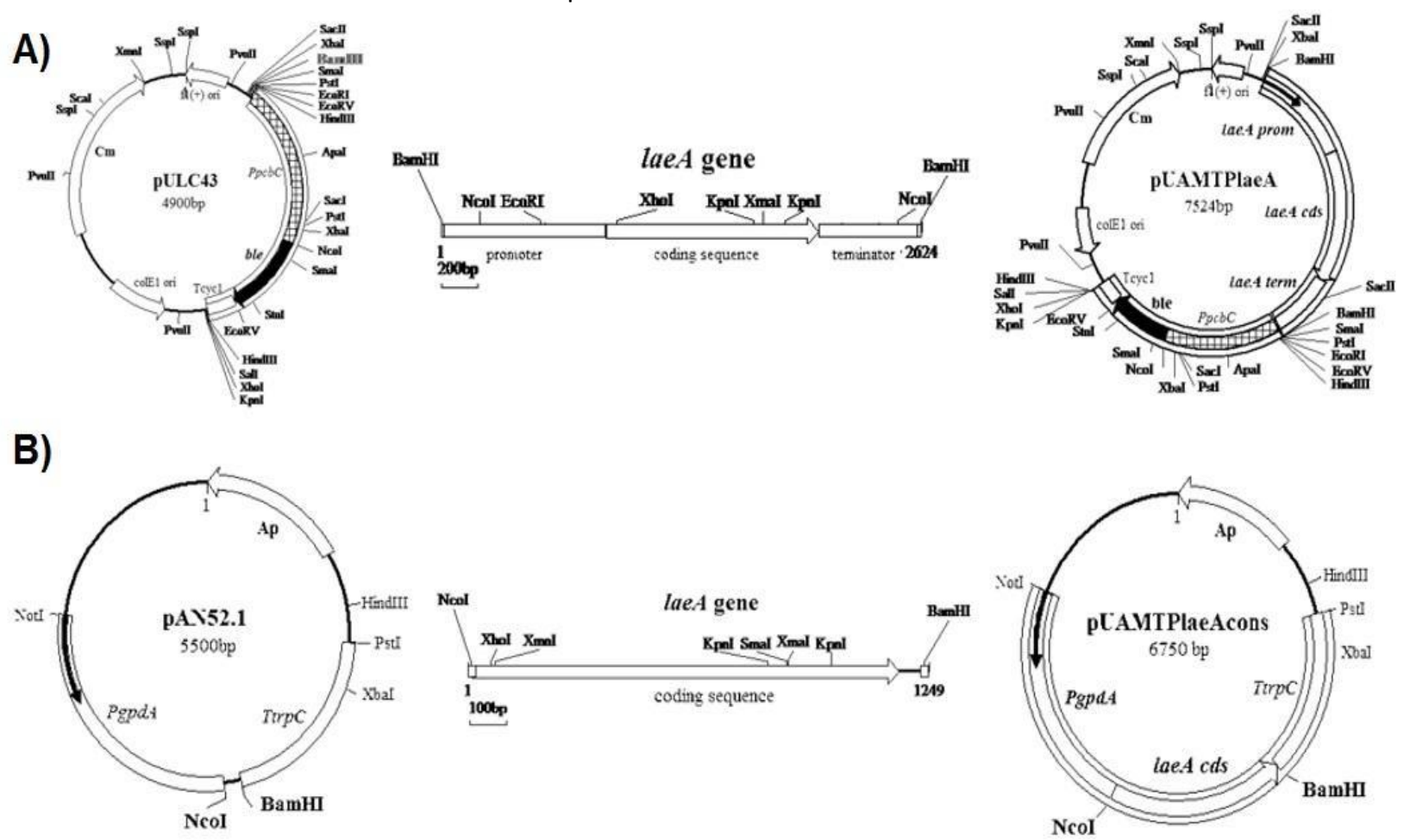

\section{Selección de transformantes de $A$. terreus}

Los protoplastos de $A$. terreus TUB-514 se transformaron con la construcción pUAMTPlaeA y pUAMTPlaeAcons independientemente, para obtener transformantes que sobreexpresan lae $A$ con su propio promotor y bajo un promotor constitutivo (SE::/aeA).

Transformantes LaeA con promotor propio. La primera estrategia basada en la construcción pUAMTPlaeA, expresando el gen laeA con su propio promotor, resultó en la obtención de 21 transformantes resistentes a fleomicina $(120 \mu \mathrm{g} / \mathrm{mL})$, las cuales fueron evaluadas inicialmente en cuanto a su producción de lovastatina en fermentación en cilindro de agar (FCA), tratando de disminuir la población eliminando falsas transformantes o transformantes que integraron el vector en sitio no conveniente. De esta población, 10 transformantes mostraron la mayor producción de lovastatina respecto a la parental ( $>220 \mu \mathrm{g} \operatorname{lov} / \mathrm{mL} v s 190 \mu \mathrm{g} \mathrm{lov} / \mathrm{mL}$, respectivamente) y se continuó su caracterización (Pérez et al., 2015). 
Al evaluarse la producción de lovastatina de las 10 transformantes en FS y FL (al día 7), se muestra en la Tabla 4, que el 90\% fueron sobreproductoras de lovastatina en FS (con rango del 11 a $47 \%$ de incremento, respecto a la parental), siendo la T9laeA, la mejor productora con un incremento del $47 \%$. Mientras que el $50 \%$ de las transformantes evaluadas, fueron sobreproductoras de lovastatina en FL (con rango del 5 a $82 \%$ de incremento), siendo la T1laeA, la mejor productora con un incremento del $82 \%$, respecto a la parental.

Tabla 4. Producción de lovastatina de Transformantes con construcción pUAMTPlaeA en FS y FL (7d).

\begin{tabular}{|c|c|c|}
\hline $\begin{array}{c}\text { Transformantes } \\
\text { pUAMTPlaeA }\end{array}$ & $\begin{array}{c}\text { FS: Producción } \\
\text { Lovastatina } \\
\text { (mg/gss) }\end{array}$ & $\begin{array}{c}\text { FL: Producción } \\
\text { Lovastatina } \\
(\mathrm{mg} / \mathrm{mL} \text { ) }\end{array}$ \\
\hline Parental & $15.3 \pm 0.75^{\mathrm{a}, \mathrm{b}}$ & $0.44 \pm 0.05^{\mathrm{b}, \mathrm{c}}$ \\
\hline T9laeA & $\mathbf{2 2 . 5 \pm 0 . 8 4 ^ { \mathrm { e } }}$ & $0.73 \pm 0.03^{\mathrm{e}, \mathrm{f}}$ \\
\hline T13laeA & $20.6 \pm 0.20^{\mathrm{d}, \mathrm{e}}$ & $0.33 \pm 0.01^{\mathrm{b}}$ \\
\hline T12laeA & $18.8 \pm 0.06^{\mathrm{c}, \mathrm{d}}$ & $0.37 \pm 0.01^{\mathrm{b}}$ \\
\hline T1laeA & $18.4 \pm 0.74^{\mathrm{c}, \mathrm{d}}$ & $\mathbf{0 . 8 1} \pm 0.01^{\mathrm{f}}$ \\
\hline T15laeA & $18 \pm 0.45^{\mathrm{c}, \mathrm{d}}$ & $0.46 \pm 0.05^{\mathrm{b}, \mathrm{c}, \mathrm{d}}$ \\
\hline T16laeA & $17.9 \pm 0.48^{\mathrm{b}, \mathrm{c}, \mathrm{d}}$ & $0.56 \pm 0.05^{\mathrm{c}, \mathrm{d}}$ \\
\hline T2laeA & $17.6 \pm 0.86^{\mathrm{a}, \mathrm{b}, \mathrm{c}}$ & $0.15 \pm 0.03^{\mathrm{a}}$ \\
\hline T7laeA & $17.1 \pm 1.17^{\mathrm{a}, \mathrm{b}, \mathrm{c}}$ & $0.44 \pm 0.04^{\mathrm{b}, \mathrm{c}}$ \\
\hline T4laeA & $16.9 \pm 0.62^{\mathrm{a}, \mathrm{b}, \mathrm{c}}$ & $0.35 \pm 0.01^{\mathrm{b}}$ \\
\hline T14laeA & $14.9 \pm 0.67^{\mathrm{a}}$ & $0.59 \pm 0.05^{\mathrm{d}, \mathrm{e}}$ \\
\hline
\end{tabular}

Transformantes LaeA con promotor constitutivo. La segunda estrategia, basada en la construcción pUAMTPlaeAcons, expresando laeA constitutivamente, fue más laborioso para obtención de transformantes debido a la co-transformación realizada con el plásmido pULC43. Se obtuvieron sólo 12 transformantes resistentes a fleomicina de varias transformaciones realizadas, pero de las cuales, 10 transformantes mostraron mayor producción de lovastatina que la parental en FCA (>190 $\mu \mathrm{g}$ lov/mL vs $190 \mu \mathrm{g} l o v / m L$, respectivamente) y fueron seleccionadas para seguir su caracterización (Pérez et al., 2015). En este caso, como muestra la Tabla 5, todas las transformantes resultaron ser sobreproductoras de lovastatina en FS (con rango del 11 a $63 \%$ de incremento, respecto a la parental), destacando la T2laeAcons con un incremento del $63 \%$. Es interesante que sólo la T5laeAcons, resultó sobreproductora en FL con un incremento del $62 \%$. 
Tabla 5. Producción de lovastatina de transformantes con construcción pUAMTPlaeAcons en FS y FL (7d).

\begin{tabular}{|c|c|c|}
\hline $\begin{array}{c}\text { Transformantes } \\
\text { pUAMTPlaeAcons }\end{array}$ & $\begin{array}{c}\text { FS: Producción } \\
\text { Lovastatina } \\
\text { (mg/gss) }\end{array}$ & $\begin{array}{c}\text { FL: } \\
\text { Producción } \\
\text { Lovastatina } \\
\text { (mg/mL) }\end{array}$ \\
\hline Parental & $15.3 \pm 0.75^{\mathrm{a}}$ & $0.44 \pm 0.05^{\mathrm{b}}$ \\
\hline T2laeAcons & $\mathbf{2 4 . 8 \pm 0 . 6 1 ^ { \mathrm { f } }}$ & $0.30 \pm 0.03^{\mathrm{b}}$ \\
\hline T7laeAcons & $21.3 \pm 0.66^{\mathrm{e}}$ & $0.39 \pm 0.02^{\mathrm{b}}$ \\
\hline T9laeAcons & $20.7 \pm 0.30^{\mathrm{d}, \mathrm{e}}$ & $0.14 \pm 0.01^{\mathrm{a}}$ \\
\hline T4laeAcons & $20.3 \pm 1.44^{\mathrm{c}, \mathrm{d}, \mathrm{e}}$ & $0.15 \pm 0.02^{\mathrm{a}}$ \\
\hline T8laeAcons & $19.0 \pm 0.01^{\mathrm{b}, \mathrm{c}, \mathrm{d}, \mathrm{e}}$ & $0.36 \pm 0.02^{\mathrm{b}}$ \\
\hline T5laeAcons & $19.0 \pm 0.41^{\mathrm{b}, \mathrm{c}, \mathrm{d}, \mathrm{e}}$ & $\mathbf{0 . 7 2 \pm 0 . 0 4 ^ { \mathrm { c } }}$ \\
\hline T10laeAcons & $18.6 \pm 0.14^{\mathrm{b}, \mathrm{c}, \mathrm{d}}$ & $0.41 \pm 0.02^{\mathrm{b}}$ \\
\hline T1laeAcons & $17.9 \pm 1.28^{\mathrm{b}, \mathrm{c}}$ & $0.38 \pm 0.10^{\mathrm{b}}$ \\
\hline T6laeAcons & $17.8 \pm 0.17^{\mathrm{b}, \mathrm{c}}$ & $0.32 \pm 0.01^{\mathrm{b}}$ \\
\hline T3laeAcons & $16.9 \pm 0.62^{\mathrm{a}, \mathrm{b}}$ & $0.43 \pm 0.05^{\mathrm{b}}$ \\
\hline
\end{tabular}

\section{Integración de construcciones en transformantes seleccionadas}

Posteriormente se confirmó la integración de las construcciones correspondientes en las mejores transformantes para FS (T9laeA y T2laeAcons) y para FL (T1laeA y T5laeAcons), por Southern Blot y PCR.

Para confirmar la integración por PCR se diseñaron oligos que abarcaran parte del gen de interés (laeA) y parte del vector en donde se clonó, obteniendo fragmentos de ADN de tamaños distintos, tal como se muestra en la Tabla 6:

Tabla 6. Diseño de oligos para confirmar integración de construcciones en transformantes por PCR.

\begin{tabular}{|l|c|c|c|}
\hline \multicolumn{1}{|c|}{ Construcciones } & Transformantes & Ubicación de oligos forward y reverse & $\begin{array}{c}\text { Tamaño } \\
\text { esperado }\end{array}$ \\
\hline $\begin{array}{l}\text { pUAMTPlaeAcom } \\
\text { (vector pULC43 con } \\
\text { gen completo laeA) }\end{array}$ & T9 y T1laeA & Inserto de pUAMTPlaeA & $1,250 \mathrm{pb}$ \\
\hline $\begin{array}{l}\text { pUAMTPlaeAcons } \\
\text { (vector pAN52.1 con } \\
\text { gen cds laeA) }\end{array}$ & T2 y T5laeAcons & BamHI & Inserlo de pUAMTPlaeAcons \\
\end{tabular}

\footnotetext{
Tesis de Doctorado en Biotecnología
} 
Como se muestra en la Figura 18A, al amplificar el fragmento de ADN de 1,250 pb correspondiente a la construcción pUAMTPlaeA en las transformantes seleccionadas (T1laeA y T9laeA), se observó que sólo la T1laeA obtuvo el fragmento esperado, y en T9laeA no se logra distinguir la banda deseada, aunque se observaron otras bandas correspondientes a la construcción clonada. Mientras que en la Figura 18B, al amplificar el fragmento de ADN de $1,444 \mathrm{pb}$ correspondiente a la construcción pUAMTPlaeAcons en las transformantes T2laeAcons y T5laeAcons, se observó que ambas claramente amplifican el fragmento esperado.
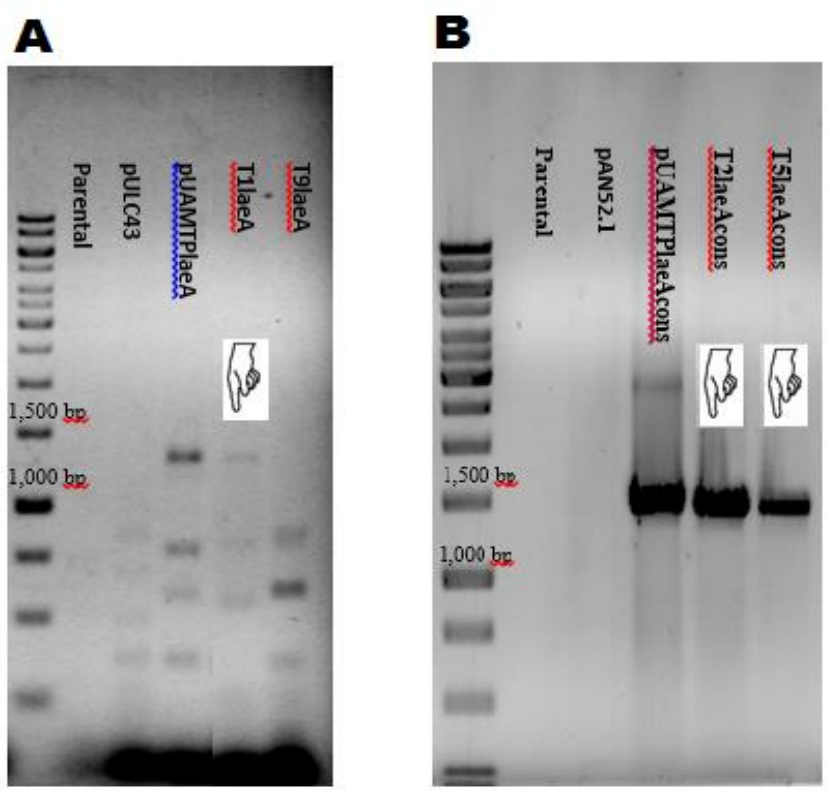

Fig. 18. Electroforesis para confirmar integración de construcciones en Transformantes seleccionadas: A) pUAMTPlaeA en T1 y T9laeA, B) pUAMTPlaeAcons en T2 y T5laeAcons.

Para confirmar lo obtenido por PCR y encontrar la integración de la construcción en la transformante T9laeA faltante se propuso realizar Southern Blot, que mediante una sonda radiactiva específica del gen lae $A$ se precisa mejor la integración de las construcciones clonadas. Primeramente, se diseñó y amplificó por PCR la sonda del gen laeA con un tamaño de 364 pb. Posteriormente, se realizó un análisis de enzimas de restricción, para que, tanto el gen endógeno (laeA nativo del genoma) como el exógeno (laeA integrado al genoma según construcción) tuvieran tamaño de fragmento de ADN diferentes al digerirlo, y poder identificarlos más fácilmente en la película revelada, obteniéndose los siguientes tamaños según Tabla 7: 
Tabla 7. Análisis de enzimas de restricción para confirmar integración de construcciones por Southern Blot.

\begin{tabular}{|c|c|c|c|c|}
\hline Construcciones & $\begin{array}{l}\text { Enzimas de } \\
\text { restricción }\end{array}$ & $\begin{array}{c}\text { Tamaños obtenidos en } \\
\text { construcciones (gen } \\
\text { exógeno) }\end{array}$ & $\begin{array}{c}\text { Tamaños obtenidos en } \\
\text { genoma (gen } \\
\text { endógeno) }\end{array}$ & $\begin{array}{c}\text { Mejores } \\
\text { Transformantes }\end{array}$ \\
\hline pUAMTPlaeA & $\begin{array}{l}\text { BamHI } \\
\text { EcoRV }\end{array}$ & $\begin{array}{l}\text { 2,600pb para laeA } \\
\text { 1,200pb Ppbc y ble } \\
\text { 3,700pb resto }\end{array}$ & 5,252pb para lae $A$ & $\begin{array}{l}\text { Parental; } \\
\text { T1 y T9laeA }\end{array}$ \\
\hline pUAMTPlaeAcons & $\begin{array}{l}\text { BamHI } \\
\text { Ncol }\end{array}$ & $\begin{array}{l}\text { 1,250pb para laeA } \\
5,721 \text { pb resto }\end{array}$ & 7,276pb para laeA & $\begin{array}{l}\text { Parental; } \\
\text { T2 y T5laeAcons }\end{array}$ \\
\hline
\end{tabular}

Para analizar la integración del gen exógeno laeA proveniente de la construcción, se observó claramente en la Figura 19A que la transformante T9laeA tiene integrado además del gen laeA endógeno (aprox. 5,200 pb), el gen laeA exógeno en varias copias (2,600 pb), además de otra banda en distinto tamaño aprox. de 3,400 pb. Mientras que la T1laeA mostro dos bandas (aprox. 3,400 y 4,200 pb), ambas más abajo de la banda control de la parental no encontrada (correspondiente al gen endógeno lae $A$ de 5,200 pb), al parecer por la tenuidad muy baja debido a la poca carga de ADN, además la integración del gen laeA exógeno resultó en una recombinación homóloga y heteróloga, lo que movió los tamaños de fragmentos deseados al cortarse con las enzimas de restricción utilizadas, sin, embargo, ya se había confirmado su integración por PCR (Figura 18A). Respecto a las transformantes TlaeAcons, se observó en la Figura 19B, que la transformante T2laeAcons además de tener el gen endógeno (aprox. $7,200 \mathrm{pb})$ tiene la integración del gen laeA exógeno (1,250pb), también confirmado por PCR. Mientras que la T5laeAcons, parece no tener integrado el gen laeA exógeno, pero se observaron muy tenues las bandas, por lo que suponemos poca carga de ADN digerido o era necesario más tiempo de exposición, sin embargo, en el PCR realizado anteriormente sí se amplificó claramente el fragmento del ADN esperado (Figura 18B). En forma general, podemos constatar que todas las transformantes seleccionadas tienen integrada la construcción correspondiente. 
A

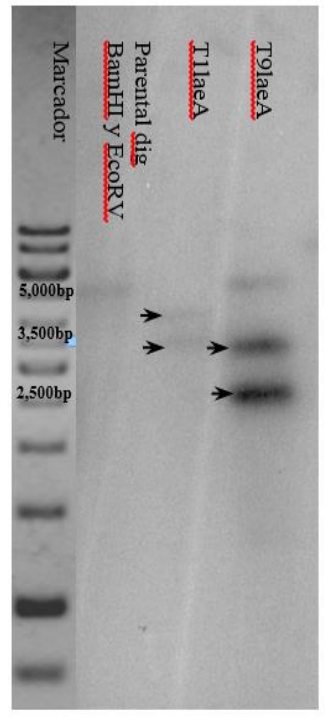

B

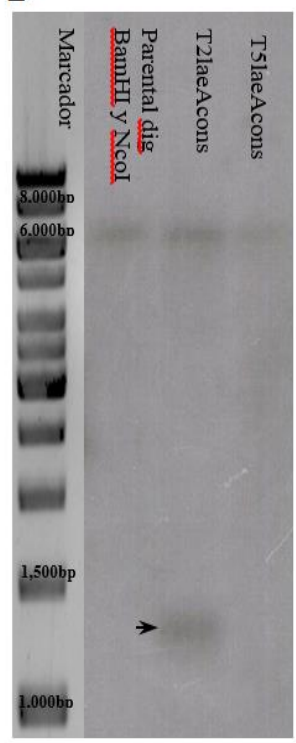

Fig. 19. Southern Blot con sonda laeA. A) Mejores transformantes con pUAMTPlaeA, B) Mejores transformantes con pUAMTPlaeAcons.

\section{Efecto de la SE::laeA sobre la producción de lovastatina en las mejores transformantes}

Para estudiar con más detalle el efecto de la SE::laeA sobre la producción de lovastatina se realizaron cinéticas de las mejores transformantes para cada sistema de cultivo. En FS, las transformantes T9laeA y T2laeAcons, y en FL, las transformantes T1laeA y T5laeAcons.

Las mejores transformantes para la FS y FL de ambas estrategias, tuvieron altos incrementos en la producción de lovastatina respecto a la parental. Como se muestra en la Figura 20, las mejores transformantes para FS, la T2laeAcons y la T9laeA, mostraron muy altos incrementos de producción de lovastatina, al día 9, de 104\% y 76\%, respectivamente, respecto a la parental. La T2laeAcons, que expresa constitutivamente laeA, desplazó el tiempo máximo de producción de lovastatina al día 9, debido a que mantiene altas tasas de producción desde la trofofase y sigue así en idiofase. Mientras que la T9laeA, que expresa laeA con su propio promotor, tuvo menor producción de lovastatina, en comparación a la T2laeAcons, desplazando el tiempo de producción (a alta tasa) sólo hasta el día 7, pero igual fue alta su producción respecto a la parental. Es importante notar que la parental dejó de producir a alta tasa el día 5. Es decir, que ambas transformantes modificaron la forma de sus cinéticas de 
producción, prolongando su tiempo de producción a altas tasas. Así, la T2laeAcons fue la mejor transformante en $\mathrm{FS}$, con una producción récord de $30.6 \mathrm{mg}$ lov/gss y le siguió la T9laeA con $26.4 \mathrm{mg}$ lov/gss, ambas al día 9.

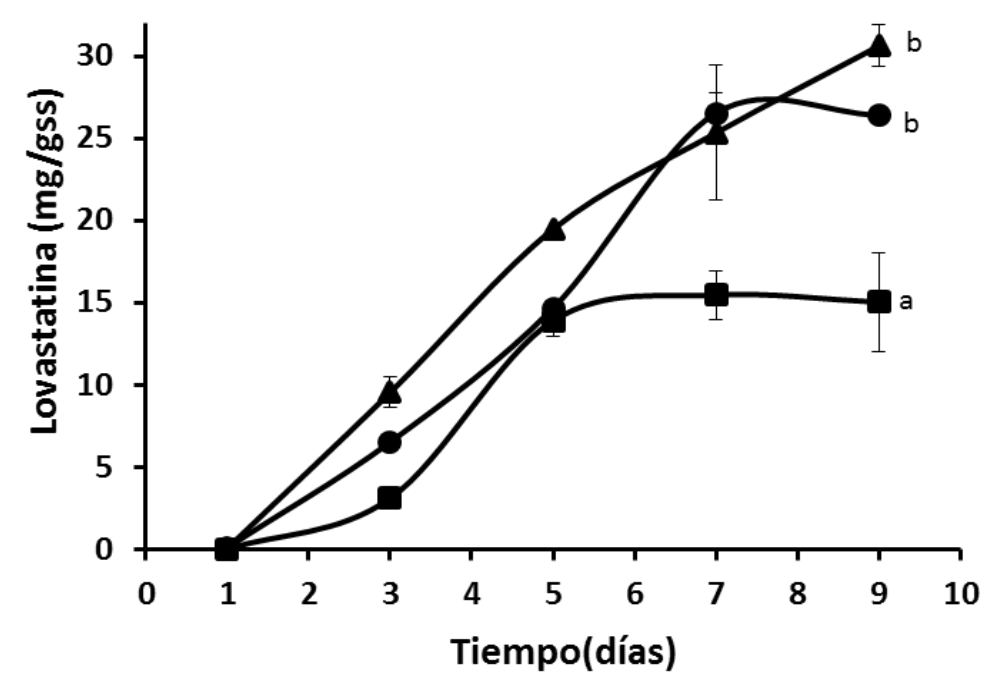

Fig. 20. Cinética de producción de lovastatina en FS de parental ( $\rightarrow-$ ) y mejores transformantes: T2laeAcons ( $\longrightarrow$ ) and T9laeA $(-\bullet)$ ).

Por otra parte, la T5laeAcons y la T1laeA, mejores transformantes para FL, también prolongaron el tiempo de producción del metabolito, mostrando un incremento en la producción de lovastatina (al día 9) de $112 \%$ y de $116.5 \%$, respectivamente (Figura 21). Respecto a la transformante que expresa laeA desde un promotor constitutivo (T5laeAcons), llama la atención la relativa constancia en tasa de producción durante toda la trofofase y la idiofase. Misma característica que se observó en la transformante con promotor constitutivo seleccionada para FS (T2laeAcons), descrita arriba. Así, ambas transformantes modificaron la forma de sus cinéticas, manteniendo alta producción hasta el día 9. Mientras que la T1laeA, con propio promotor, tuvo una alta tasa de producción al día 5 , siendo superior a la parental. Esto explica su incremento en la producción de estas transformantes, ya que la parental mantuvo una alta tasa de producción sólo hasta el día 3 en FL. Así, las 2 transformantes, fueron mejores productoras de lovastatina en $\mathrm{FL}$, con respecto a la parental, con producciones récord de lovastatina, al día 9 , de $0.87 \mathrm{mg}$ lov $/ \mathrm{mL}$ para T5laeAcons y $0.89 \mathrm{mg}$ lov $/ \mathrm{mL}$ para T1laeA. 


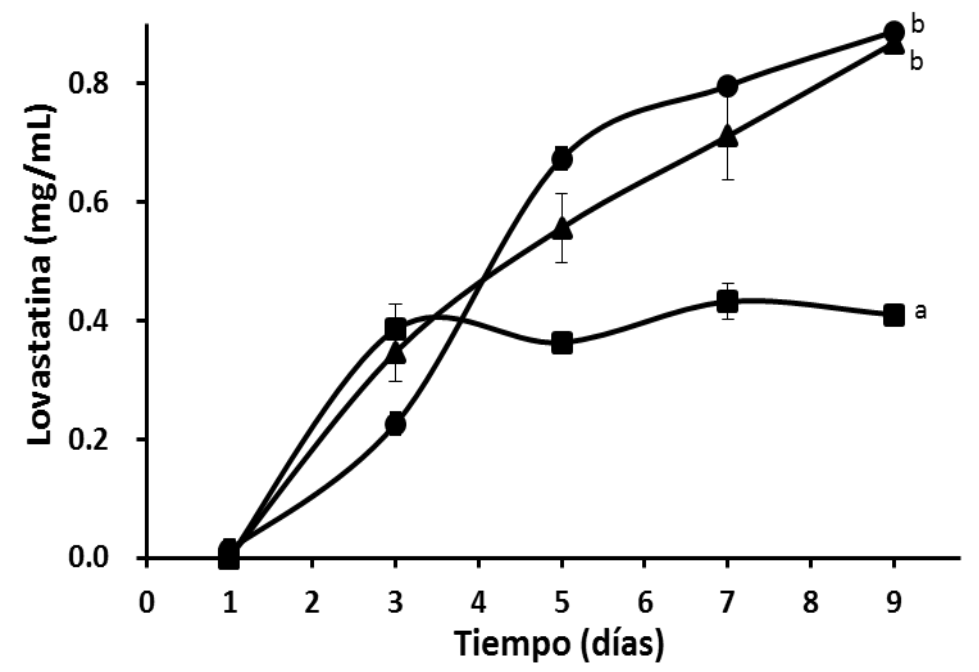

Fig. 21. Cinética de producción de lovastatina en FL de parental ( $\rightarrow$ ) y mejores transformantes: T5laeAcons ( $₫$ ) and T1laeA ( $\bullet-)$ ).

\section{Análisis de expresión de genes en parental y mejores transformantes}

\section{Extracción de RNA}

Se extrajo RNA de parental y mejores transformantes en FS (T2laeAcons y T9laeA) y FL (T5laeAcosn y T1laeA) a diferentes tiempos (18 h, 42 h, $3 \mathrm{~d}, 5 \mathrm{~d}$ y $7 \mathrm{~d}$ ) para posteriormente realizar qRT-PCR. Se observa en la Figura 22, buena integridad del RNA tanto de la parental como en las mejores transformantes, mostrándose en todos, los RNA ribosomales en dos bandas intermedias, el RNA de transferencia en bandas abajo y el RNA mensajero mostrado en toda la corrida, éste último fue de interés para el análisis de la expresión de los genes a estudiar.

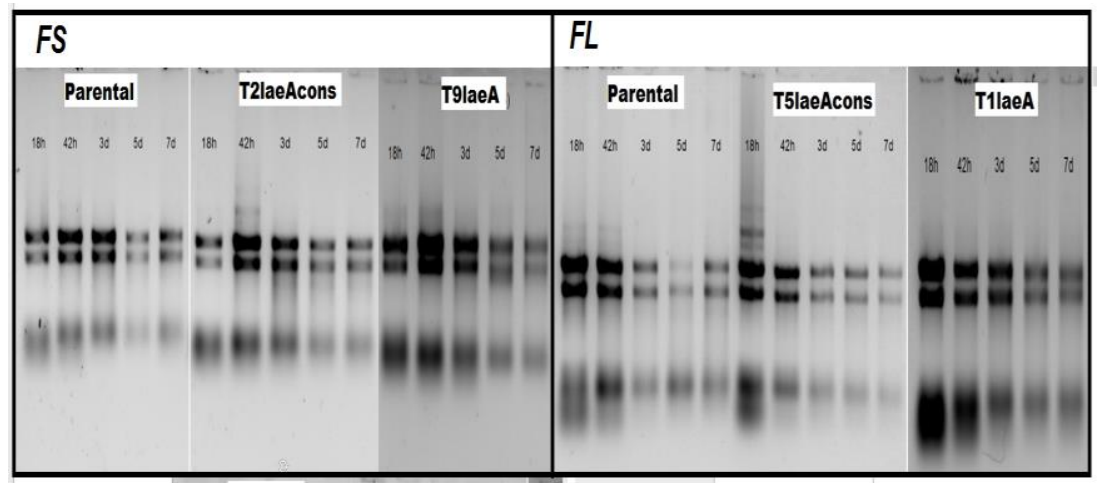

Fig. 22. Electroforesis de RNA de parental y mejores transformantes en FS y FL. 


\section{Niveles de expresión del gen laeA en mejores transformantes}

Para confirmar la SE::laeA en las mejores transformantes para cada sistema de cultivo, se realizó PCR en tiempo real (qRT-PCR) hasta el día 7. Como se muestra en la Figura 23, en FS, las mejores transformantes seleccionadas, T2laeAcons y T9laeA, llegaron a niveles de expresión del gen laeA superiores respecto a la cepa parental. Para T2laeAcons, la expresión de laeA subió fuertemente en todos los tiempos tanto en trofofase como idiofase, debido a su expresión constitutiva (más a las 18 h) con respecto a la parental. Mientras que T9laeA, también tuvo expresión muy elevada, pero inferior que la T2laeAcons, hasta incluso menor o similar que la parental en algunos tiempos, pero también mayor expresión muy significativa en otros, como a las 18 y $120 \mathrm{~h}$. La alta expresión de laeA en ambas transformantes se reflejó en la producción de lovastatina, iniciando su producción desde las $24 \mathrm{~h}$ y una producción a alta tasa desde las $72 \mathrm{~h}$ en T2laeAcons, siguiendo la T9laeA (Figura 20).

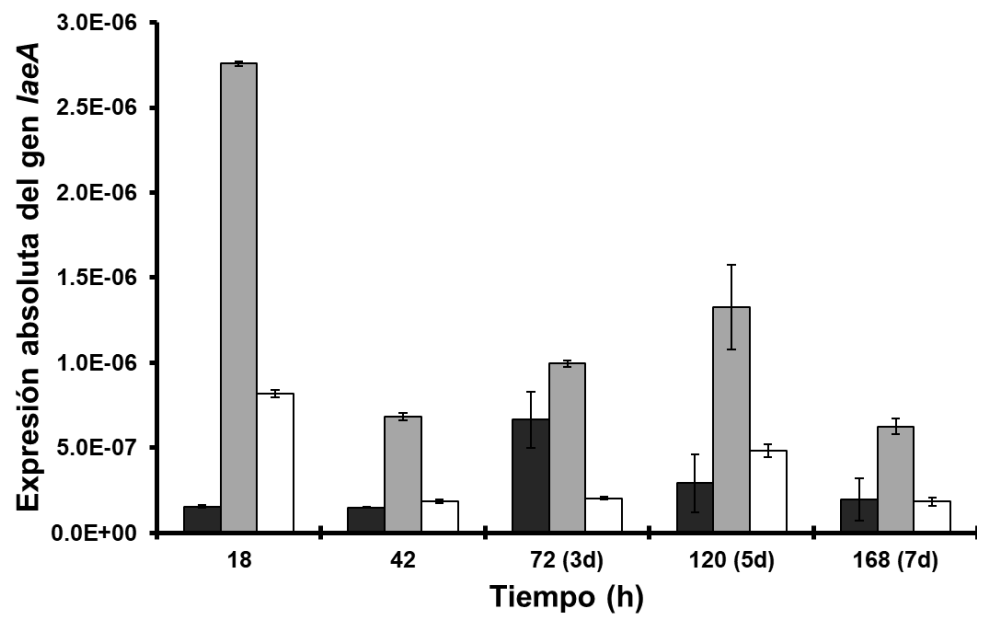

Fig. 23. Expresión absoluta del gen laeA en FS de parental ( $\boldsymbol{\square}$ ) y transformantes seleccionadas: T2laeAcons ( $\square$ ) y T9laeA ( $\square$ ).

Por otro lado, en FL, las mejores transformantes seleccionadas, la T5laeAcons y T1laeA, mostraron un mayor nivel de expresión de laeA de manera significativa respecto a la parental. Como se observa en la Figura 24, la expresión de laeA en la T5laeAcons, también debido a su expresión constitutiva, fue muy elevada en ambas fases de crecimiento, excepto por las 68 h $(7 \mathrm{~d}$ ). Mientras que en la T1laeA (con propio promotor laeA) también tuvo aumento significativo de la expresión de laeA en todos los tiempos, respecto a la parental, pero incluso fue mayor su expresión en algunos tiempos en trofofase (18 h), pero sobre todo en idiofase (7 
d) que la T5laeAcons, esto concuerda con lo observado en la producción de lovastatina de ambas transformantes desde las $72 \mathrm{~h}$ (Figura 21), llegando ambas a producciones de lovastatina a alta tasa. Por otro lado, parece ser que la expresión inicial de laeA en la trofofase (18 h) es la que nos da una idea clara de la producción posterior de lovastatina en la idiofase, y esto se observó tanto en parental como en transformantes seleccionadas.

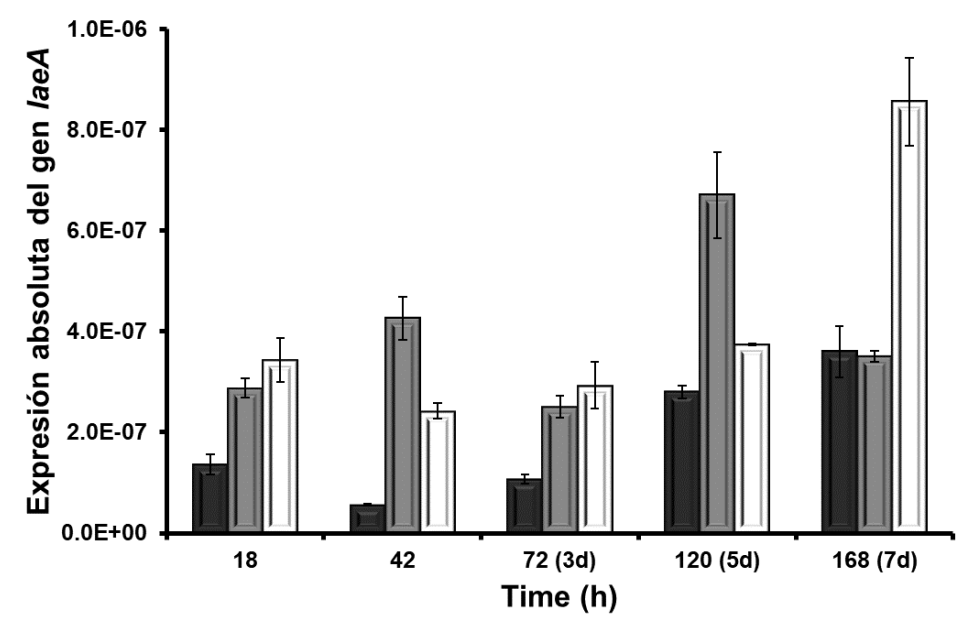

Fig. 24. Expresión absoluta del gen laeA en FL de parental ( $($ ) y transformantes seleccionadas: T5laeAcons (回) y T1laeA ( $\square$ ).

\section{Expresión de otros genes en mejores transformantes que SE::laeA}

Se analizó el perfil de expresión de algunos genes que se pensó se modificarían debido a la $\mathrm{SE}:$ :laeA. Como se mencionó anteriormente la expresión de fadA tuvo una clara relación con laeA en la parental. Tal pareciera que en las mejores transformantes para FS, tuvieron un claro aumento también en la expresión de fadA en algún tiempo analizado, más notable en la T2laeAcons en trofofase y ligeramente en la T9laeA en idiofase, mientras que en las mejores transformantes para FL, la SE::laeA tuvo un efecto opuesto sobre la expresión de fadA en trofofase en ambas transformantes, su expresión fue muy inferior respecto a la parental, no obstante, en idiofase si fue mayor su expresión tanto de la T5laeAcons como de la T1laeA (Figura 25A). Respecto a la expresión de lovE se observó que todas las transformantes seleccionadas en algún tiempo analizado tuvieron mayor expresión respecto a la parental, la T2laeAcons a las $18 \mathrm{~h}$, la T5laeAcons a las $72 \mathrm{~h}$, la T1laeA a las 42 y $72 \mathrm{~h}$, y la T9laeA a las $42 \mathrm{~h}$ (Figura 25C). Sin embargo, nosotros esperábamos que en todos los tiempos fuera mayor la expresión respecto a la parental, tal pareciera un comportamiento inverso de lovE respecto 
a la expresión de laeA. Forma similar pasa con la expresión de lovF, esperábamos que en todos los tiempos fuera mayor la expresión respecto a la parental y no fue así, se comportó de manera casi exacta a la expresión de lovE (Figura 25C y D), tal vez esta mayor expresión se vea reflejada en tiempos posteriores, pero no analizados. Lo que sí concuerda es la alta producción de lovastatina de las transformantes seleccionadas para FL (T5laeAcons y T1laeA) y la T9laeA (transformante seleccionada para FS con propio promotor gen laeA), con el incremento de expresión de lovE y lovF a las $72 \mathrm{~h}$. Respecto a la T2laeAcons, la mejor transformante FS, se observó comportamiento diferente, solo hubo incremento de expresión de lovE y lov $\mathrm{F}$ a las $18 \mathrm{~h}$ y después fue la expresión de ambos genes inferiores a la parental (Figura 25C y D). Esto causa curiosidad, acaso esta expresión inicial es suficiente para ser capaz dicha transformante de ser la campeona en la producción de lovastatina que todas las demás, por esta característica la hace especial al medio sólido.

Por otra parte se analizó la expresión de brlA, como se observó en la Figura 25E, la expresión aumento en T1laeA y T9laeA (transformantes con propio promotor gen laeA) en la idiofase (72 h), mientras que en transformantes con promotor constitutivo, sólo la T5laeAcons (mejor transformantes para $\mathrm{FL}$ ) aumento un poco a las 42 y $72 \mathrm{~h}$ respecto a la parental, mientras que en la T2laeAcons (mejor transformante FS) disminuyo la expresión de brlA significativamente a las $72 \mathrm{~h}$, siendo menor que la parental.

Respecto a otro factor transcripcional, relacionado con la respuesta al estrés, está el gen $m s n A$, éste tuvo un comportamiento distinto en las diferentes transformantes. Para la T2laeAcons disminuyó su expresión en todos los tiempos analizados, en la T5laeAcons fue casi igual, en la T9laeA fue prácticamente alta la expresión en todos los tiempos, y en la T1laeA aumentó la expresión, pero sólo a las 72 h, respecto a la parental (Figura 25F).

En general, hubo importantes cambios en la expresión de los distintos genes, se encontró una estrecha relación del gen laeA con el clúster de genes biosintético de lovastatina, con la esporulación y con la respuesta al estrés, todos ellos interconectados en la vía de señalización AMPc-PKA. 


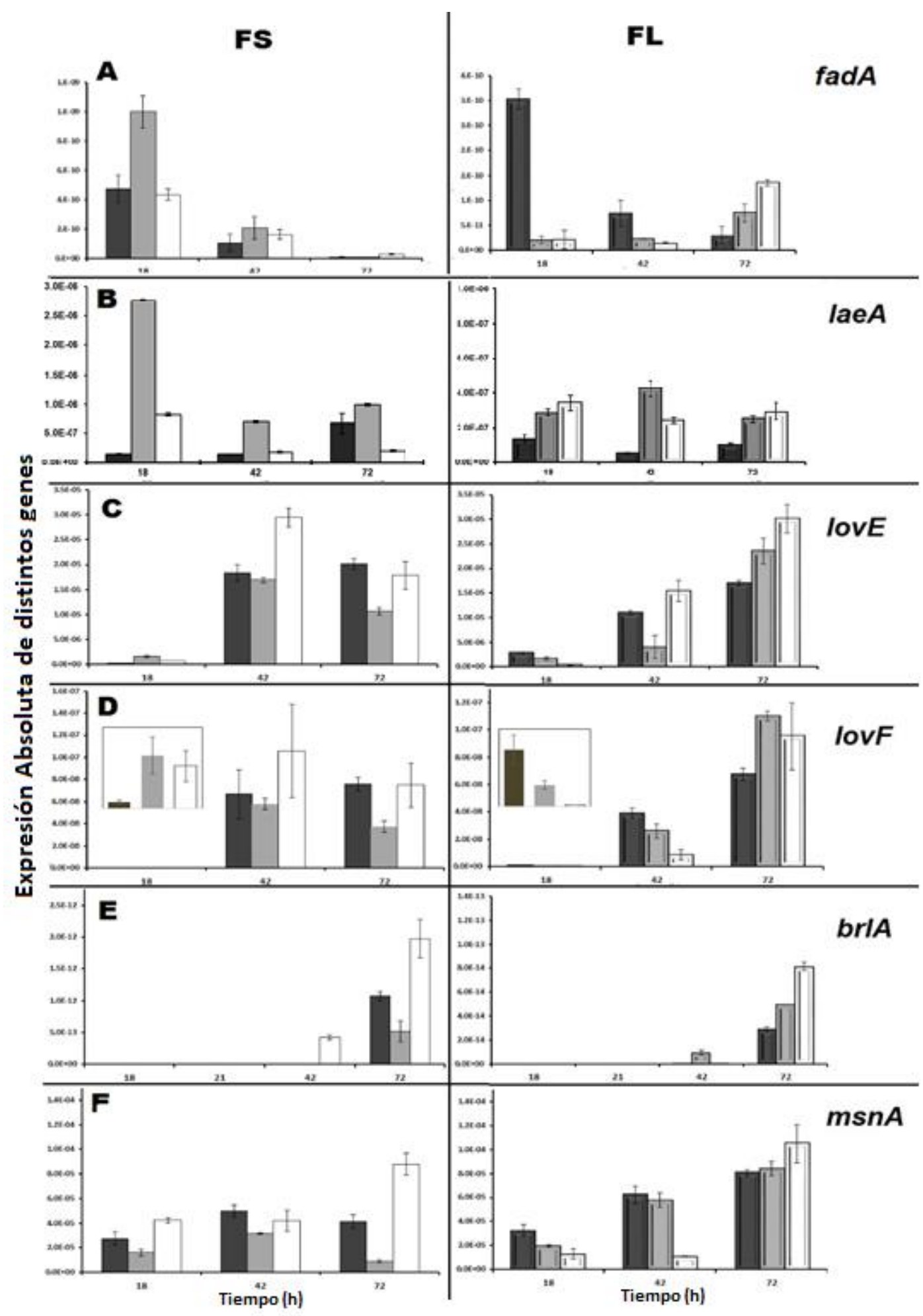

Fig. 25. Expresión absoluta de genes: fadA (A), laeA (B), lovE (C), lovF (D), brlA (E) y $m s n A$ (F). En FS de parental $(\square$ ) y mejores transformantes para FS: T2laeAcons ( $\square$ ) y T9laeA ( $\square$ ). En FL de parental ( $($ ) y mejores transformantes para FL: T5laeAcons (回) y T1laeA (司). 


\section{Efecto de la SE::laeA sobre la esporulación y otros parámetros fisiológicos relacionados con la vía AMPc-PKA}

Se estudiaron varios parámetros en varias transformantes de cada estrategia (promotor propio del gen laeA y promotor constitutivo), obtenidas como buenas productoras de lovastatina.

\section{Esporulación}

Para observar el efecto de la SE::laeA sobre esporulación, se observó en la Figura 26, que en general, todas las transformantes que SE::laeA con su propio promotor, presentaron un incremento en la esporulación al día 5, resultando un incremento promedio (del grupo) del 240\%. Las mejores transformantes de esta estrategia, T1laeA y T9laeA, tuvieron un incremento de esporulación del 75 y 135\% respectivamente, respecto a la parental, y esto se vio reflejado con la alta expresión del factor transcripcional de esporulación $b r l A$, de ambas transformantes a las $72 \mathrm{~h}$ (Figura 25D).

Respecto a las transformantes que SE::laeA con promotor constitutivo, sólo 4 de 7 tuvieron un incremento en la esporulación respecto a la parental, presentando un incremento promedio (del grupo) de 65\%. Las mejores transformantes, T2laeAcons y T5laeAcons, exhibieron incrementos de 9 y 24\% respectivamente, también reflejándose en la poca acumulación del transcrito brlA en la T2laeAcons y más alta expresión de este gen en la T5laeAcons a las 72 $\mathrm{h}$, respecto a la parental (Figura 25D).

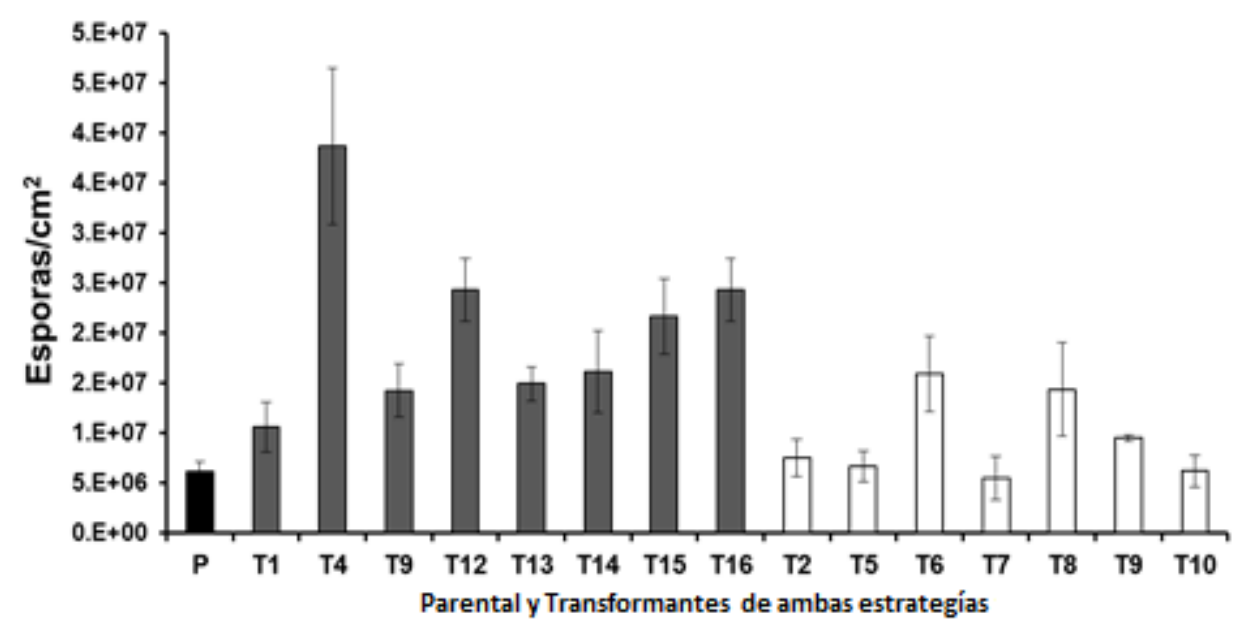

Fig. 26. Esporulación de parental ( $\square$ ), transformantes pUAMTPlaeA ( $\square$ ) y pUAMTPlaeAcons ( $\square$ ). 


\section{Crecimiento radial}

El efecto de la SE::laeA en las transformantes sobre el crecimiento radial se observó notablemente, tal como se muestra en la Tabla 8. Casi todas tuvieron un incremento en su crecimiento radial. No se pudo ver una relación clara entre crecimiento radial y el incremento en la producción de lovastatina tanto en FS como FL de cada transformante.

Sin embargo, las mejores transformantes para FS (T2laeAcons y T9laeA) y las mejores transformantes para FL (T5laeAcons y T1laeA) sí tuvieron un crecimiento radial superior a la parental, pero no tan alto como se mostró en otras transformantes con incrementos en su producción no tan elevados.

Tabla 8. Crecimiento radial e incremento en la producción de lovastatina en transformantes pUAMTPlaeAcons y pUAMTPlaeA en FS y FL.

\begin{tabular}{|c|c|c|c|c|}
\hline \multirow[t]{2}{*}{ Estrategias } & Transformantes & Diámetro (cm/día) & $\begin{array}{c}\text { Incremento } \\
\text { FS (\%)* }\end{array}$ & $\begin{array}{c}\text { Incremento } \\
\text { FL (\%) }\end{array}$ \\
\hline & Parental & $0.614 \pm 0.01^{a, b}$ & & \\
\hline \multirow{8}{*}{$\begin{array}{c}\text { Transformantes } \\
\text { SE::lae } A \text { con propio } \\
\text { promotor }\end{array}$} & T9laeA & $0.629 \pm 0.02^{h}$ & 47 & 65 \\
\hline & T13laeA & $0.541 \pm 0.04^{\mathrm{e}, \mathrm{f}, \mathrm{g}, \mathrm{h}}$ & 35 & -26 \\
\hline & T12laeA & $0.786 \pm 0.02^{\mathrm{f}, \mathrm{g}, \mathrm{h}}$ & 23 & -17 \\
\hline & T1laeA & $0.736 \pm 0.05^{b, c, d}$ & 20 & 82 \\
\hline & T15laeA & $0.727 \pm 0.02^{\mathrm{d}, \mathrm{e}, \mathrm{f}, \mathrm{g}}$ & 18 & 5 \\
\hline & T16laeA & $0.652 \pm 0.003^{b, c, d, e}$ & 18 & 26 \\
\hline & T4laeA & $0.704 \pm 0.01^{a}$ & 11 & -20 \\
\hline & T14laeA & $0.656 \pm 0.002^{b, c, d, e}$ & -2 & 34 \\
\hline \multirow{7}{*}{$\begin{array}{l}\text { Transformantes } \\
\text { SE::laeA con } \\
\text { promotor } \\
\text { constitutivo }\end{array}$} & T2laeAcons & $0.730 \pm 0.002^{\mathrm{e}, \mathrm{f}, \mathrm{g}, \mathrm{h}}$ & 63 & -31 \\
\hline & T7laeAcons & $0.782 \pm 0.005^{d, e, f}$ & 40 & -12 \\
\hline & T9laeAcons & $0.689 \pm 0.005^{e, f, g}$ & 36 & -68 \\
\hline & T8laeAcons & $0.696 \pm 0.005^{\mathrm{c}, \mathrm{d}, \mathrm{e}, \mathrm{f}}$ & 25 & -18 \\
\hline & T5laeAcons & $0.673 \pm 0.002^{\mathrm{g}, \mathrm{h}}$ & 24 & 62 \\
\hline & T10laeAcons & $0.707 \pm 0.01^{a, b}$ & 22 & -8 \\
\hline & T6laeAcons & $0.589 \pm 0.005^{\mathrm{c}, \mathrm{d}, \mathrm{e}, \mathrm{f}}$ & 17 & -28 \\
\hline
\end{tabular}

* Transformantes mostrados en orden descendiente al incremento en la producción de lovastatina en FS. 


\section{Estrés oxidativo}

Se evaluó la resistencia al estrés oxidativo de las transformantes obtenidas con cepa parental, con la finalidad de encontrar una posible relación de LaeA con el estrés oxidativo. Las esporas de las transformantes y parental se inocularon en placas con medio PDA a una concentración de $140 \mathrm{mM}$ de $\mathrm{H}_{2} \mathrm{O}_{2}$, y se midió el crecimiento (diámetro) de las colonias al día 4.

Como se puede observar en la Tabla 9, la mayoría de las transformantes que SE::laeA con propio promotor fueron sensibles al estrés oxidativo. Sin embargo, un $37.5 \%$ de las transformantes mostraron un fenotipo de resistencia. Es interesante notar que, dentro de las resistentes a $\mathrm{H}_{2} \mathrm{O}_{2}$, se encontraron las mejores transformantes sobreproductoras de esta estrategia (T9 y T1laeA). Además, éstas fueron de las pocas que sobreprodujeron lovastatina en ambos sistemas de cultivo. Por otra parte, las transformantes que SE::laeA desde un promotor constitutivo, todas mostraron un fenotipo de sensibilidad al estrés oxidativo y las menos sensibles fueron las mejores transformantes de esta estrategia (T2 y T5laeAcons).

Se relacionó la expresión del gen $m n s A$, por ser un factor transcripcional de respuesta al estrés, (Figura 25E), observándose mayor acumulación del transcrito en la T9 y T1laeA a las 72h. En contraste, T2 y T5laeAcons, mostraron menos expresión de $m s n A$, que la parental. Coincidiendo esto con su sensibilidad al estrés oxidativo.

Tabla 9. Sensibilidad al estrés oxidativo. Efecto del $\mathrm{H}_{2} \mathrm{O}_{2}(140 \mathrm{mM})$ en la tasa de crecimiento radial de transformantes $\mathrm{SE}:: / a e A$, con respecto a la parental, en placas de PDA.

\begin{tabular}{|c|c|c|}
\hline \multirow{4}{*}{ Estrategias } & Transformantes & $\begin{array}{c}\text { Incremento } \\
\text { en } \\
\text { crecimiento } \\
\text { de colonias } \\
(\%)\end{array}$ \\
\hline \multirow{4}{*}{$\begin{array}{c}\text { Transformantes } \\
\text { con propio } \\
\text { promotor laeA }\end{array}$} & T1laeA & $\mathbf{1 4 4}$ \\
\cline { 2 - 3 } & T9laeA & $\mathbf{2 7}$ \\
\cline { 2 - 3 } & T16laeA & 15 \\
\cline { 2 - 3 } & T12laeA & -49 \\
\cline { 2 - 3 } & T15laeA & -65 \\
\cline { 2 - 3 } & T14laeA & -76 \\
\cline { 2 - 3 } & T4laeA & -95 \\
\hline \multirow{4}{*}{$\begin{array}{c}\text { Transformantes } \\
\text { con promotor } \\
\text { constitutivo }\end{array}$} & T13laeA & -97 \\
\cline { 2 - 3 } & T2laeAcons & $-\mathbf{- 4 4}$ \\
\cline { 2 - 3 } & T5laeAcons & $\mathbf{- 5 6}$ \\
\cline { 2 - 3 } & T6laeAcons & -89 \\
\cline { 2 - 3 } & T7laeAcons & -89 \\
\cline { 2 - 3 } & T8laeAcons & -78 \\
\cline { 2 - 3 } & T9laeAcons & -100 \\
\cline { 2 - 3 } & T10laeAcons & -100 \\
\hline
\end{tabular}




\section{Estrés osmótico}

También se evaluó la posible relación de LaeA con el estrés osmótico. Las esporas de las transformantes y parental se inocularon en placas con medio PDA a una concentración de 2.9 $\mathrm{M} \mathrm{NaCl}$, y se observó crecimiento de colonias al día 3 .

Como se observó en la Figura 27, casi todas las transformantes que SE::/aeA con su propio promotor mostraron poca sensibilidad al estrés osmótico, incluyendo las mejores transformantes (T1 y T9laeA). Sin embargo, hubo 2 transformantes con resistencia (T4 y T13 laeA) y una sensible (T12laeA), las cuales exhibieron un incremento de producción moderado en FS y decremento moderado en FL.

Mientras que, en las transformantes que SE::/aeA con promotor constitutivo (Figura 28) se observó que en la mayoría no hubo cambio en la sensibilidad al estrés osmótico, es decir, tuvieron crecimiento similar a la cepa parental, o ligeramente más resistentes (como la T5laeAcons: mejor transformante para FL). Sólo T10laeAcons y T2laeAcons (mejor transformante para FS) fueron sensibles.

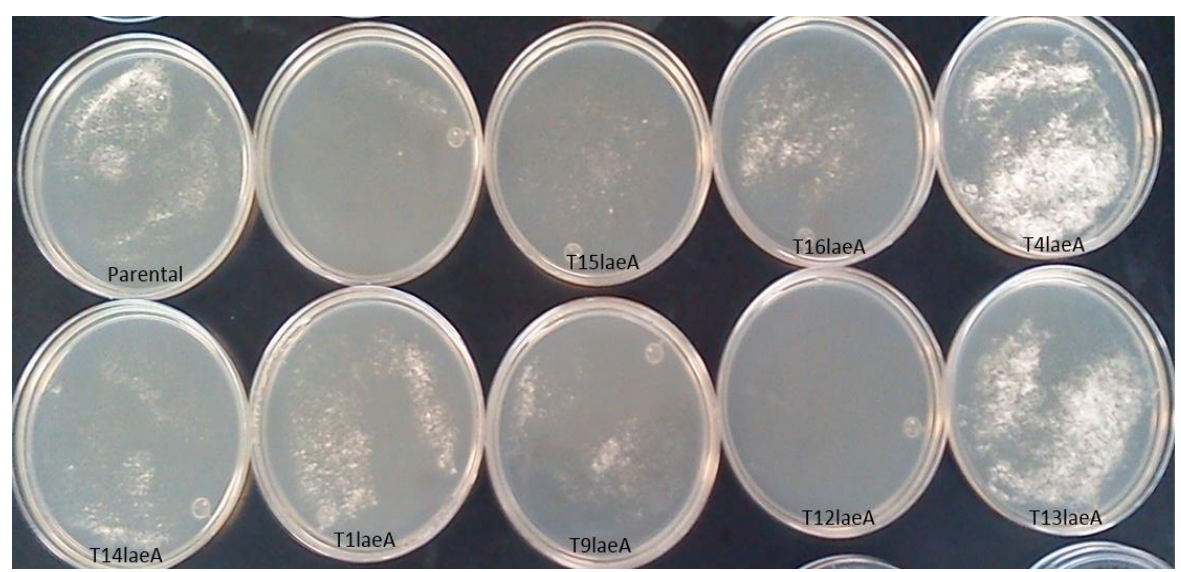

Fig. 27. Sensibilidad a estrés osmótico. Crecimiento de parental y transformantes que SE::laeA con propio promotor, en placas PDA con $2.9 \mathrm{M} \mathrm{NaCl}$. 


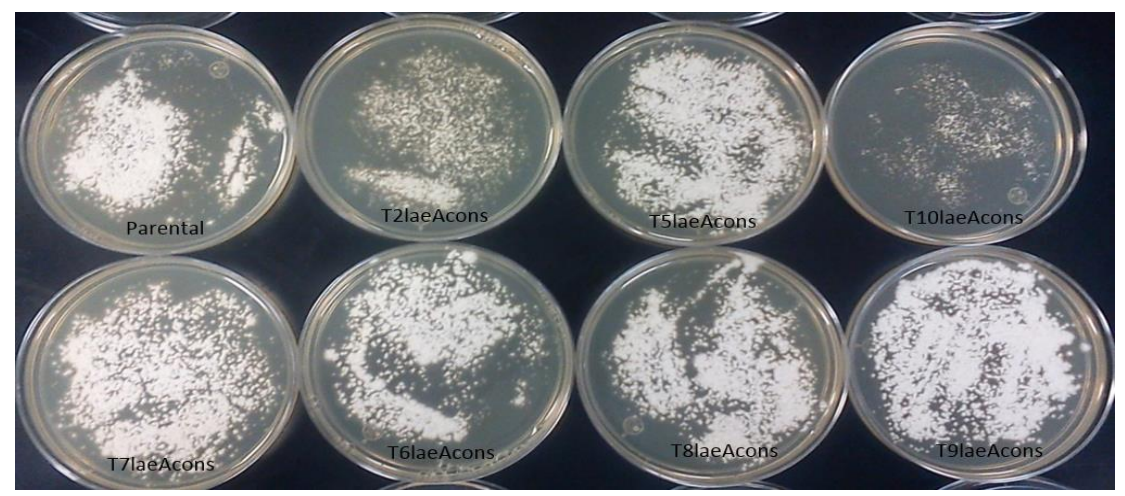

Fig. 28. Sensibilidad a estrés osmótico. Crecimiento de parental y transformantes que SE::laeA con promotor constitutivo, en placas PDA con $2.9 \mathrm{M} \mathrm{NaCl}$.

\section{Morfología colonial}

Finalmente se evaluó el efecto de la SE::laeA sobre la morfología colonial. Se encontró que todas las transformantes mostraban algún cambio en su morfología, como falta de pigmentación, bordes lobulados o consistencia esponjosa (Figura 29). Específicamente la T2laeAcons mostró una consistencia esponjosa y poca pigmentación, la T5laeAcons, bordes lobulados y finalmente la T1laeA y T9laeA, poca pigmentación y aparición de sectores.

Concluyendo que LaeA si influye de alguna manera en la morfología colonial.

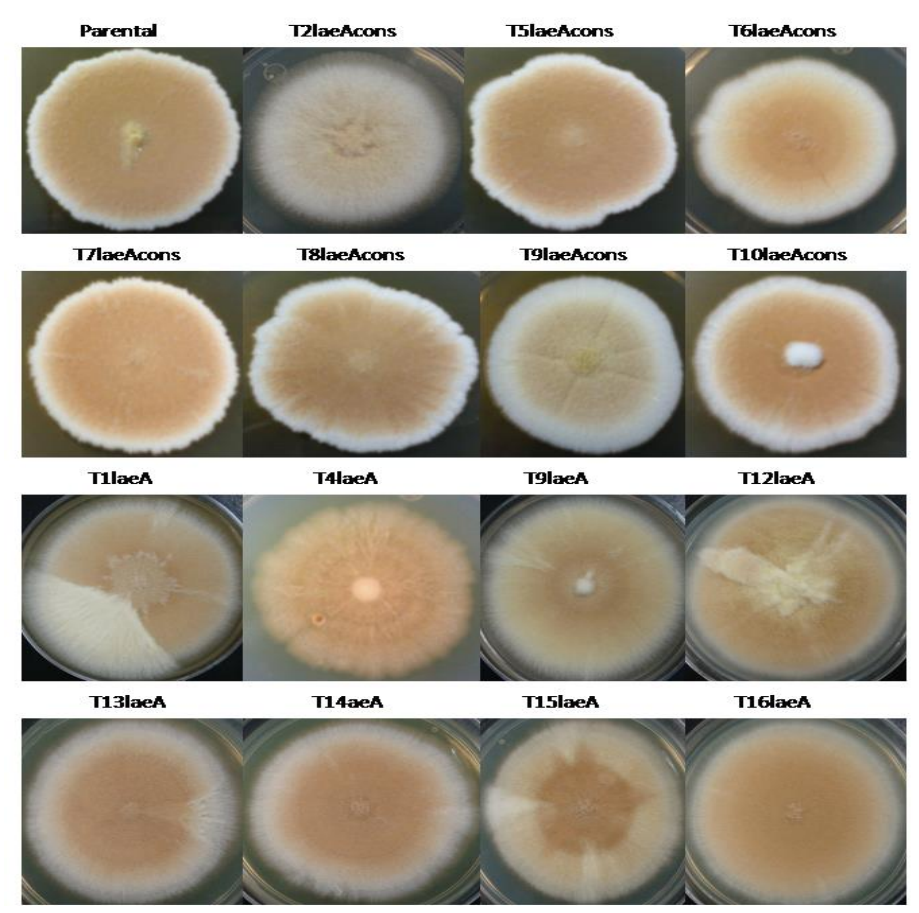

Fig. 29. Morfología de transformantes con propio promotor laeA y constitutivo. 


\section{DISCUSIÓN}

Como se entiende actualmente, la cascada de señalización ligada a la esporulación y el metabolismo secundario en Aspergillus spp. está centrada sobre la vía de transducción de señales proteína $\mathrm{G} / \mathrm{AMP} / \mathrm{PKA}$ la que regula una variedad de procesos del desarrollo en hongos. Proteínas $G$ heterotriméricas específicas acopladas a receptores transmembranales, donde FadA es parte de una proteína $G$ heterotrimérica $[\mathrm{FadA}(\mathrm{G} \alpha):: \operatorname{SfaD}(\mathrm{G} \beta):: \mathrm{GpgA}(\mathrm{G} \gamma)]$, controlan la síntesis de AMPc por el adenilato ciclasa y la degradación por fosfodiesterasa (Seo et al., 2005; Yu, 2006). Se sabe que el AMPc activa la proteína quinasa A (PKA). PKA, otro componente clave de señalización, transmite una señal a numerosos objetivos en el citoplasma y núcleo a través de una cascada de fosforilación-desfosforilación. Aunque se conocen las características generales de señalización AMPc-PKA en los hongos filamentosos, los mecanismos detallados relacionados con el control de conidiación y metabolismo secundario no son ampliamente conocidos en hongos modelo, y mucho menos en el hongo filamentoso Aspergillus terreus, ni su relación con la biosíntesis de lovastatina. Por lo anterior, en esta tesis se estudiaron varios puntos clave de esta vía de señalización en fase de crecimiento (trofofase), y su relación con la producción de lovastatina, resistencia a estrés y esporulación (idiofase). Los resultados fueron comparados con lo que se ha encontrado en investigaciones con otros hongos.

Se inició este estudio con el análisis de parámetros fisiológicos en fermentación sólida (FS) y fermentación líquida ( $\mathrm{FL}$ ) en $A$. terreus. La producción del metabolito secundario de este hongo filamentoso (lovastatina), se llevó a cabo en un medio complejo de tipo industrial ya optimizado por Szakács (1998). Para FS, se empleó un novedoso sistema de cultivo sólido con poliuretano como soporte inerte artificial, impregnado con dicho medio líquido, optimizado por Baños et al. (2009; Patente UAM, MX 256998), utilizando la misma cepa parental de A. terreus TUB-514. 


\section{Producción de lovastatina en FS y FL en medio complejo}

En la presente tesis se corroboró que la producción del metabolito secundario (lovastatina) fue mucho mayor en FS respecto a la FL ( $15.45 \mathrm{mg} / \mathrm{gss}$ (g sustrato seco) vs $0.43 \mathrm{mg} / \mathrm{mL}$ ). Por otro lado, la producción específica al día 5, fue 9 veces mayor en la FS respecto a la FL. Los resultados en general fueron semejantes a estudios anteriores y, tal como lo refirió BarriosGonzález (2012), la producción superior de lovastatina en FS es parte de la llamada fisiología del medio sólido. Es decir, que el hongo en medio sólido tiene un comportamiento distinto al mostrado en medio líquido. Dicha fisiología mostrada por hongos y otros microorganismos en FS no se entiende completamente, pero los recientes avances empiezan a obtener un panorama interesante y amplio. Se ha encontrado que, muchas ventajas de la FS son una consecuencia de la diferente fisiología mostrada por microorganismos en medio sólido, en relación a la FL. Citando algunas, son los altos rendimientos en la producción de metabolitos secundarios o enzimas, y en periodos más cortos en FS (Barrios-González et al., 1988; AcunaArguelles et al., 1995; Díaz-Gódinez et al., 2001; Krishna, 2005; Elinbaum et al., 2002; Maldonado y Strasser de Saad, 1998; Barrios-González y Mejía, 2007; Balakrishnan y Pandey, 1996; Robinson et al., 2001); que enzimas de FS muestran diferentes características como peso molecular, parámetros cinéticos y condiciones óptimas (Acuna-Arguelles et al., 1995; Hölker y Lenz, 2005); que muchas enzimas que son extracelulares en FS son intracelulares en FL (Lehka y Lonsane, 1994) y que ciertas enzimas o metabolitos secundarios son producidos solamente en FS aun cuando el organismo exhibe buen crecimiento en FL (Bigelis et al., 2006; Segeth et al., 2003). Además, se encontró que, buenas cepas productoras en FL, generalmente no son buenas productoras o no se desarrollan bien en FS, y viceversa (BarriosGonzález et al., 1993; Barrios-González y Mejía, 2009; Shankaranand et al., 1992). Todo ello, nos incentiva a de desarrollar cepas especiales para FS, ya que conllevan muchas ventajas como se ha descrito (Barrios-González et al., 1993; Barrios-González y Mejía, 2007 y 2009).

Referente a las razones moleculares y fisiológicas subyacentes al diferente comportamiento de los microorganismos en medio sólido todavía son poco comprendidas. Hasta ahora se ha encontrado que hay una gran cantidad de genes que se expresan de manera diferencial, dependiendo si se encuentra en FS o FL. Barrios-González J., (2012) encontró que la mayor producción de metabolitos secundarios se relaciona con una mayor transcripción de genes biosintéticos, mientras que estudios sobre la producción de enzimas en FS han identificado 
(genes) enzimas específicas para FS, lo cual ha contribuido a proporcionar una visión más profunda en su regulación (Oda et al., 2006).

Estos hechos sugieren que, el hongo recibe señales que indican que está en uno u otro sistema de cultivo y que esto hace generar una expresión diferencial de genes que dan como resultado una fisiología diferente (Hisada et al., 2005; Barrios-González et al., 2008), tal como se encontró en el análisis de genes involucrados en la vía AMPc-PKA de esta tesis.

Respecto a las señales percibidas por la vía AMPc-PKA, ya se han identificado estímulos (señales) que inducen la fisiología del medio sólido, por ejemplo, la actividad de agua en $A$. oryzae que juegan un papel importante en este contexto; el contacto directo con el aire y el estímulo del soporte (que induce exploración de colonización, adhesión, etc.) y en menor grado para el metabolismo secundario, la baja actividad de agua (Ávila et al., 2017). Esta vía percibe señales ambientales, principalmente nutricionales, pero también otras que podrían incluir estímulos que inducen la fisiología de medio sólido. Estas señales son captadas por receptores en la membrana y transducidos por vías de señalización. En esta tesis, se estudió el papel que puede estar jugando la vía AMPc-PKA en FS y FL.

Gracias al trabajo de varios grupos de investigación, sobresaliendo el de Nancy Keller y colaboradores, ha habido grandes avances en la comprensión del papel de esta vía en el crecimiento, en la producción de metabolitos secundarios, resistencia a estrés y desarrollo asexual y sexual. Es importante tener en cuenta que, esta vía de señalización está interconectada con otras cascadas de señalización creando una red de señalización compleja, pero minuciosamente regulada en Aspergillus sp. (Pusztahelyi y Pócsi, 2013).

En esta tesis, se encamino a hacer un análisis de distintos genes y componentes implicados, y que son clave en la vía de señalización AMPc-PKA, para tratar de ampliar el conocimiento de esta vía en ambos sistemas de cultivo y comprender mejor la fisiología del medio sólido.

Para complementar estos estudios, se sobreexpresó el gen laeA (SE::laeA), cuya proteína es un componente clave de la vía AMPc-PKA y que funciona como un regulador global y primordial en la producción de múltiples metabolitos secundarios en Aspergillus spp. Por otra parte, se realizó la caracterización de las mejores transformantes para ver su papel en la fisiología del medio sólido. Y se evaluó esto como un posible método de mejoramiento genético para la sobreproducción de lovastatina. 


\section{Estudio de los componentes principales de la vía AMPc-PKA: perfiles de expresión}

Se inició con el estudio de la expresión del gen fadA (subunidad a de la proteína G heterotrimérica) para saber si esta expresión es proporcional a su participación en la señalización con PKA y si FadA está relacionada con la producción del metabolito secundario (lovastatina) y conidiación, como se ha encontrado en estudios con otros hongos.

Se observó que el patrón de expresión fadA tuvo comportamientos distintos en ambos sistemas de cultivo, específicamente en la trofofase: la expresión de fadA en FS fue generalmente más baja que la encontrada en $\mathrm{FL}$, la cual se observó intensa prácticamente en toda la trofofase. En idiofase, la expresión fue baja en ambos sistemas de cultivo. Es decir, que la acumulación de transcritos de $\operatorname{fad} A$, en la fase de producción, fue similar en $\mathrm{FS}$ y $\mathrm{FL}$, siendo su expresión regulada negativamente.

El patrón de transcripción de fadA, fue coherente con el modelo de funcionamiento de la vía AMPc-PKA propuesto por el grupo de N. Keller. Es decir, los resultados de esta tesis, coinciden con los estudios realizados por Shimizu y Keller (2001), y Keller et al. (2005), donde demostraron que FadA $(G \alpha)$ estimula la actividad proteína quinasa $A$ (PKA) dependiente de AMPc, resultando, al menos en parte, en inhibición de conidiación y biosíntesis de ST en $A$. nidulans y AF en $A$. parasiticus, referido en esta tesis, en la inhibición de la conidiación y de la biosíntesis de lovastatina en la trofofase en $A$. terreus (específicamente a las $21 \mathrm{~h}$ en FS y 16 -18 h en FL, siendo alta la expresión de $\operatorname{fad} A$ ) cuando el hongo está en fase de crecimiento. Apoyando esto, la regulación negativa de la biosíntesis de AF y la formación de conidios, por la vía de señalización FadA/PKA fue observada en $A$. parasiticus (Roze et al., 2004). Por lo que, Yu et al. (1996) y Hicks et al. (1997), propusieron que la regulación del crecimiento, conidiación y biosíntesis de ST en $A$. nidulans, está bajo el control de una proteína $\mathrm{G}$ heterotrimérica, proponiendo que FadA regula positivamente al adenilato ciclasa, la cual incrementa el nivel de AMPc, lo que resulta en activación de PKA. Esto ocasiona, al menos en parte, regulación negativa de AfIR (factor transcripcional específico del clúster biosintético en la síntesis ST) y factores transcripcionales implicados en conidiación, siendo ambos controlados por un regulador global llamado LaeA. Sin embargo, cuando el estímulo de bajos niveles de nutrientes es captado por las proteínas $G$, no se disocian las subunidades $\alpha$, de la $\beta$ y $\mathrm{v}$, no sube la concentración de AMPc y no se activa PKA. Así posteriormente, se activa 
laeA, y se da el metabolismo secundario, la esporulación y la resistencia a estrés. Pero existe otra evidencia, que sugiere que FadA puede estar siendo regulada negativamente por FlbA, específicamente en la idiofase analizando nuestros resultados. Esta regulación se da mediante la estimulación de la hidrólisis de GTP, así, FadA-GTP se convierte rápidamente en FadAGDP, su forma inactiva (Yu et al., 1996), disminuyendo el crecimiento del micelio (Seo et al., 2005; Yu, 2006; Rosén, 1999), y desencadenando el desarrollo asexual de conidióforos (Park y Yu, 2012; Yu et al., 1996) y síntesis del metabolito secundario, tal como se observó en $A$. nidulans.

Por otra parte, y de manera contraria, Tag y colaboradores (2000) encontraron que mutantes con activación dominante del alelo fadA ( $f a d A^{G 42 R}$ ), es decir, expresión constitutiva del gen fadA, en Fusarium sporotrichioides, aumentó la producción de micotoxinas de tricoteceno (TR) y alteró la expresión del gen TR, al igual que en $A$. nidulans, estimuló la transcripción de un gen del clúster de genes de PN y elevó su producción. Así, FadA tuvo papeles opuestos en la regulación de la biosíntesis de un potente antibiótico (PN) y una micotoxina letal (ST) en $A$. nidulans, revelando que una proteína $G$ define un punto de control importante para la expresión diferencial de los metabolitos secundarios de hongos y entre otros géneros fúngicos. Estos datos proporcionan evidencia que sugiere que la orientación de las vías de transducción de señal de la proteína $\mathrm{G}$ como un medio para controlar o prevenir la producción de una única micotoxina podría tener consecuencias graves no deseadas con respecto a la producción de otros metabolitos secundarios.

En esta tesis se estudió a detalle la expresión del gen laeA, un regulador global de metabolitos secundarios. Se observó un comportamiento ligeramente similar de la expresión del gen laeA al observado en fadA. Lo interesante de resaltar es que se halló una alta expresión de lae $A$ al final de la trofofase en ambos sistemas de cultivo, aunque más en FL (a las 18 h), desencadenando así más adelante el inicio de la producción del metabolito secundario (lovastatina) y otras vías dependientes de la misma, evidenciando la activación de estos mecanismos regulados por LaeA. Sorprendentemente, se observó que en idiofase, la expresión del gen laeA fue regulada negativamente al hallarse casi nula la expresión de la misma (eso se observó en Northern Blot, sin embargo, en RT-PCR si se observó una ligera expresión a las 72 h), cuando se esperaba que su expresión fuera mayor que en la trofofase, ya que se sabe el papel primordial de este regulador en la producción de metabolitos 
secundarios. También es muy importante resaltar que la expresión de laeA en trofofase fue inesperada, por lo que se interrogó, si esta proteína tiene alguna función relevante en la fase de crecimiento, ya que está siendo transcrita desde el inicio, observó una relación positiva con FadA. Pero, siendo LaeA un regulador del metabolismo secundario, es evidente que en esta fase de crecimiento el metabolito secundario no se produce (lovastatina), por lo que se especuló, que en la trofofase, LaeA tiene un papel importante sobre el crecimiento y/o es regulada post-transcripcional o post-traduccionalmente de una manera importante.

Un estudio de Bok y Keller (2004) mostró que PKA regula negativamente la expresión de laeA. En esta tesis se encontró cierta correlación negativa de estos dos componentes en la trofofase, en ambos sistemas de cultivo, particularmente en FS. En FS, cuando fue muy elevada la actividad específica PKA (18 h) se observó muy baja expresión de laeA, y cuando cae drásticamente la actividad PKA (21 h) la expresión de laeA aumentó. Mientras que en FL, en trofofase, cuando se observó muy baja actividad específica PKA, la expresión de laeA fue muy elevada (18 h). Sin embargo, en idiofase, no se encontró tal correlación, ya que la actividad específica PKA no fue tan elevada y fue similar en ambos sistemas de cultivo, y la expresión de laeA fue inferior a la observada en la trofofase, por lo que se sugirió que en idiofase, existe otro mecanismo por el que la expresión del gen lae $A$ está siendo regulada negativamente.

Referente a esto, Shimizu et al. (2003) y Bok y Keller (2004) encontraron en A. nidulans que el control transcripcional de PKA sobre afIR fue mediada por LaeA, y la expresión de laeA fue regulada negativamente por AfIR mediante un mecanismo de retroalimentación, así como regulada negativamente por PKA y RAS (ambos también regulan transcripcional y posttranscripcionalmente aflR). Es posible que algo similar esté sucediendo en idiofase con la expresión de lae $A$, es decir, fue regulada negativamente por LovE (un factor transcripcional similar que AfIR) por retroalimentación, ya que se observó baja expresión de laeA, cuando hubo una acumulación elevada del transcrito lovE, siendo mayor en FS.

Debido a que LaeA está corriente arriba del clúster biosintético de lovastatina, se pensó, debería tener un comportamiento paralelo con el gen lovE por estar ambos involucrados con el metabolismo secundario, sin embargo, no fue lo que se obtuvo. Se encontró un comportamiento inverso de la expresión de lovE con la expresión de laeA. La acumulación del transcrito de lovE sólo se dio a niveles altos en la idiofase (42 h y 72 h) en ambos sistemas de cultivo (20\% más en FS) y un poco a las 21 h en FL. 
Respecto a ello, previamente se llevaron a cabo estudios moleculares en nuestro grupo de investigación para establecer las causas de la mayor producción de lovastatina en FS, en relación con la FL. Los resultados mostraron que efectivamente la mayor producción en FS fue, al menos parcialmente, debido a una transcripción más alta de sus genes biosintéticos, específicamente 4.6 veces más alto del nivel de factor de transcripción lovE. Así que, la alta expresión de lovE en idiofase obtenida en los resultados de esta tesis, concuerda con BarriosGonzález (et al., 2008).

Por otra parte, tal parece que ambos genes laeA y lovE, tuvieron comportamientos inversos en su expresión. Keller et al. (2005) encontró que en mutantes de $A$. nidulans con $\triangle l a e A: L O V_{+}$, a las $24 \mathrm{~h}$ no hubo expresión lógica de laeA pero sí se observó alta expresión de lovE y poca expresión en demás tiempos, y en mutantes $\mathrm{OE}:: / a e A: L O V+$ sí hubo más expresión de lovE a lo normal observado en cepa WT:LOV+. Sin embargo, estos resultados no se observaron de manera específica y detallada por los autores ya que su interés fueron otros genes involucrados en la biosíntesis de ST. Además, fueron realizados en caja Petri, análisis no tan comparables con nuestros experimentos. Sería lógico esperar una correlación en transcripción, pero no se observó así en los resultados de esta tesis, por lo que se sugirió existe una regulación post-transcripcional en idiofase, o incluso en la forma que LaeA regula a nivel epigenético, es posible que sea muy vital la accesibilidad de esa parte de la cromatina en trofofase por otros genes importantes, y después ya no sea tan necesaria.

La expresión de laeA, no cabe duda, fue controversial. Referente a esto y basado en estudios de micro arreglos de Perrin et al., 2007, encontraron que la supresión de laeA afectó la expresión de $9.5 \%$ de genes en $A$. fumigatus, incluyendo genes requeridos para la producción de metabolitos secundarios (Bok y Keller, 2004). Mientras que en A. flavus, dio como resultado la anulación de la producción de AF, detectándose la expresión de algunos genes tempranos implicados en la biosíntesis de AF pero ninguno de los genes biosintéticos tardíos (Kale et al., 2008). Y curiosamente, mutantes con supresión de laeA $(\Delta / a e A)$ fueron capaces de producir ST en A. nidulans (Reyes-Domínguez et al., 2010). También, mutantes $\triangle l a e A$ en $A$. flavus resultó en la pérdida de hidrofobicidad y otros cambios en el desarrollo que afectó la habilidad del hongo a producir AF (Chang et al., 2012) y cambios en la superficie celular que pudieron afectar la señalización de luz (Bayram et al., 2010; Rodríguez-Romero et al., 2010; Ruger- 
Herreros et al., 2011) que es necesaria para la iniciación del desarrollo y la señalización de la proteína G (Tag et al., 2000).

Queda claro que LaeA tiene otras funciones, aún en la fase de crecimiento, y que incluso su función en la producción de metabolitos secundarios puede ser substituida. Tal como encontraron Shaaban et al. (2010), al sobreexpresar el gen rsmA de A. nidulans, este fue capaz de compensar parcialmente la pérdida de LaeA y VeA, restaurando la producción de ST y la activación transcripcional de genes biosintéticos en cepas $\Delta v e A$ y $\Delta l a e A$. Sin embargo, las disfunciones del desarrollo sexual de las cepas no pudieron ser rescatadas. Por otra parte, se encontró por Bayram y colaboradores (2008), que LaeA y las dos proteínas de la familia velvet, VeA y VelB son parte de un complejo trimérico que es esencial para coordinar el metabolismo secundario y el desarrollo en la oscuridad. VelB y VeA son esenciales para la formación de cuerpos de fructificación, mientras que LaeA es esencial para formar células Hülle sexuales (tipos de células específicas del desarrollo) y de apoyo a la formación de esporas asexuales en un entorno apropiado, tal como la luz. LaeA además de ser un regulador global para el metabolismo secundario, presumiblemente modula su actividad con las proteínas de la familia velvet, VelB y VeA, durante el desarrollo en la oscuridad (Bayram et al., 2008; SarikayaBayram et al., 2010). Todo esto expuesto, refleja que LaeA a nivel molecular, es mucho más que un regulador global metabolismo secundario y desempeña un papel clave en el control del desarrollo en la luz en $A$. nidulans mediante el control de cantidad y modificación de las proteínas de la familia velvet (Bayram y Braus, 2012) y más funciones aún no identificadas, sobre todo en el crecimiento vegetativo.

Siguiendo con el análisis de la tesis, el patrón de expresión de fadA también se comparó con la expresión de lovE. En ambos sistemas de cultivo, la expresión de fadA fue claramente inversa a la de lovE. Por lo que se propuso una regulación negativa de FadA hacia el gen lovE. Algo similar a lo que observó Keller y colaboradores (2005), donde como conclusión de estudios genéticos, propusieron que FadA regula negativamente, al menos en parte, a afIR en A. nidulans. Se sugirió en esta tesis, ser AfIR similar a LovE, en el sentido de ser factores transcripcionales específicos del clúster biosintético (uno de AF y el otro de lovastatina).

En relación con componentes corriente abajo en la vía, se sabe que FadA activa el adenilato ciclasa, por lo que incrementa los niveles de AMPc en la célula, y este compuesto activa PKA. Shimizu y Keller (2001) y Shimizu et al. (2003) mostraron que PkaA (isoforma de la subunidad 
catalítica PKA) reprime la expresión de genes biosintéticos de ST. Esto, mediante la regulación transcripcional negativa de la expresión de aflR y también por la regulación post-traduccional (fosforilación) de la proteína AfIR, debido a 3 sitios específicos de fosforilación de PkaA en AfIR en A. nidulans.

Con estos antecedentes se sugirió que en FS, durante la trofofase, no es FadA (ya que se observó generalmente con expresión baja), sino PKA la que reprime los genes biosintéticos de lovastatina por regulación transcripcional de lovE. Es inclusive posible que PKA ejerza una regulación post-traduccional de LovE (en forma análoga a la de AfIR).

\section{Estudio de los componentes principales de la vía AMPc-PKA: Concentración de AMPc y Actividad PKA}

Para conocer la relación entre la expresión de fadA, niveles de AMPc y actividad de PKA, se determinó la concentración de este segundo mensajero y la actividad específica PKA.

En ambos sistemas de cultivo, se encontró un comportamiento similar entre la concentración de AMPc intracelular y la actividad PKA, siendo el comportamiento de ambos componentes opuesto al patrón de expresión fadA, y siendo distinto tanto en FS como FL.

En primera instancia, en la FS, se observó que la concentración de AMPc fue alta y la actividad específica PKA muy elevada en trofofase (18 h), cuando la expresión de lovE fue casi nula y la expresión de laeA fue baja. Al pasar a la idiofase, la concentración de AMPc bajó drásticamente al igual que la actividad de PKA, cuando se expresó el gen lovE y procedió la biosíntesis de lovastatina. La concentración de AMPc permaneció baja durante toda esta fase de producción, se confirmó así, una relación positiva entre AMPc y PKA, y relación negativa con la expresión de lovE en la producción de lovastatina.

En contraste, en $\mathrm{FL}$, se encontró en trofofase una baja concentración de AMPc, y poca actividad específica PKA. En idiofase, la concentración de AMPc subió, mientras que la actividad de PKA ligeramente aumento, al mismo nivel que en la FS.

El hecho de que, en FL la concentración de AMPc haya sido relativamente baja en trofofase es inesperado, pues se esperaba un comportamiento similar al de la FS. También, que dicha concentración subiera en idiofase, teniendo relación ligera con la actividad de PKA, no 
teniendo sentido con la expresión de lovE y la síntesis de lovastatina. Se sugirió que existe la remota posibilidad de que, en FL, el AMPc regule en forma distinta la biosíntesis de lovastatina. Respecto a ello, el único estudio que apoya en cierto modo esta explicación es lo realizado por Tice y Buchanan (1981), que sugiere un papel regulador positivo de señalización de AMPc en la síntesis de AF en $A$. parasiticus, donde la adición de AMPc o DcAMP (análogo de AMPc:dibutiril-AMPc) a un medio de crecimiento, dio lugar a una estimulación dependiente y niveles elevados de acumulación de AF en cultivo líquido estacionario; el tratamiento resultó en un aumento de 100 veces en AMPc/DcAMP intracelular. Estos análisis sólo están acordes a lo que se obtuvo en esta tesis, en idiofase en la FL, cuando una elevada concentración de AMPc intracelular dio lugar a la producción de lovastatina.

Con los datos obtenidos en esta tesis, respecto a las mediciones de AMPc intracelular, expresión de fadA y actividad específica PKA y realizado un análisis conjunto, se observó un comportamiento distinto de la expresión de fadA con la concentración de AMPc y actividad específica PKA en cualquier tiempo en ambos sistemas de cultivo, teniendo algunas discrepancias (específicamente en $\mathrm{FL}$ ) con informes ya declarados y discutidos por Roze et al. (2004) sobre el papel de FadA, AMPc y PKA en A. parasiticus y con el esquema regulatorio propuesto para $A$. nidulans (Shimizu y Keller, 2001).

Se pudo concluir con esto, que los resultados de esta tesis sugieren, que FadA inhibe la biosíntesis de lovastatina, esto queda claro, particularmente en FL. Mientras que, en FS, al haber detectado una expresión baja y constante de fadA en ambas fases (excepto a las $21 \mathrm{~h}$ ). Se consideró que no entra en conflicto referido sobre el funcionamiento de FadA, donde su transcripción indica la participación de estas proteínas $\mathrm{G}$ en la vía de transducción con una percepción hacia un ambiente sólido. Esto valdría la pena investigarlo a mayor profundidad, por su potencial importancia en el conocimiento de la transducción de señales del ambiente sólido, de lo cual se sabe poco, y que da como resultado la fisiología del medio sólido.

En cuanto a los componentes corriente abajo, AMPc y PKA, en FS funcionaron en forma coherente con el modelo del grupo de Keller. Es decir, en trofofase, la concentración de AMPc y actividad de PKA fueron altas, bajando ambos drásticamente en idiofase, coincidiendo con el inicio la expresión de lovE y biosíntesis de lovastatina. También, más tarde con la expresión de brlA y la conidiación. Sin embargo, en FL, sólo la expresión de fadA coincidió con dicho modelo. Sin embargo, la actividad de PKA, fue baja en trofofase y subió ligeramente en idiofase 
(a niveles más o menos comparables a los de FS en esa fase). Aunado a este comportamiento inesperado en FL, la concentración de AMPc fue intermedia en trofofase y alta en idiofase, como se discutió arriba, fue controversial y será objeto de más estudio. En un futuro habría que profundizar en el estudio de las diferencias encontradas en FS y en FL, particularmente la alta concentración de AMPc en idiofase.

De manera general, con los resultados de esta tesis, se propuso que FadA participa en la activación del adenilato ciclasa, incrementando el nivel intracelular de AMPc, el cual activa la PKA en $A$. terreus. Se pudo concluir que FadA/AMPc/PKA regulan la síntesis de lovastatina y conidiación a través de mecanismos de regulación similares a los descritos para la síntesis de micotoxinas $A$. nidulans y $A$. parasiticus (Shimizu y Keller, 2001; Shimizu et al., 2003).

Respecto a la expresión del regulador global de metabolitos secundarios (LaeA) ya se había comentado un comportamiento similar al de la expresión de $\operatorname{fad} A$, en el sentido de una expresión alta (aunque muy puntual) en trofofase y baja expresión en idiofase, en ambos sistemas de cultivo. Se propuso que la expresión de laeA en la idiofase, es regulada posttranscripcional o post-traduccionalmente. Lo que sí es claro es que FadA en la trofofase, reguló negativamente la expresión de lovE, y por ende los niveles del transcrito lov $F$, gen que transcribe para una policétido sintasa del clúster biosintético de lovastatina, confirmando una relación estrecha y positiva de LovE y LovF en la producción de lovastatina en idiofase.

Otro factor componente involucrado en la vía de señalización es el factor de transcripción de la conidiación, brlA. Este se expresó solamente en FS, claramente a las $72 \mathrm{~h}$ en la idiofase, coincidiendo con la observación de esporas en FS después de 72 h. En este tiempo, la expresión de fadA fue la más baja, por lo que los resultados de esta tesis están en concordancia con lo reportado por Hicks et al. (1997) y Roze et al. (2004) en A. nidulans y $A$. parasiticus. Indicando que FadA (Ga) estimula, al menos en parte, la inhibición de conidiación y biosíntesis del metabolito secundario. Así, el estudio a nivel de transcripción en esta tesis sugiere que FadA regula de forma negativa, además de la expresión de lovE también la expresión de $b r l A$, es decir, la producción de lovastatina y conidiación en $A$. terreus. Es decir, que la alta expresión de fad $A$ (en trofofase) inhibe la conidiación y la producción de lovastatina. Cuando existe una regulación negativa de $\mathrm{fad} A$ en la idiofase se activan dichos procesos, confirmando la función de FadA en la supresión de estos mecanismos en $A$. terreus. Los 
resultados de esta tesis son coherentes también con los estudios de Shimizu y Keller (2001), donde una mutante con expresión constitutiva de $\operatorname{fad} A$ (alelo $\operatorname{fad} A^{\mathrm{G} 42 \mathrm{R}}$ ) tuvo pérdida en la biosíntesis de ST y esporulación asexual. Este mismo alelo reguló negativamente la síntesis de AF y conidiación dando un fenotipo suave y esponjoso (fluffy) en $A$. flavus.

Debido a que PKA es un potencial constituyente corriente abajo de la señalización Ga-GTP, fue examinado como un vínculo en la cascada de señalización que media la represión de FadA en la expresión de aflR y brlA en $A$. nidulans por Brodhagen y Keller (2006). Otro estudio por Bencina y colaboradores (1997) mostraron que la sobreexpresión moderada de pkaC en $A$. niger, afectó el crecimiento y las características de esporulación. Esto también tuvo concordancia con los resultados encontrados en esta tesis, donde una baja actividad específica PKA en la idiofase en FS, dio lugar a una mayor conidiación en $A$. terreus, lo que no se detectó en FL. Roze y colaboradores (2004) también encontraron que el AMPc exógeno/DcAMP y la activación de PKA tuvieron efectos reguladores sobre conidiación y síntesis de AF.

De hecho, los datos de Adams y colaboradores (1998) y Shimizu y Keller (2001), mostraron que PKA afectó la expresión de brlA. Cuando pkaA fue sobreexpresada, la expresión transcripcional de afIR y $b r l A$ no fueron inducidos, lo que resultó en inhibición de producción de micotoxinas y desarrollo de conidióforos. Respecto a ello, se encontró en esta tesis, que en FS, en idiofase específicamente, cuando hubo baja concentración de AMPc y baja actividad PKA, hubo alta expresión de brlA y subsecuente conidiación en $A$. terreus, mientras que en FL, al haber alta concentración de AMPc y actividad PKA, hubo expresión nula de brlA y poca conidiación.

Referente a otros transcritos involucrados no tan directamente, pero que convergen en la vía AMPc-PKA, está el gen atfB y el gen $m s n A$, y éstos mostraron comportamiento muy diferente en cuanto a patrones de transcripción. El gen atfB, en general mostró mayor expresión en FS que en FL.

En FS, la expresión del gen atfB fue alta en trofofase y relativamente baja en la idiofase. Mientras que en FL, se detectó una alta expresión sólo a las $18 \mathrm{~h}$, y después disminuyó a un nivel menor a las $21 \mathrm{~h}$ y se mantuvo casi constante hasta las $72 \mathrm{~h}$. Con este comportamiento pareciera que FadA influyó de manera positiva la expresión de atfB. Este patrón de

Tesis de Doctorado en Biotecnología 
transcripción no fue coherente con una regulación positiva de AtfB sobre lovE y los otros genes de biosíntesis de lovastatina. Tal como lo refirió Roze y colaboradores (2011), donde hallaron que la vía $\mathrm{AMPc/PKA}$ regula la biosíntesis de $\mathrm{AF}$ en $A$. parasiticus, al menos en parte a través de AtfB. Sus resultados sugirieron que AtfB activa los promotores de genes de AF que llevan sitios CRE y, además, genes antioxidantes. En su trabajo encontraron que se expresa el gen atfB en la fase de crecimiento tardía durante la formación de conidios en medio sólido. Ampliando esto, el grupo de Linz propuso un modelo donde una red de regulación de factores de transcripción simultáneamente activa los genes de defensa contra el estrés oxidativo (AtfB, Yap1, MsnA, SrrA) y los de biosíntesis (AfIR). De hecho, proponen que las AF contribuyen por su capacidad antioxidante. (Hong et al., 2013; Roze et al., 2004). Es más, el mismo grupo ha demostrado la unión de AtfB a promotores de varios genes de biosíntesis de AF, incluidos fas1 y ver-1, así como genes de respuesta a estrés como cat1 (específico del micelio) y Mn sod (mitocondrial) (Hong et al., 2013b).

Todo esto arriba mencionado contrasta con los resultados obtenidos aquí. Es posible que, en A. terreus, AtfB no participe en la biosíntesis de lovastatina, o que simplemente sea regulado en trofofase y sea activado en idiofase. Por otro lado, el patrón de transcripción de atfB coincide con el de otras defensas antioxidantes como yap 1 y sod1, en el sentido de que se regulan a la baja en idiofase (Miranda et al., 2013; 2014), colaborando a la acumulación de especies reactivas de oxígeno en idiofase. Sin embargo, en este caso atfB conserva un cierto nivel de transcripción, con lo cual todavía sería posible un papel de regulador positivo, activando promotores que tengan sitios $\mathrm{CRE}$, de genes biosintéticos de lovastatina y conidiación en $A$. terreus.

Referido al factor transcripcional MsnA, un homólogo de Msn2 y Msn4 de S. cerevisiae, es un factor requerido para la transcripción de genes que codifican proteínas con funciones de protección al estrés. Tanto en FS como en FL, msnA se expresó en ambas fases de crecimiento. Con poca expresión a las $18 \mathrm{~h}$ y mayor a las $42 \mathrm{~h}$ en FL. En FS, la expresión importante fue a las $72 \mathrm{~h}$. Esta mayor expresión en idiofase concuerda con el papel teórico de MsnA. Se ha propuesto que MsnA se activa en idiofase por la regulación a la baja de la vía AMPc-PKA, activando los genes antioxidantes y también las AF. Simultáneamente, se regula positivamente la vía SAPK/MAPKinasa, resultando de igual manera en que AtfB y SrrA se unen a promotores de genes antioxidantes y biosintéticos (Hong et al., 2013). 
En un análisis in sílico del promotor de laeA y lovE se encontró secuencias putativas de reconocimiento de los factores de transcripción MSN2/4, por lo que sería posible que dichos factores influencian sobre la expresión de lae $A$ y lov $E$ de acuerdo con la respuesta general de estrés, y por tanto inhibición de la respuesta general de estrés.

\section{SOBREEXPRESIÓN DE laeA (SE::laeA): ASPECTOS BÁSICOS Y ESTRATEGIAS DE MEJORAMIENTO GENÉTICO}

Con el fin de comprender mejor el papel de LaeA en la producción de lovastatina, y otras características relacionadas con la vía cAMP-PKA, en FS y FL, se estudió el efecto de la sobreexpresión del gen laeA.

Debido a que en la parte anterior se encontraron diferencias en el comportamiento de algunos componentes de esta vía de señalización, sugiriendo que esta vía percibe señales del medio sólido, se tuvo el objetivo adicional de evaluar la sobreexpresión de laeA como una posible estrategia de mejoramiento genético para generar cepas especiales para FS.

Dado que el éxito en mantener una industria competitiva de fermentación depende en gran medida en la mejora continua de cepas de producción, los métodos de mejoramiento genético se consideran tecnologías importantes en este campo.

Debido a que, LaeA (regulador global para la síntesis de metabolitos secundarios) está asociada con la cascada de señalización AMPc-PKA la cual detecta señales del medio ambiente, su sobreexpresión podría generar diferentes efectos en FS. Además, se obtuvo evidencias en esta tesis, que algunos componentes de esta vía se comportan de manera diferente en FS (como expresión del gen fadA y el comportamiento de niveles de AMPc y PKA). Por lo tanto, se propuso la sobreexpresión del gen lae $A$ como un enfoque de mejoramiento genético molecular para generar cepas sobreproductoras de lovastatina de $A$. terreus, especialmente adecuadas para la FS. Se realizaron dos estrategias alternativas para la sobreexpresión del gen laeA (SE::/aeA): a) con su propio promotor y b) a partir de un promotor constitutivo.

El efecto positivo de SE::laeA en la producción de lovastatina ya se había reportado antes, pero en diferentes cepas y encaminados a diferentes objetivos. Como Kosalková et al. (2008), SE::IaeA en $P$. chrysogenum, con el plásmido pIBRC43 bajo un promotor fuerte ( $g d h$ de $A$. 
awamori), obteniendo sólo un 25\% de incremento en la producción de PN. Bok y Keller (2004) construyeron una cepa de $A$. nidulans con su gen laeA y el clúster parcial de genes de lovastatina proveniente de $A$. terreus, obteniendo incrementos importantes en la producción de PN y lovastatina en tiempos donde la cepa silvestre no mostraba actividad, incrementando $\sim 400 \%$ de monacolin J (intermediario de lovastatina). También SE::laeA de $A$. nidulans con un promotor inducible alcA en $A$. terreus, condujo un incremento de 400 a $700 \%$ en la producción de lovastatina. Sin embargo, es importante notar que, en este estudio, había un propósito diferente y el medio utilizado no era un medio específico para la producción de lovastatina (medio mínimo de glucosa) ni el metabolito secundario se cuantificó con precisión, fue un análisis semi cuantitativo realizado en placas de cromatografía en capa fina (TLC); y la FL sólo se realizó hasta las $36 \mathrm{~h}$ de crecimiento. En contraste, los resultados de esta tesis fueron encaminados a hallar transformantes capaces de sobreproducir lovastatina de manera tipo industrial, bajo las condiciones de producción más aptas para el hongo. Debido a esto, los resultados no son comparables.

Aunque se habían reportado estudios sobre efecto de la sobreexpresión de laeA en la biosíntesis de lovastatina o expresión de algunos genes de biosíntesis, existen varios hallazgos y aspectos novedosos en esta tesis. En primer lugar, nunca se había sobreexpresado el gen laeA (SE::/aeA) de A. terreus en él mismo. Otro es la utilización de dos estrategias para SE::/aeA: con su propio promotor y un promotor constitutivo. Tampoco había sido reportada una medición cuantitativa (HPLC) de la producción de lovastatina, lo cual permitió evaluar con precisión el efecto de incrementar el número de copias de este gen. Otro aspecto original es la comparación del efecto de ambas estrategias (SE::laeA) en FS y FL y hallar la mejor técnica de mejoramiento genético de la cepa para cada sistema de cultivo. $Y$ finalmente caracterizar las transformantes buscando efectos sobre la conidiación, morfología, crecimiento, resistencia a estrés, y sobre la expresión de otros genes importantes en la vía de señalización AMPc-PKA, para entender mejor la fisiología del medio sólido.

Se sabe que un mayor nivel de expresión del gen de interés es logrado por la introducción de copias múltiples como se realizó en esta tesis (SE::/aeA), aunque este aumento de copias frecuentemente debe conducir al incremento de los niveles de actividad del gen introducido, particularmente al incremento de lovastatina, aunque una correlación lineal no es usualmente observada, debido al afecto del sitio de integración y a las limitaciones de la regulación y del 
procesamiento post-traduccional. Por lo anterior, el uso de promotores fuertes o constitutivos, como el utilizado en nuestro trabajo como segunda estrategia (promotor constitutivo gpd de $A$. nidulans), puede resultar en un sistema de expresión eficiente. Pero, debido a que la introducción de genes con expresión constitutiva puede ocasionar problemas metabólicos en el hongo, se optó por además sobreexpresar laeA con su propio promotor y encontrar cuál estrategia es mejor para obtener cepas sobreproductoras, principalmente para FS.

En la transformación es posible lograr la recombinación genética, es decir, generar nuevas combinaciones de genes. Verdoes y colaboradores (1995) mostraron que transformantes obtenidas por cualquier método, sus secuencias introducidas son integradas establemente en el genoma por recombinación homóloga o heteróloga. La recombinación heteróloga es un modo predominante de integración en hongos filamentosos; mientras que la integración homóloga llega a ser posible sólo cuando hay longitudes extensas de secuencias homólogas entre el vector y el genoma (en relación con levaduras o $E$. coli). En $A$. terreus, no se ha reportado la eficiencia de la recombinación homóloga. Sin embargo, Barrios-González et al. (2003) indican que en transformantes de hongos que no tienen buena recombinación homóloga, el vector puede integrarse en diferentes sitios en el genoma, siendo algunos de estos sitios poco favorables para la expresión del gen, o incluso dañar algún gen importante. Sin embargo, una preselección simple y rápida de las mejores productoras de lovastatina mediante fermentación en cilindro de agar (FCA) y bioensayo, muestra los casos donde el gen se integró en un sitio adecuado "neutro" del cromosoma, evitando así las transformantes falsas. Esta fue la estrategia usada en esta tesis, donde se preseleccionaron las transformantes por su producción en fermentación en cilindro de agar (FCA), ya optimizada por Baños et al., (2009). De esta manera, se obtuvieron datos de producción en FCA (con los cuales se realizó una preselección), seguida de una producción en FS y FL, para realizar así una evaluación y selección de las mejores transformantes.

\section{Producción de lovastatina en FCA (preselección)}

La primera estrategia basada en la construcción pUAMTPlaeA, SE::laeA con su propio promotor, resultó en la obtención de 21 transformantes resistentes a fleomicina $(120 \mu \mathrm{g} / \mathrm{mL})$, de las cuales, evaluadas por FCA, sólo 10 transformantes mostraron mayor producción de lovastatina respecto a la parental (>220 $\mu \mathrm{g}$ lov/mL vs $190 \mu \mathrm{g}$ lov/mL, respectivamente). Mientras que, en segunda estrategia basada en la construcción pUAMTPlaeAcons, 
expresando laeA constitutivamente, se obtuvieron sólo 12 transformantes resistentes a fleomicina, de las cuales, 10 transformantes mostraron mayor producción de lovastatina que la parental en FCA (>190 $\mathrm{g}$ lov/mL vs $190 \mu \mathrm{g}$ lov/mL, respectivamente). Las transformantes sobreproductoras de lovastatina en FCA fueron más abundantes en la población de transformantes con promotor constitutivo: 10 de 12 vs. 10 de 21 en la población de transformantes con propio promotor del gen, (Pérez et al., 2015). Esto ya sugería que la estrategia de usar un promotor constitutivo generaba mayor proporción de sobreproductoras.

\section{Producción en FS y en FL (Selección)}

Se prosiguió a la evaluación de la producción de lovastatina de las transformantes preseleccionadas en ambas estrategias en ambos sistemas de cultivo, realizando FS y FL en un solo punto (día 7). Un aspecto intrigante que se obtuvo es que una proporción importante de las transformantes mostró una fuerte disminución en los niveles de producción en FL (inferior a la parental): $40 \%$ de las transformantes con propio promotor, y un sorprendente $90 \%$ con promotor constitutivo.

Este fenómeno no se observó en FS. La razón de esto no está clara, pero parece que la fisiología de FL es más vulnerable a los sitios de integración inconvenientes.

Es importante señalar que, presumiblemente a causa de la integración del gen lae $A$ en diferentes sitios, las transformantes mostraron diferencias en el nivel de producción y otras características. De esta manera, la mayoría de las mejores transformantes mostraron buen rendimiento en FS o en FL. Es decir, las mejores sobreproductoras en FS no eran las mejores en FL y viceversa. Aunque la razón de esto no está clara, esto concuerda con las conclusiones de otros estudios sobre la producción de enzimas o metabolitos secundarios mencionados anteriormente y con el poco conocimiento de la fisiología del medio sólido.

Sin embargo, un buen desempeño en ambos sistemas de cultivo, aunque no es común, se pueden obtener. Este fue el caso de T9laeA, mejor transformante (SE::/aeA con su propio promotor) en FS y la segunda mejor en FL de esta estrategia, o la T6laeA con el aumento de la producción a nivel medio en ambos sistemas de cultivo.

Las demás mostraron rendimientos contrastantes, como T3laeA y T2laeA con muy buenos niveles de producción en FS, pero muy malos rendimientos en FL. Del mismo modo, T2laeA y T4laeA, con producciones de nivel medio en FS y muy malos rendimientos en FL. Respecto a 
la segunda estrategia (SE::laeA promotor constitutivo), sólo la T5laeAcons mostró un excelente rendimiento en la producción en FL y nivel medio en FS. La T2laeAcons que fue la mejor en FS, pero tuvo una disminución del 10.9\% en FL, y la mayoría prácticamente mostraron buenas producciones en FS, y reducciones desastrosas en la producción en FL. Curiosamente, ninguna transformante mostró una disminución de la producción en FS.

\section{Sobreexpresión de laeA como método de mejoramiento genético.}

Para evaluar qué estrategia era más conveniente para obtener cepas sobreproductoras para FS, dos factores fueron tomados en cuenta: porcentaje con que estas mutantes se pueden obtener (abundancia de la población transformante), e incremento en la producción.

Con esta perspectiva, sobreexpresando lae $A$ con un promotor constitutivo resulto una estrategia más adecuado para obtener cepas sobreproductoras de lovastatina en FS. Esto, debido a la muy alta abundancia de estas mutantes dentro de la población transformante (100\%). Además, la mejor transformante mostró un incremento en la producción de 63\%. Para FL el panorama fue diferente, ya que sólo el $10 \%$ de las transformantes fueron sobreproductoras en FL, la mejor y única obtuvo un incremento del $62 \%$.

La población de transformantes que sobreexpresan laeA con su propio promotor contuvo 90\% de sobreproductoras para FS. Sin embargo, la mejor productora en FS mostró un incremento de producción solo del $47 \%$. En cuanto a $\mathrm{FL}$, esta estrategia produjo una población de transformantes con un $50 \%$ de sobreproductoras, que es mucho mayor que en la estrategia anterior. Además, la mejor transformante mostró un incremento de $82 \%$.

En términos generales, los resultados obtenidos mostraron que la $\mathrm{SE}:$ :laeA, bajo cualquiera de las dos estrategias usadas, es un excelente método para generar cepas sobreproductoras (lovastatina) en FS. Bajo ciertas circunstancias, el enfoque también se ha realizado correctamente para obtener cepas sobreproductoras de FL. El que se haya obtenido excelentes resultados de sobreproductoras sobre todo en FS se debe quizás a que, el hongo en FS se adapta mejor a la señalización desde el inicio de su crecimiento, pero al evaluarlas éstas mismas en FL, quizás el sitio de integración del gen laeA es más crítico para producir lovastatina en medio líquido lo que se tradujo en menos incrementos o disminuciones, igual y a que se transduce la señalización con menos claridad afectando la expresión de laeA. Por lo 
que se demostró que, la sobreexpresión del gen regulador global lae $A$ en $A$. terreus es un excelente método para generar cepas sobreproductoras de lovastatina para FS, pero no tanto para FL. Ya que LaeA es un regulador global del metabolismo secundario, es muy probable que este método pueda ser aplicado a otros metabolitos secundarios de hongos para generar cepas sobreproductoras de FS.

Muy pocos trabajos han explorado estrategias de mejora genética molecular para obtener cepas especiales para FS. En el campo de la producción de metabolitos secundarios, Campos y colaboradores (2008) aumentaron la dosis de todo el clúster de genes de PN en 2 cepas de $P$. chrysogenum. Las transformantes mostraron importantes aumentos en las producciones de PN, más en FS, en relación con la obtenida en FL. Debido a que el incremento de producción en FS fue mayor, los autores discuten que, aparentemente, los genes que permiten un buen rendimiento en FS, se conservan mejor en cepas que son más semejante a la parental.

\section{Caracterización de las mejores transformantes}

Volviendo a la presente tesis, se seleccionaron las mejores transformantes, 2 de cada estrategia, una para cada sistema de cultivo, Las mejores para FS: T9laeA y T2laeAcons; y las mejores para FL: T1laeA y T5laeAcons. Estos fueron posteriormente caracterizados en estudios cinéticos, donde los rendimientos alcanzados de lovastatina fueron mucho más altos que los encontrados en etapas previas. La razón fue que se desplazó el tiempo máximo producción. Los resultados confirmaron que la mejor transformante en FS fue la T2laeAcons, con promotor constitutivo, el cual extendió su etapa de producción al día 9 (la parental produce hasta el día 5), alcanzando $30.6 \mathrm{mg}$ de lovastatina/gss. Esto representó un 104\% de incremento en la producción. Esta transformante además que obtuvo un alto incremento en la producción, obtuvo una concentración de lovastatina superior en relación con las reportadas para FS en artículos publicados. Baños y colaboradores (2009) reporta una máxima de producción de lovastatina de $19.95 \mathrm{mg} / \mathrm{gss}$ en FS en soporte inerte artificial, mientras que Valera y colaboradores (2005) reportaron una producción de $16.78 \mathrm{mg} / \mathrm{gss}$ con una cepa mejorada en FS con salvado de trigo.

Las transformantes seleccionadas para FL, T1laeA y T5laeAcons, también extendieron el tiempo de producción para la biosíntesis de lovastatina desde el día 3 hasta el día 9, alcanzando en la T1laeA una alta producción de lovastatina de $0.89 \mathrm{mg} / \mathrm{mL}(102 \%$ de 
incremento en la producción). Este es un nivel de producción interesante, si se compara con otros informes sobre la mejora de cepas (Vilches-Ferrón et al., 2005; Sreedevi et al., 2011; Li et al., 2011).

Desde un punto de vista básico, era muy importante por un lado confirmar que el gen laeA realmente se sobreexpresó y por otro lado, determinar si el incremento del número de copias del gen lae $A$ en $A$. terreus tuvo un efecto sobre la producción de lovastatina y no sobre el crecimiento. Es decir, demostrar que el incremento en la producción de lovastatina fue debido a una mayor producción específica y no a un mayor crecimiento, por lo que obtuvimos las producciones específicas. Los resultados demostraron que todas las transformantes seleccionadas muestran producciones específicas superiores a la parental, es decir, que el incremento en la producción de lovastatina se debió realmente al número de copias introducidas y no al efecto de un mayor crecimiento por la manipulación genética realizada.

En esta tesis, un análisis en la expresión confirmó que el gen laeA fue realmente sobreexpresado en las transformantes seleccionadas. Todas las transformantes mostraron una expresión de laeA notablemente más alto que la cepa parental, en ambos sistemas de cultivo en particular en la trofofase (18 h). En las transformantes seleccionadas para FS, T2laeAcons y T9laeA, el gen laeA se expresó más alto que la parental, en ambas fases de crecimiento, particularmente la transformante con promotor constitutivo (T2laeAcons) fue superior en todos los tiempos (muy intensa en trofofase a las $18 \mathrm{~h}$ ) tanto respecto a la parental como a la T9laeA. Para la T9laeA, sólo hubo mayor expresión a las 18 y 120 h (5 d), en otros tiempos fue similar incluso un poco menor que la parental. Esto resulta muy interesante, ya que correlaciona y podría explicar el alargamiento de la fase de producción en estas transformantes sobreproductoras.

En las cepas seleccionadas para FL, también se comprobó que laeA se expresa más que en la parental. Sin embargo, en estas mutantes (y en este sistema de cultivo) aunque está claro que el mejoramiento en la producción de las transformantes se debió a la SE::laeA, y que los altos incrementos en la producción de lovastatina se debieron de igual manera a períodos más largos de producción en las transformantes, no pudimos encontrar correlación entre la expresión laeA en la parte final de la idiofase y la extensión del período de producción de lovastatina, ya que la expresión de laeA es baja en la idiofase. Por lo tanto, en la actualidad 
no queda claro cómo podría estar relacionada la sobreexpresión de laeA con la sobreproducción de lovastatina.

LaeA sigue siendo una proteína enigmática: a pesar de que fue originalmente identificada como un regulador global de la biosíntesis de metabolitos secundarios, se encontró posteriormente que tienen funciones importantes en otros aspectos fisiológicos como en el desarrollo y el parasitismo, entre otros rasgos (Bok et al., 2005). Actualmente distintos proyectos del laboratorio se enfocan en la identificación de las señales ambientales en cultivo sólido y sus vías de transducción que inducen los genes reguladores, factores de transcripción y los clústers de genes biosintéticos. De esta manera, fue interesante analizar cómo la $\mathrm{SE}:$ :laeA en $A$. terreus modificó algunos genes implicados en la vía de señalización AMPcPKA y cómo afectó otros aspectos fisiológicos, como el crecimiento, la conidiación, la morfología, y la respuesta al estrés. Por ello, se analizó la expresión de genes como: lovE, IovF, brlA y $m s n A$, que esperábamos se modificarán debido a la SE::laeA.

Respecto a la expresión de lovE y lovF se observó que, en algún tiempo, las transformantes tuvieron mayor acumulación de estos transcritos respecto a la parental. Así, las mejores transformantes para FL (T5laeAcons y T1laeA) y la T9laeA (mejor transformante para FS que $\mathrm{SE}:$ :laeA con su propio promotor), tuvieron mayor expresión de lovE y lov $F$ a las $72 \mathrm{~h}$, respecto a la parental. Sin embargo, la mejor transformante en FS, la T2laeAcons que SE::laeA con promotor constitutivo, tuvo un comportamiento diferente, sólo se observó un ligero incremento de expresión de ambos genes a las $18 \mathrm{~h}$, en otros tiempos fue similar incluso menor que la parental.

Sin embargo, no se encontró la correlación esperada entre la expresión de lae $A$ con los genes de biosíntesis, se pretendía encontrar en todos los tiempos analizados (sobre todo en idiofase), que fuera mayor su expresión respecto a la parental. Pero, tomando de base lo analizado en la parental, sobre un comportamiento opuesto de estos genes respecto a lae $A$, estos resultados fueron en cierta forma lógicos.

También se analizó la expresión de brlA y se observó un aumento en la T1laeA y T9laeA (transformantes con propio promotor) en la idiofase (72 h), mientras que en las transformantes con promotor constitutivo, sólo la T5laeAcons (mejor transformantes para FL) aumento un poco su expresión, mientras que extrañamente la T2laeAcons (mejor transformante para FS) 
disminuyó su expresión significativamente a las 72 h, siendo menor que la parental. Esto concuerda con el poco incremento de esporulación detectado. Evaluando el índice de esporulación de todas las transformantes preseleccionadas se encontró que, las transformantes que SE::/aeA con su propio promotor presentó aumentos muy altos en el índice de esporulación (240\% promedio), mientras que las transformantes que SE::laeA constitutivamente mostraron un aumento comparativamente menor ( $65 \%$ promedio).

El efecto de SE::laeA en la conidiación, observada en este trabajo, podría explicarse por el papel que desempeña LaeA en la interacción con el complejo velvet, relacionado con el desarrollo sexual y asexual dependiente de la luz. Se ha reportado que, en A. nidulans, LaeA controla negativamente la concentración del dímero VosA-VelB, los cuales reprime la formación de esporas asexuales (Ni y Yu, 2007; Sarikaya-Bayram et al., 2010). Y los estudios sobre $P$. chrysogenum, han demostrado que, PcLaeA, también posee una función en la diferenciación de hifas, encontrando un fenotipo hiper ramificado en mutantes $\triangle \mathrm{PclaeA}$ (Hoff et al., 2010). La supresión del gen laeA en $P$. chrysogenum, y también en $A$. fumigatus y $A$. flavus, causó la reducción de conidiación (Bok et al., 2005; Chang et al., 2012). Al parecer expresarse de más lae $A$ en la trofofase provoca cambios drásticos en la conidiación, mientras que expresarse de más en la idiofase tiene un efecto muy positivo, pero lo que es seguro, es que LaeA está íntimamente ligado con la conidiación.

Aparentemente, la conidiación es un proceso fisiológico más delicado y sofisticado que el crecimiento. Respecto a ello, nuestros resultados indicaron que la SE::lae $A$ también tuvo un efecto positivo en el crecimiento (RGR). Contrario a lo hallado sobre la esporulación, el aumento en la tasa de crecimiento radial fue similar en ambas poblaciones, es decir, en transformantes con propio promotor y con promotor constitutivo. En general, las cepas sobreproductoras industriales, las cuales han sido objeto de varios programas de mutación y selección, tienen una vitalidad reducida, expresada en una velocidad de crecimiento baja y conidiación muy reducida. En este sentido, un aumento en la esporulación y velocidad de crecimiento, obtenido como beneficios colaterales en nuestras transformantes que SE::/aeA, son ventajas adicionales de los métodos de mejoramiento genético aquí propuestos.

En el trabajo de Kosalková et al. (2008) arriba mencionado, se obtuvieron mutantes nulas del gen lae $A$ exhibiendo niveles drásticamente reducidos de PN y defectos en la pigmentación y 
esporulación. De manera interesante, los resultados de esta tesis, la SE::laeA en $A$. terreus muestran cambios en la morfología con aparición de surcos y mayor esporulación en algunas transformantes, sugiriendo que LaeA está relacionado con el tipo de crecimiento (morfología colonial) y la esporulación. Esto parece no concordar con la vía de señalización donde está involucrada LaeA (ver Figura 2), ya que ésta, es independiente pues se encuentra corriente debajo de los genes de esporulación. De hecho, el gen laeA fue descubierto buscando mutantes que habían perdido su capacidad de producir metabolitos secundarios, pero mantenía su capacidad de esporulación (Keller et al., 2005). Sin embargo, Bok y colaboradores (2005) presentaron resultados donde muestra que LaeA actúa como un regulador de expresión de genes que codifican para componentes conidiales tal como pigmentos e hidrofobinas, que contribuyen a su virulencia en $A$. fumigatus. Todo esto sugiere que debe haber otras vías en las que LaeA influencia la forma de crecimiento y la esporulación.

Por otra parte, nuestro grupo ha reportado estudios sobre otros factores relacionados con la mayor producción de lovastatina en FS (Miranda-Labra et al., 2007 y 2009), los cuales apoyan lo reportado por Baños y colaboradores (2009). Este último estudio sugiere que la capacidad de contender con el estrés osmótico y oxidativo tiende a ser importante para la producción de lovastatina en FS. Por lo que, esto fue la base de métodos de mutación y selección racional eficaces para aislar mutantes sobreproductoras especiales para FS (Baños et al. manuscrito en preparación).

Con el fin de evaluar posible relación entre LaeA y la resistencia a estrés oxidativo, se evaluó este parámetro. Se observaron diferentes fenotipos en transformantes de ambas estrategias, habiendo algunas resistentes (20\%) y el resto sensibles al estrés oxidativo. Las más resistentes a $\mathrm{H}_{2} \mathrm{O}_{2}$ con respecto a la parental, casualmente fueron las mejores transformantes que SE::laeA con propio promotor (T9 y T1laeA) en FS y FL. Las menos sensibles, fueron las mejores transformantes que SE::laeA con promotor constitutivo (T2 y T5laeAcons) en FS y FL, respectivamente. Esto llama la atención, pero no está claro si está relacionado con la sobreexpresión de lae $A$ y al promotor utilizado. Sin embargo, sí se correlacionó con la expresión de $m s n A$ en esas transformantes. En este caso, la expresión del gen $m n s A$, factor específico de respuesta al estrés, fue mayor en la T9 y T1laeA a las 72h, traducido en mayor resistencia al estrés oxidativo. Mientras que para las T2 y T5laeAcons fue todo lo contrario, menos expresión de $m s n A$, menos resistencia. 
También se evaluó la posible relación entre LaeA y la resistencia a estrés osmótico. Se encontró que las mejores transformantes para FS (T2laeAcons y T9laeA), tuvieron un efecto de sensibilidad al estrés osmótico, mientras que las mejores transformantes para FL (T5laeAcons y T1laeA), presentaron una mayor resistencia. Este puede ser un dato importante en cuanto a características para aislar a cepas sobreproductoras para uno u otro cultivo. Sin embargo, habría que profundizar y confirmar estos resultados. Interesantemente la T2laeAcos (la mayor productora de lovastatina en FS, con mejor productividad que todas en general) fue sensible tanto a estrés osmótico como a estrés oxidativo.

\section{CONCLUSIONES}

1. Comparando la FS con la FL, se encontró expresión diferencial del gen fadA y comportamiento distinto de componentes clave en la vía de señalización AMPc-PKA, en FS y en FL:

a. La expresión de fadA, en trofofase, fue baja en FS (excepto a las 21 h) y alta y muy intensa en FL. En idiofase fue regulada a la baja, en FS y FL.

b. En FS, se relacionó ligeramente la expresión de fadA con el nivel de AMPc (sobre todo en idiofase), encontrándose buena relación entre AMPc y PKA. Como se esperaba, hubo una relación inversa de estos componentes con la expresión de lovE y el clúster biosintético lovastatina (lovF).

c. Sin embargo, en $\mathrm{FL}$, se encontró una relación directa entre la concentración de AMPc y actividad PKA, siendo el comportamiento de ambos controversial en idiofase (niveles altos en ambos, más en AMPc) y siendo opuesto al patrón de expresión $\mathrm{fad} A$.

2. Los resultados corroboran que la vía FadA/AMPc-PKA, tiene, al menos en parte, una influencia reguladora sobre la biosíntesis de lovastatina y conidiación en Aspergillus terreus (probablemente a través de mecanismos de regulación similares a los publicados para otros hongos), pero siendo distinto el comportamiento en ambos sistemas de cultivo.

a. El patrón de expresión del gen laeA, regulador global de metabolitos secundarios, tuvo un comportamiento ligeramente similar al observado en fadA, 
con un máximo a las $21 \mathrm{~h}$ (trofofase) y regulada a la baja en idiofase. Este comportamiento fue inesperado, ya que se cree tiene un papel fundamental en idiofase en ambos sistemas de cultivo.

b. Se observaron, inesperadamente, comportamientos inversos en la expresión de los genes laeA y lovE.

c. En FS, se encontró una correlación positiva entre la actividad PKA y la expresión del gen laeA (alta en la trofofase).

d. El patrón de expresión del factor específico de conidiación brlA fue el contrario al observado en $\mathrm{fad} A$. Esto sugiere que fue regulado negativamente por FadA $(\mathrm{Ga})$. Algo similar se observó con la expresión de lovE y subsecuente del gen lov $F$, es decir, inhibe conidiación y biosíntesis de lovastatina en $A$. terreus.

3. Con relación a FS vs FL, se encontró expresión diferencial de algunos genes del clúster específico de lovastatina, esporulación y respuesta al estrés (gen laeA, lovE y lov $F$, brlA, atfB y $m s n A)$ :

a. Se observó mayor transcripción del gen laeA en trofofase (18 h en FS y $21 \mathrm{~h}$ en $\mathrm{FL}$ ) y regulada a la baja en idiofase en ambos sistemas de cultivo.

b. En FS, mayor expresión de los genes del clúster de lovastatina en idiofase (lovE y lov $F$ ), mayor expresión de brlA (prácticamente no hubo en FL), relacionado con la conidiación, mayor expresión de atfB y también una ligera mayor expresión de $m n s A$.

4. Al sobreexpresar laeA (SE::laeA) se hallaron diferencias en parámetros fisiológicos analizados y en el comportamiento de algunos componentes de la vía de señalización AMPc-PKA

a. Se confirmó que las mejores transformantes tienen integrado la construcción respectiva y se sobreexpresa el gen lae $A$, en ambos sistemas de cultivo.

b. Las mejores transformantes modificaron la expresión de algunos genes, que involucran la vía de señalización AMPc-PKA, el clúster biosintético, esporulación y respuesta al estrés ( fad $A$, laeA, lovE, lov $F$, brlA y $m n s A$ ), además de otros aspectos fisiológicos, como el crecimiento y la conidiación, siendo generalmente mayores respecto a la parental. 
c. Se concluyó que SE::laeA bajo cualquiera de las 2 estrategias usadas (con promotor constitutivo y propio promotor), son excelentes métodos para generar cepas sobreproductoras (lovastatina) en FS y, en menos abundancia, para FL.

d. El tiempo de producción fue mayor en las mejores transformantes caracterizadas: para FS (T9laeA y T2laeAcons) y para FL (T1laeA y T5laeAcons).

e. Este método de mejoramiento genético molecular ofrece alta proporción de sobreproductoras en la población de transformantes (particularmente para FS) así como altos incrementos de producción de lovastatina. En FS, la transformante con promotor constitutivo, T2laeAcons, alcanzó $30.6 \mathrm{mg} / \mathrm{gss}$ (104\% de incremento). En FL, la transformante con promotor propio, T1laeA, produjo $0.89 \mathrm{mg} / \mathrm{mL}$ (102\% de incremento).

\section{PERSPECTIVAS}

- Evaluar la expresión de los mismos genes y componentes de la vía AMPc-PKA analizados en esta tesis, así como parámetros fisiológicos, pero en mutantes de expresión constitutivamente activa de fadA ( $\left.f a d A^{\mathrm{G} 42 \mathrm{R}}\right)$. Lo anterior nos dará una visión más clara que el patrón de transcripción. Es decir, ver el efecto de activar la vía, sobre los componentes, blancos moleculares y funciones fisiológicas.

- Un complemento ideal sería generar mutantes con interrupción del gen laeA $(\Delta / a e A)$, y hacer los mismos análisis.

- Lo anterior se compararía con lo obtenido en las transformantes que SE::/aeA, para obtener una comprensión más clara de cómo son expresados o regulados dichos componentes. 


\section{BIBLIOGRAFÍA}

Acuña-Arguelles, M. E., Gutiérrez-Rojas, M., Viniegra-González, G., Favela-Torres, E. (1995). Production and properties of three pectinolytic activities produced by Aspergillus niger in submerged and solid-state fermentation. Appl Microbiol Biotechnol. 43, 808-814.

Adams, T. H., Boylan, M. T. y Timberlake, W. E. (1988). brlA is necessary and sufficient to direct conidiophore development in Aspergillus nidulans. Cell. 54(3), 353-362.

Adams, T. H., Wieser, J. K. y Yu, J. (1998). Asexual sporulation in Aspergillus nidulans. Microbiol and Mol Biol Rev. 62(1), 35-54.

Aguirre, J., Hansberg, W. y Navarro, R. (2006). Fungal responses to reactive oxygen species. Med. Mycol. 44, S101-S107.

Alwine, J. C., Kemp, D. J. y Stark, G. R. (1977). Method for detection of specific RNAs in agarose gels by transfer to diazobenzyloxymethyl-paper and hybridization with DNA probes. Proc Natl Acad Sci USA. 74(12), 5350-4.

Amaike, S. y Keller, P. N. (2009). Distinct roles of VeA and LaeA in development and pathogenesis of Aspergillus flavus. Eukaryotic Cell. 8(7), 1051-1060.

Arratia-Quijada, J., Sánchez, O., Scazzocchio, C. y Aguirre, J. (2012). FlbD, a Myb transcription factor of Aspergillus nidulans, is uniquely involved in both asexual and sexual differentiation. Eukaryotic Cell. 11, 1132-1142.

Axelrod, D. E., Gealt, M. y Pastushok, M. (1973) Gene control of developmental competence in Aspergillus nidulans. Dev Biol. 34, 9-15.

Bahn, Y. S., Xue, C., Idnurm, A., Rutherford, J. C., Heitman, J. y Cardenas, M. E. (2007). Sensing the environment: Lessons from fungi. Nat. Rev. 5, 57-69.

Balakrishnan, K. y Pandey, A. (1996). Production of biologically active secondary metabolites in solid state fermentation. J Sci Ind Res. 55, 365-372.

Banuett, F. (1998). Signalling in the yeasts: An informational cascade with links to the filamentous fungi. Microbiol. Mol. Biol. Rev. 62, 249-274.

Baños, J. G., Tomasini, A., Szakács, G. y Barrios-Gonzalez, J. (2009). High lovastatin production by Aspergillus terreus in solid-state fermentation on polyurethane foam: an artificial inert support. J. Biosci. Bioeng. 108, 105-110.

Barrios-González, Javier. (2012). Solid-state fermentation: Physiology of solid medium, its molecular basis and applications. Process Bioch. 47, 175-185.

Barrios-González, J., Baños, J. G., Covarrubias, A. A. y Garay-Arroyo, A. (2008). Lovastatin biosynthetic genes of Aspergillus terreus are differentially expressed in solid-state and in liquid submerged fermentation. Appl Microbiol Biotechnol. 79, 179-86.

Barrios-González, J., Castillo, T. E. y Mejía, A. (1993). Development of high penicillin producing strains for solid state fermentation. Biotechnol Adv. 11, 525-37.

Barrios-González, J., Fernández, F. J. y Tomasini, A. (2003). Microbial secondary metabolites production and strain improvement. Indian J of Biotechnol. 2:322-333.

Barrios-González, J., Tomasini, A., Viniegra-González, G. y López, L. (1988). Penicillin production by solid state fermentation. Biotechnol Lett. 10, 793-798.

Barrios-González, J. y Mejía, A. (1996). Production of secondary metabolites by solid-state fermentation. Biotechnol Annu Rev. 2:85-121.

Barrios-González, J. y Mejía, A. (2007). Production of antibiotics and other commercially valuable secondary metabolites. In: Pandey A., Larroche C., Soccol C. R., Rodriguez-Leon J. A. Eds. Delhi: Springer Science/Asiatech Publishers. Current Developments in Solid State Fermentation. Chapter 14: 262-296. New York/New.

Barrios-González, J. y Mejía, A. (2009). Microbial strains for the production of antibiotics and other commercially valuable secondary metabolites by solid-state fermentation. In: Pandey A., Larroche C., Soccol C. R., Dussap C. G., Eds. New horizons in biotechnology. New Delhi: Asiatech Publishers. 7688. 
Barrios-González, J. y Miranda, R. U. (2010). Biotechnological production and applications of statins. Appl Microbiol. Biotechnol. 85, 869-883.

Bayram, Ö, Braus, G. H., Fischer, R. y Rodriguez-Romero, J. (2010). Spotlight on Aspergillus nidulans photosensory systems. Fungal Genet Biol. 47, 900-908.

Bayram, Ö., Krappmann, S., Ni, M., Bok, J. W., Helmstaedt, K., Valerius, O., Braus-Stromeyer, S., Kwon, N. J., Keller, N. P., Yu, J. H. y Braus, G. H. (2008) VelB/VeA/LaeA complex coordinates light signal with fungal development and secondary metabolism. Science. 320, 1504-1506.

Bayram, Ö. y Braus, G. H. (2012). Coordination of secondary metabolism and development in fungi: the velvet family of regulatory proteins. FEMS Microbiol Rev. 36(1), 1-24.

Bencina, M., Panneman, H., Ruijter, G. J., Legisa, M. y Visser, J. (1997). Characterization and overexpression of the Aspergillus niger gene encoding the cAMP-dependent protein kinase catalytic subunit. Microbiol. 4, 1211-20.

Betina, V. (1995). Differentiation and secondary metabolism in some prokariotes and fungi. Folia Microbiol. 40(1), 51-67.

Bigelis, R., He, H., Yang, H., Chang, L. P. y Greenstein, M. (2006). Production of fungal antibiotics using polymeric solid supports in solid-state and liquid fermentation. $J$ Ind Microbiol Biotechnol. 33, 81526.

Bok, W. J., Balajee, A. S., Marr, A. K., Andes, D., Fog, N. K, Frisvad, C. J. y Keller, N. P. (2005). LaeA, a regulator of morphogenetic fungal virulence factors. Eukaryot Cell. 4. 1574-1582.

Bok, W. J., Hicks, J., Maggio-Hall, L., Noordermeer, D., Shimizu, K., Tsitsigiannis, D. I. y Keller, N. P. (2004). Protein kinase a regulation of secundary metabolism is mediated by the transcriptional regulators LaeA and AfIR. 7th European Conference on Fungal Genetics.

Bok, W. J., Noordermeer, D., Kale, S. P. y Keller, N. P. (2006). Secondary metabolic gene cluster silencing in Aspergillus nidulans. Mol Microbiol. 61, 1636-1645.

Bok, W. J. y Keller, N. P. (2004). LaeA, a regulator of secondary metabolism in Aspergillus spp. Eukaryot Cell. 3, 527-535.

Bölker, M. (1998). Sex and crime: heterotrimeric G proteins in fungal mating and pathogenesis Fungal Genet. Biol. 25,143-156.

Braus, G. H., Irniger, S. y Bayram, O. (2010) Fungal development and the COP9 signalosome. Curr Opin Microbiol. 13, 672-676.

Braus, G. H., Krappmann, S. y Eckert, S. E. (2002). Sexual development in ascomycetes - fruit body formation of Aspergillus nidulans. Mol Biol of Fungal Dev. 1, 215-244.

Brodhagen, M. y Keller, N. P. (2006). Signalling pathways connecting mycotoxin production and sporulation. Mol Plant Pathol. 7(4), 285-301.

Busch, S. y Braus, G. H. (2007). How to build a fungal fruit body: from uniform cells to specialized tissue. Mol Microbiol. 64, 873-876.

Calvo, A. M. (2008). The VeA regulatory system and its role in morphological and chemical development in fungi. Fungal Genet and Biol. 45(7), 1053-1061.

Calvo, A. M., Wilson, R. A., Bok, J. W. y Keller, N. P. (2002). Relationship between secondary metabolism and fungal development. Microbiol Mol Biol R. 66, 447-459.

Campos, C., Fernández, J. F., Sierra, C. E., Fierro, F., Garay, A. y Barrios-González, J. (2008). Improvement of penicillin yields in solid-state and submerged fermentation of Penicillium chrysogenum by amplification of the penicillin biosynthetic gene cluster. World J. Microbiol. Biotechnol. 24, 3017-3022.

Carvalho, M. D. F., Baracho, M. S. y Baracho, I. R. (2002). Investigation of the nuclei of hülle cells of Aspergillus nidulans. Genet Mol Biol. 25, 485-488.

Chan, J. K., Moore, N. R., Nakashima, T. T., y Vederas, C. J. (1983). Biosynthesis of mevinolin. Spectral assignment by double-quantum coherence NMR after high carbon-13 incorporation. J Am Chem Soc. 105, 3334-3336.

Chang, M. H., Chae, K. S., Han, D. M. y Jahng, K. Y. (2004). The GanB Ga-protein negatively regulates asexual sporulation and plays a positive role in conidial germination in Arpergillus nidulans. Genetics. 167, 1305-1315. 
Chang, P. K., Scharfenstein, L. L., Ehrlich, K. C, Wie, Q., Bhatnagar, D. and Ingber B. F. (2012). Effects of laeA deletion on Aspergillus flavus conidial development and hydrophobicity may contribute to loss of aflatoxin production. Fungal. Biol. 116, 298-307.

Chang, P. K., Scharfenstein, L. L., Luo, M., Mahoney, N., Molyneux, R. J., Yu, J., Brown, R. L. y Campbell, B. C. (2011). Loss of $m s n A$, a putative stress regulatory gene, in Aspergillus parasiticus and Aspergillus flavus increased production of conidia, aflatoxins and kojic acid. Toxins. 3, 82-104.

Chang, P. K., Scharfenstein, L. L., Mack, B. y Ehrlich, K. C. (2012). Deletion of the Aspergillus flavus orthologue of $A$. nidulans flu $G$ reduces conidiation and promotes production of sclerotia but does not abolish aflatoxin biosynthesis. Appl Environmental Microbiol. 78, 7557-7563.

Church, G. M. y Gilbert, W. (1984). Genomic sequencing. Proc Natl Acad Sci USA. 81(7), 1991-5.

Demain, A. L. y Fang, A. (2000). The natural functions of secondary metabolites. Adv Biochem Eng Biotechnol. 69, 1-39.

Derouin, F. (1994). Diagnosis, treatment and prevention of invasive aspergillosis. A priority target in hospital units. Pathologie Biologie. 42(7), 629-631.

Díaz-Gódinez, G., Soriano-Santos, J., Augur, C., Viniegra-González, G. (2001). Exopectinases produced by Aspergillus niger in solid-state and submerged fermentation: a comparative study. $J$ Ind Microbiol Biotechnol. 26, 271-5.

Dixon, D. D. y Walsh, T. J. (1992). Human pathogenesis, in Aspergillus. Biology and Industrial Application, J. W. Bennett and M. A. Klich, Eds. 249-267. Butterworth-Heinemann, Boston, Mass, USA. Døskeland, S. O., Maronde, E. and Gjersten, B. T. (1993). The genetic subtypes of cAMP-dependent protein kinase - Functionally different or redundant? Biochim Biophys Acta. 1178, 249-258.

Elinbaum, S., Ferreyra, H., Ellenrieder, G. y Cuevas, C. (2002). Production of Aspergillus terreus alpha-I-rhamnosidase by solid state fermentation. Lett Appl Microbiol. 34, 67-71.

Ellis, T. T., Reynolds, D. R. y Alexopoulos, C. J. (1973). Hülle cells development in Emericella nidulans. Mycologia. 65, 1029-1035.

Emri, T., Molnar, Z., Szilágyi, M. y. Pócsi, I. (2008). Regulation of autolysis in Aspergillus nidulans. App Bioch and Biotechnol. 151(2-3), 211-220.

Endo, A. (2004). The origin of statins. Atherosclerosis Supp. 5, 125-130.

Estruch, F.y Carlson, M. (1993). Two homologous zinc finger genes identified by multicopy suppression in a SNF1 protein quinase mutant of Saccharomyces cerevisiae. Mol Cell Biol. 13, 3872-3881.

Etxebeste, O., Herrero-García, E., Araujo-Bazán, L., et al. (2009). The bZIP-type transcription factor FlbB regulates distinct morphogenetic stages of colony formation in Aspergillus nidulans. Mol Microbiol. 73(5), 775-789.

Etxebeste, O., Ni, M., Garzia, A., et al. (2008). Basic-zipper-type transcription factor FlbB controls asexual development in Aspergillus nidulans. Eukaryotic Cell. 7(1), 38-48.

Fillinger, S., Chaveroche, M. K., Shimizu, K., Keller, N. y d'Enfert, C. (2002). cAMP and ras signalling independently control spore germination in the filamentous fungus Aspergillus nidulans. Mol Microbiol. 44(4), 1001-16.

Fox, E. M. y Howlett, B. J. (2008) Secondary metabolism: regulation and role in fungal biology. Curr. Opin. Microbiol. 11, 481-487.

Garreau, H., Hasan, R. N., Renault, G., Estruch, F., Boy-Marcotte, E. y Jacquet, M. (2000). Hyperphosphorylation of Msn2p and Msn4p in response to heat shock and the diauxic shift is inhibited by cAMP in Saccharomyces cerevisiae. Microbiology. 146, 2113-2120.

Gervais, P., Molin, P., Grajek, W., \& Bensoussan, M. (1988). Influence of the water activity of a solid substrate on the growth rate and sporogenesis of filamentous fungi. Biotechnol Bioeng. 31, 457-463.

Görner, W., Durchschlag, E., Martinez-Pastor, M. T., Estruch, F., Ammerer, G., Hamilton, B., Ruis, H. y Schüller, C. (1998). Nuclear localization of the C2H2 zinc finger protein Msn2p is regulated by stress and protein kinase A activity. Genes Dev. 12, 586-97.

Görner, W., Durchschlag, E., Wolf, J., Brown, E. L., Ammerer, G., Hamilton, B., Ruis, H. y Schüller, C. (2002). Acute glucose starvation activates the nuclear localization signal of a stress-specific yeast transcription factor. EMBO J. 21, 135-144.

Guarro, J., Gené, J. y Stchigel, A. M. (1999). Developments in fungal taxonomy. Clinical Microbiology Reviews. 12 (3), 454-500. 
Haines, J. (1995). Aspergillus in compost: straw man or fatal flaw. BioCycle. 6, 32-35.

Hang, K. H., Seo, J. A. and Yu, J. H. (2004b). Regulators of G protein-signalling in Aspergillus nidulans: RgsA downregulates stress response and stimulates asexual sporulation through attenuation of GanB (Ga) signalling. Mol Microbiol. 53, 529-540.

Harris, S. D. (2009). The Spitzenkorper: a signalling hub for the control of fungal development?. Mol Microbiol. 73, 733-736.

Hendrickson, L., Davis, R. C., Roach, C., Nguyen, K. D., Aldrich, T., McAda, C. P. y Reeves. D. C. (1999). Lovastatin biosynthesis in Aspergillus terreus: Characterization of blocked mutants, enzyme activities and a multifunctional polyketide synthase gene. Chem Biol. 6, 429-439.

Helmstaedt, K., Schwier, E. U., Christmann, M. et al. (2011). Recruitment of the inhibitor Cand1 to the cullin substrate adaptor site mediates interaction to the neddylation site. Mol Biol Cell. 22, 153-164.

Hicks, J. K., Yu, J. H., Keller, N. P. and Adams, T. H. (1997). Aspergillus sporulation and mycotoxin production both require inactivation of the FadA Ga protein-dependent signaling pathway. EMBO J. 16, 4916-4923.

Hisada, H., Hata, Y., Kawato, A., Abe, Y. y Akita, O. (2005). Cloning and expression analysis of two catalase genes from Aspergillus oryzae. J of Bioscience and Bioeng. 99(6), 562-568.

Hoff, B., Kamerewerd, J., Sigl, C., Mitterbauer, R., Zadra, I., Kürnsteiner, H. y Kück, U. (2010). Two components of a velvet-like complex control hyphal morphogenesis, conidiophore development, and penicillin biosynthesis in Penicillium chrysogenum. Eukaryot Cell. 9, 1236-1250.

Hölker, U. y Lenz, J. (2005). Solid-state fermentation is there any biotechnological advantages. Curr Opin Microbiol. 8, 301-6.

Hong, S., Roze, L. V. and Linz, J. E. (2013). Oxidative Stress-Related Transcription Factors in the Regulation of Secondary Metabolism. Toxins. 4, 683-702.

Hong, S. Y., Roze, L. V., Wee, J. y Linz, J. E. (2013). Evidence that a transcription factor regulatory network coordinates oxidative stress response and secondary metabolism in aspergilli. Microbiologyopen. 2, 144-160.

Hutchinson, C. R., Kennedy, J., Park, C., Kendrew, G., Auclair, K. y Vederas, J. C. (2000) Aspects of the biosynthesis of non-aromatic fungal polyketides by iterative polyketide synthases. Antonie van Leeuwenhoek. 78, 287-295

Ikner, A. y Shiozaki, K. (2005). Yeast signaling pathways in the oxidative stress response. Mutat. Res. 569, 13-27.

Jacquet, M., Renault, G., Lallet, S., Mey, J. y Goldbeter, A. (2003). Oscillatory nucleocytoplasmic shuttling of the general stress response transcriptional activators Msn2 and Msn4 in Saccharomyces cerevisiae. J Cell Biol. 161(3), 497-505.

Jain, S. y Keller, N. (2013). Insights to fungal biology through LaeA sleuthing. Fungal Biol Rev. 27, 5159.

Kale, S. P., Milde, L., Trapp, M. K., Frisvad, J. C., Keller, N. P. y Bok, J. W. (2008). Requirement of LaeA for secondary metabolism and sclerotial production in Aspergillus flavus. Fungal Genetics and Biology. 45(10), 1422-1429.

Kato, N., Brooks, W. y Calvo, A. M. (2003) The expression of sterigmatocystin and penicillin genes in Aspergillus nidulans is controlled by veA, a gene required for sexual development. Eukaryot Cell. 2, 1178-1186.

Keller, N. P., Turner, G. y Bennett, J. W. (2005). Fungal secondary metabolism - from biochemistry to genomics. Nat Rev Microbiol. 3(12), 937-47.

Kennedy, J., Auclair, K., Kendrew, G. S., Park, C., Vederas, C. J. y Hutchinson, R. (1999). Modulation of polyketide synthase activity by accessory proteins during lovastatin biosynthesis. Science. 284, 1368-1372.

Kim, S. S., Kim, Y. H. y Shin, K. S. (2013). The developmental regulators, FlbB and FlbE, are involved in the virulence of Aspergillus fumigatus. J of Microbiol and Biotechnol. 23, 766-770.

Knuf, C. y Nielsen, J. (2012). Aspergilli: systems biology and industrial applications. Biotechnol J. 7, 1147-1155. 
Kosalková, K., García-Estrada, C., Ullán, V. R., Godio, P. R., Feltrer, R., Teijeira, F., Mauriz, E. y Martín, J. F. (2008). The global regulator LaeA controls penicillin biosynthesis, pigmentation and sporulation, but not roquefortine $C$ synthesis in Penicillium chrysogenum. Biochimie. 91(2), 214-25.

Krijgsheld, P., Bleichrodt, R., Van Veluw, G. J., et al. (2013). Development in Aspergillus. Studies in Mycology. 74, 1-29.

Krishna, C. (2005). Solid-state fermentation systems an overview. Crit Rev Biotechnol. 25, 1-30.

Kues, U. y Fischer, R. (2006). Asexual sporulation in mycelial fungi. In the mycota: growth, differentiation and sexuality. U. Kues and R. Fischer, Eds. 1, 263-292. Springer.

Kumar, S. M., Kumar, M. P., Sarnaik, M. H. y Sadhukhan, K. A. (2000). A rapid technique for screening of lovastatin-producing strains of Aspergillus terreus by agar plug and Neurospora crassa bioassay. $J$ of Microbiol Methods. 40, 99-104.

Kurup, V. P. y Kumar, A. (1991). Immunodiagnosis of aspergillosis. Clinical Microbiol Rev. 4(4), 439456.

Kwon, N., Garzia, A., Espeso, E. A, Ugalde, U. y Yu, J. (2010). FlbC is a putative nuclear C2H2 transcription factor regulating development in Aspergillus nidulans. Mol Microbiol. 77(5), 1203-1219.

Kwon, N., Shin, K. y Yu, J. (2010). Characterization of the developmental regulator FlbE in Aspergillus fumigatus and Aspergillus nidulans. Fungal Genetic and Biol. 47(12), 981-993.

Lalli, E. y Sassone-Corsi, P. (1994). Signal transduction and gene regulation: the nuclear response to cAMP. J Biol Chem. 269, 17359-17362.

Larroche, D. (1996). Microbial growth and sporulation behavior in solid state fermentation. J Sci Ind Res. 55, 408-423.

Latgé, J. (1999). Aspergillus fumigatus and aspergillosis. Clinical Microbiol Rev. 12 (2), 310-350.

Lehka, P. K. y Lonsane, B. K. (1994). Comparative titres, location and properties of tannin acyl hydrolase produced by PKL 104 in solid-state and submerged cultures. Process Biochem. 29, 497-503. Lengeler, K. B., Davidson, R. C., D'souza, C., Harashima, T., Shen, W. C., Wang, P., Pan, X., Waugh, M. Y Heitman, J. (2000) Signal transduction cascades regulating fungal development and virulence. Microbiol Mol Biol Rev. 64(4), 746-85.

Li, S. W., Li, M., Song, H. P., Feng, J. L. y Tai, X. S. (2011). Induction of a high-yield lovastatin mutant of Aspergillus terreus by ${ }^{12} \mathrm{C}^{6+}$ heavy-ion beam irradiation and the influence of culture conditions on lovastatin production under submerged fermentation. Appl Biochem Biotechnol. 165. 913-25.

Lodeiro, S., Xiong, Q., Wilson, W. K., Ivanova, Y., Smith, M. L., May, G. S. Matsuda, S. P. (2009). Protostadienol, biosynthesis and metabolism in the pathogenic fungus Aspergillus fumigatus. Org. Lett. 11, 1241-1244.

Magnuson, J. y Lasure, L. (2004). Organic acid production by filamentous fungi. Adv in Fungal Biotechnol for Industry, Agriculture, and Medicine. J. Tkacz and L. Lange, Eds. 307-340. Kluwer Academic \& Plenum, New York, NY, USA.

Mah, J. y Yu, J. (2006). Upstream and downstream regulation of asexual development in Aspergillus fumigatus. Eukaryotic Cell. 5(10), 1585-1595.

Maldonado, M. C. y Strasser de Saad, A. M. (1998). Production of pectinesterase and polygalacturonase by Aspergillus niger in submerged and solid-state systems. $J$ Ind Microbiol Biotechnol. 20, 34-8.

Maniatis, T., Fritsch, E. F. y Sambrook, J. (1982). Molecular cloning: a laboratory manual. Cold Spring Harbor Laboratory Press, Nueva York.

Manzoni, M. y Rollini, M. (2002). Biosynthesis and biotechnological production of statins by filamentous fungi and application of these cholesterol-lowering drugs. Appl Microbiol Biotechnol. 58, 555-564.

Marchler, G., Schüller, C., Adam, G. y Ruis, H. (1993). A Saccharomyces cerevisiae UAS element controlled by protein kinase $A$ activates transcription in response to a variety of stress condition. $E M B O$ J. 12, 1997-2003.

Martinez-Pastor, M. T., Marchler, G., Schuller, C., Marchler-Bauer, A., Ruis, H. y Estruch, F. (1996). The Saccharomyces cerevisiae zinc finger proteins Msn2p and Msn4p are required for transcriptional induction through the stress response element (STRE). EMBO J. 15, 2227-2235.

Mirabito, P. M., Adams, T. H. y Timberlake, W. E. (1989). Interactions of three sequentially expressed genes control temporal and spatial specificity in Aspergillus development. Cell. 57(5), 859-868. 
Miranda, U. R., Gómez-Quiroz, E. L., Mejía, A. y Barrios-González, J. (2013). Oxidative state in idiophase links reactive oxygen species (ROS) and lovastatin biosynthesis: Differences and similarities in submerged- and solid-state fermentations. Fungal Biol. 117(2), 85-93.

Miranda, U. R., Gómez-Quiroz, E. L., Mendoza, M., Pérez-Sánchez, A., Fierro, F. y BarriosGonzález, J. (2014). Reactive oxygen species regulate lovastatin biosynthesis in Aspergillus terreus during submerged and solid-state fermentations. Fungal Biol. 118(12), 979-989.

Miranda-Labra, R., Mejía, A., Garay-Arroyo, A. y Barrios-González, J. (2007). Different expression of gene sod1 (superoxide dismutase) in $A$. terreus, during solid-state and liquid fermentations. International Workshop on Oxidative Stress. México.

Miranda-Labra, R., Fierro, F., Gómez, L. y Barrios-González, J. (2009). Un estado oxidativo intenso es necesario para la producción de lovastatina por Aspergillus terreus. XIII Congreso Nacional de Biotecnología y Bioingeniería. México.

Miskei, M., Karanyi, Z. y Pocsi, I. (2009). Annotation of stress-response proteins in the aspergilli. Fungal Genet. Biol. 46, 105-120.

Misiek, M., y Hoffmeister, D. (2007). Fungal genetics, genomics and secondary metabolites in pharmaceutical sciences. Rev Planta Med. 73, 103-115.

Mooney, J. L. y Yager, L. N. (1990) Light is required for conidiation in Aspergillus nidulans. Gene Dev. 4, 1473-1482.

Moore, R. N., Bigam, G., Chan, K. J., Hogg, M. A., Nakashima, T. T. y Vederas, C. J. (1985). Biosynthesis of the hypocholesterolemic agent mevinolin by Aspergillus terreus. Determination of the origin of carbon, hydrogen, and oxygen by 13C NMR and mass spectroscopy. J Am Chem Soc. 107, 3694-3701.

Morton, A. G. (1961). The induction of sporulation in mould fungi. Proc $R$ Soc Lond Biol Sci. 153, 548569.

Mullins, J., Harvey, R. y Seaton, A. (1976). Sources and incidence of airborne Aspergillus fumigatus (Fres). Clinical Allergy. 6(3), 209-217.

Mullins, J., Hutcheson, P. S. y Slavin, R. G. (1984). Aspergillus fumigatus spore concentration in outside air: Cardiff and St Louis compared. Clinical Allergy. 14(4), 351-354.

Mullis, K. B. y Faloona, F. A. (1987). Specific synthesis of DNA in vitro via a polymerase catalyzed chain reaction. Methods in Enzymology. 155, 335-350.

Muntanjola, C. M. y Vukic, V. V. (1972). Influence of light on hülle cell and aleuriospore formation in Aspergillus. T Brit Mycol Soc. 58, 67-72.

Ni, M. y Yu, J. H. (2007). A novel regulator couples sporogenesis and trehalose biogenesis in Aspergillus nidulans. PLoS ONE. 2(10), 970.

Oda, K., Kakizono, D., Yamada, O., lefuji, H., Akita, O. y Iwashita, K. (2006). Proteomic analysis of extracellular proteins from Aspergillus oryzae grown under submerged and solid-state culture conditions. Appl Environ Microbiol. 72, 3448-57.

Ogawa, M., Tokuoka, M., Jin, F. J., Takahashi, T. y Koyama, Y. (2010). Genetic analysis of conidiation regulatory pathways in kojimold Aspergillus oryzae. Fungal Gen and Biol. 47(1), 10-18.

Ooijkaas, L. P., Weber, F. J., Buitelaar, R. M., Tramper, J. y Rinzema A. (2000). Defined media and inert supports: their potential as solid-state fermentation production systems. Trends in Biotechnol. 18, 356-360.

Palonen, K. E., Raina, S., Brandt, A., Meriluoto, J., Keshavarz, T. y Soini, T. J. (2017). Transcriptomic Complexity of Aspergillus terreus Velvet Gene Family under the Influence of Butyrolactone I. Microorganisms. 5(12); doi:10.3390/microorganisms5010012.

Pantazopoulou, A., Lemuh, N. D., Hatzinikolaou, D. G., Drevet, C., Cecchetto, G., Scazzocchio, C. y Diallinas, G. (2007). Differential physiological and developmental expression of the UapA and AzgA purine transporters in Aspergillus nidulans. Fungal Genet Biol. 44, 627-640.

Patananan, N. A., Palmer, M. J., Garvey, S.G., Keller, N. P. y Clarke, G.S. (2013). A novel automethylation reaction in the Aspergillus nidulans LaeA protein generates S-Methylmethionine. The $J$. of Biological Chemistry. 288(20), 14032- 14045.

Park, H. S. y Yu, J. H. (2012). Genetic control of asexual sporulation in filamentous fungi. Current Opinion in Microbiol. 15, 669-677. 
Pérez, T., Mejía, A. y Barrios-González J. (2015). Amplification of laeA gene in Aspergillus terreus: A strategy to generate lovastatin-overproducing strains for solid-state fermentation. Int. J. Curr. Microbiol. App. Sci. 4(10), 537-555.

Perfect, J. R., Cox, J. M. y Lee, J. Y. (2001). The impact of culture isolation of Aspergillus species: a hospital-based survey of aspergillosis. Clinical Infectious Diseases. 33 (11), 1824-1833.

Perrin, R. M., Fedorova, N. D. y Bok, J. W. (2007). Transcriptional regulation of chemical diversity in Aspergillus fumigatus by LaeA. PLoS pathogens. 3(4), 50.

Pitt, J. I. (1994). The current role of Aspergillus and Penicillium in human and animal health. J. of Medical and Veterinary Mycology. 32, 17-32.

Pöggeler, S., Nowrousian, M. y Kück, U. (2006). Fruiting-body development in ascomycetes. The Mycota I Growth, Differentiation and Sexuality. Fischer K., Ed. 325-355. Springer-Verlag, Heidelberg.

Punt, P. J., Dingemanse, M. A., Kuyvenhoven, A., Soede, R. D. M., Pouwels, P. H. y Van den Hondel, C.A.M.J.J. (1990). Functional elements in the promoter region of the Aspergillus nidulans gpdA gene, encoding glyceraldehyde-3-phosphate dehydrogenase. Gene 93, 101-109.

Purschwitz, J., Muller, S. y Fischer, R. (2009). Mapping the interaction sites of Aspergillus nidulans phytochrome FphA with the global regulator VeA and the white collar protein LreB. Mol Genet Genomics. 281, 35-42.

Pusztahelyi, T. y Pócsi, I. (2013). Functions, cooperation, and interplays of the vegetative growth signaling pathway in the Aspergilli. J Mycol. http://dx.doi.org/10.1155/2013/832521

Ramunas, B., Haiyin, H., Hui, Y., Yang, L. C. y Greenstein, M. (2006). Production of fungal antibiotics using polymeric solid supports in solid-state and liquid fermentation. $J$ Ind Microbiol Biotechnol. 33(10), 815-826.

Reverberi, M., Gazzetti, K., Punelli, F., Scarpari, M., Zjalic, S., Ricelli, A., Fabbri, A. A., y Fanelli, C. (2012). Aoyap1 regulates OTA synthesis by controlling cell redox balance in Aspergillus ochraceus. Appl. Microbiol. Biotechnol. 95, 1293-1304.

Reverberi, M., Zjalic, S., Ricelli, A., Fabbri, A. A. y Fanelli, C. (2006). Oxidant/antioxidant balance in Aspergillus parasiticus affects aflatoxin biosynthesis. Mycotoxin Res. 22, 39-47.

Reyes-Dominguez, Y., Bok, J. W. y Berger, H. (2010). Heterochromatic marks are associated with the repression of secondary metabolism clusters in Aspergillus nidulans. Mol Microbiol. 76(6), 1376-1386.

Robinson, T., Singh, D. y Nigam, P. (2001). Solid-state fermentation a promising microbial technology for secondary metabolite production. Appl Microbiol Biotechnol 55, 284-289.

Rodriguez-Romero, J., Hedtke, M., Kastner, C., Muller, S. y Fischer, R. (2010). Fungi, hidden in soil or up in the air: light makes a difference. Annu Rev Microbiol. 64, 585-610.

Rosén, S., Yu, J. y Adams, T. H. (1999). The Aspergillus nidulans sfaD gene encodes a G protein $\beta$ subunit that is required for normal growth and repression of sporulation. The EMBO J. 18(20), 55925600.

Roze L. V., Beaudry R. M., Keller N. P. and Linz J. E. (2004). Regulation of aflatoxin synthesis by FadA/cAMP/protein kinase A signaling in Aspergillus parasiticus. Mycopathologia. 158, 219-232.

Roze, L. V., Chanda, A., Wee, J., Awad, D. y Linz, J. E. (2011). Stress-related transcription factor AtfB integrates secondary metabolism with oxidative stress response in aspergilli. J. Biol. Chem. 286, 3513735148.

Roze, L. V., Miller, M. J., Rarick, M., Mahanti, N. y Linz, J. E. (2004). A novel cAMP-response element, CRE1, modulates expression of nor-1 in Aspergillus parasiticus. J. Biol. Chem. 279, 27428-27439.

Ruger-Herreros, C., Rodríguez-Romero, J., Fernández-Barranco, R., et al. (2011). Regulation of conidiation by light in Aspergillus nidulans. Genetics. 188(4), 809-822.

Ruijter, G. J., Visser, J. y Rinzema, A. (2004). Polyol accumulation by Aspergillus oryzae at low water activity in solid-state fermentation. Microbiol. 150, 1095-101.

Saiki, R. K., Scharf, S. J., Faloona, F., Mullis, K. B., Horn, G. T., Erlich, H. A. y Arnheim, N. (1985). Enzymatic amplification of $\beta$-globin genomic sequences and restriction site analysis for diagnosis of sickle cell anemia. Science. 230, 1350-1354.

Sakamoto, K., Iwashita, K., Yamada, O., Kobayashi, K., Mizuno, A., Akita, O., Mikami, S., Shimoi, H. y Gomi, K. (2009). Aspergillus oryzae atfA controls conidial germination and stress tolerance. Fungal Genet Biol. 46, 887-897.

Tesis de Doctorado en Biotecnología 
Sambrook, J., Fritsch, E. F. \& Maniatis, T. (1989). Molecular cloning. A laboratory manual. Cold Spring Harbor Press, Nueva York.

Sanger, F., Nicklen, S. y Coulson, A. R. (1977). DNA sequencing with chain-terminating inhibitors. Proc Natl Acad Sci USA. 74(12), 5463-5467.

Sarikaya-Bayram, O., Bayram, O., Valerius, O., Park, H. S. y Irniger, S. (2010). LaeA control of velvet family regulatory proteins for light-dependent development and fungal cell-type specificity. PLOS Genet, 6, doi:10.1371/journal.pgen.1001226.

Schaffner, A. (1992). Host defense in aspergillosis. In New Strategies in Fungal Disease. J. E. Bennett, R. J. Hay, and P. K. Peterson, Eds. 98-112. Churchill Livingstone, Edinburgh, UK.

Segeth, M. P., Bonnefoy, A., Bronstrup, M., Knauf, M., Schummer, D. y Toti, L. (2003). Coinisetin a novel tetramic acid antibiotic from Conichaeta ellipsoidea. J Antibiot. 56, 114-22.

Seo, J., Han, K. y Yu, J. (2005). Multiple roles of a heterotrimeric G-protein y-subunit in governing growth and development of Aspergillus nidulans. Genetics. 171(1), 81-89.

Shaaban, M. I., Bok, J. W., Lauer, C. y Keller, N. P. (2010). Suppressor mutagenesis identifies a velvet complex remediator of Aspergillus nidulans secondary metabolism. Eukaryot Cell. 9, 1816-1824.

Shankaranand, V. S., Ramesh, M. V. y Lonsane, B. K. (1992). Idiosyncrasies of solid state fermentation system in the biosynthesis of metabolites by some bacterial and fungal cultures. Process Biochem. 27, 33-36.

Shimizu, K. y Keller, N. P. (2001). Genetic involvement of a cAMP-dependent protein kinase in a G protein signaling pathway regulating morphological and chemical transitions in Aspergillus nidulans. Genetics. 157, 591-600.

Shimizu, K., Hicks, J. K., Huang, T. P. y Keller, N. P. (2003). Pka, Ras and RGS protein interactions regulate activity if AfIR, a Zn(II)2Cys6 transcription factors in Aspergillus nidulans. Genetics. 165, 10951104.

Skromne, I., Sanchez, O. y Aguirre, J. (1995). Starvation stress modulates the expression of the Aspergillus nidulans brlA regulatory gene. Microbiol. 141(1), 21-28.

Southern, E. M. (1975). Detection of specific sequences among DNA fragments separated by gel electrophoresis. J of Mol Biol. 98(3), 509-508.

Specht, C. A., DiRusso, C. C., Novotny, C. P., y Ulrich, R. C. (1982). A method for extracting highmolecular weight deoxyribonucleic acid from fungi. Anal. Biochem. 119, 158-163.

Sreedevi, K., Rao, V. J., Narasu, L. y Mohammed, F. (2011). Strain improvement of $A$. terreus for enhanced production of lovastastin, a HMG CoA reductase inhibitor. J. Microbiol. Biotechnol. Res. 1, 96100.

Steinberg, G. (2007). Hyphal growth: a tale of motors, lipids, and the Spitzenkorper. Eukaryot Cell. 6, 351-360.

Suryanarayan, S. (2003). Current industrial practice in solid state fermentations for secondary metabolite production: the Biocon India experience. Biochem. Eng. J. 13, 189-195.

Sweeney, M. J. y Dobson, A. D. W. (1999). Molecular biology of mycotoxin biosynthesis. FEMS Microbiol Letters. 175(2), 149-163.

Szakács, G., Morovján G. y Tengerdy R. P. (1998). Production of lovastatin by a wild strain of Aspergillus terreus. Biotechnol Lett. 20(4), 411-415.

Tag, A., Hicks, J. y Garifullina, G. (2000). G-protein signalling mediates differential production of toxic secondary metabolites. Molecular Microbiol. 38(3), 658-665.

Thevelein, J. M. (1994). Signal transduction in yeast. Yeast. 10, 1753-1790.

Thomas, P. S. (1980). Hybridization of denatured RNA and small DNA fragments transferred to nitrocellulose. Proc Natl Acad Sci USA. 77(9), 5201-5.

Tice, G. y Buchanan, R. L. (1981). Regulation of aflatoxin biosynthesis: Effect of exogenously supplied cyclic nucleotides. J Food Sci. 47, 153-157.

Toda, T., Cameron, S., Sass, P., Zoller, M., Scott, J. D., McMullen, B., Hurwitz, M., Krebs, E. G. and Wigler, M. (1987b). Cloning and characterization of BCY1, a locus encoding a regulatory subunit of the cyclic AMP-dependent protein kinase in Saccharomyces cerevisiae. Mol Cell Biol. 7, 1371-1377.

Toone, W. M. y Jones, N. (1998). Stress-activated signalling pathways in yeast. Genes Cells. 3, 485498. 
Toone, W. M., Morgan, B. A. y Jones, N. (2001). Redox control of AP-1-like factors in yeast and beyond. Oncogene. 20, 2336-2346.

UAM. Procedimiento para la producción de lovastatina por fermentación sólida en soporte inerte artificial. Mex Patent. MX 256998.

Valera, H. R., Gomes, J., Lakshmi, S., Gururaja, R., Suryanarayan, S., y Kumar, D. (2005). Lovastatin production by solid state fermentation using Aspergillus flavipes. Enzyme Microb. Technol. 37, 521-526. Van den Bossche, H., MacKenzie, D. W. R. y Cauwenbergh, G. (1988). Aspergillus and Aspergillosis. Plenum Press, New York, NY, USA.

Verdoes, C. J., Punt, J. P. y Van den Hondel, J. J. C. A. M. (1995). Molecular genetic strain improvement for the overproduction of fungal proteins by filamentous fungi. Appl Microbiol Biotechnol. 43, 195-205.

Verstrepen, K. J., Reynolds, T. B. y Fink, G. R. (2004). Origins of variation in the fungal cell surface. Nat Rev Microbiol. 2, 533-540.

Vilches-Ferrón, M. A., Casas López, J. L., Sánchez-Pérez, J. A., Fernández Sevilla, J. M. y Chisti, Y. (2005). Rapid screening of Aspergillus terreus mutants for overproduction of lovastatin. World $J$. Microbiol. Biotechnol. 21, 123-125.

Walsh, D. A. y Van Patten, S. M. (1994). Multiple pathway signal transduction by the cAMP-dependent protein kinase. FASEB J. 8, 1227-1236.

Wieser, J. y Adams, T. H. (1995). flbD encodes a Myb-like DNAbinding protein that coordinates initiation of Aspergillus nidulans conidiophore development. Genes and Development. 9(4), 491-502.

Wieser, J., Lee, B. N., Fondon III, J. W. y Adams, T. H. (1994). Genetic requirements for initiating asexual development in Aspergillus nidulans. Current Genetics. 27(1), 62-69.

Xiao, P., Shin, K., Wang, T. y Yu, J. (2010). Aspergillus fumigatus flbB encodes two basic leucine zipper domain (bZIP) proteins required for proper asexual development and gliotoxin production. Eukaryotic Cell. 9(11), 1711-1723.

Yang, H. y Lucas, G. B. (1970). Effects of $\mathrm{N}_{2}-\mathrm{O}_{2}$ and $\mathrm{CO}_{2}-\mathrm{O}_{2}$ tensions on growth of fungi isolated from damaged flue-cured tobacco. Appl Microbiol. 19(2), 271-277.

Yin, W. B., Amaike, S., Wohlbach, D. J., Gasch, A. P., Chiang, Y. M., Wang, C. C., Bok, J. W., Rohlfs, M. y Keller, N. P. (2012). An Aspergillus nidulans bZIP response pathway hardwired for defensive secondary metabolism operates through aflR. Mol. Microbiol. 83, 1024-1034.

Yoshizawa, Y., Witter, J. D., Liu, Y. y Vederas, C. J. (1994). Revision of the biosynthetic origin of oxygens in mevinolin (lovastatin), a hypocholesterolemic drug from Aspergillus terreus MF 4845. J Am Chem Soc. 116, 2693-2694.

Yu, J. (2006). Heterotrimeric G protein signaling and RGSs in Aspergillus nidulans. J. of Microbiol. 44(2), 145-154.

Yu, J. H. (2010). Regulation and development of Aspergillus nidulans and Aspergillus fumigatus. Mycobiol. 38, 229-237.

Yu, J., Butchko, R. A. E., Fernandes, M., Keller, N. P., Leonard, T. J. y Adams, T. H. (1996). Conservation of structure and function of the aflatoxin regulatory gene aflR from Aspergillus nidulans and A. flavus. Current Genetics. 29(6), 549-555.

Yu, J. H., Wieser, J. and Adams, T. H. (1996b). The Aspergillus FlbA RGS domain protein antagonizes $G$ protein signaling to block proliferation and allow development. EMBO J. 15, 5184-5190.

Yu, J. H. y Keller, N. (2005) Regulation of secondary metabolism in filamentous fungi. Annu Rev Phytopathol. 43: 437-458.

Zhang, Y. Q., Wilkinson, H., Keller, N. P. y Tsitsigiannis, D. (2004). Secondary metabolite gene clusters. Handbook of Industrial Mycology, Z. An, Ed. 355-386. 

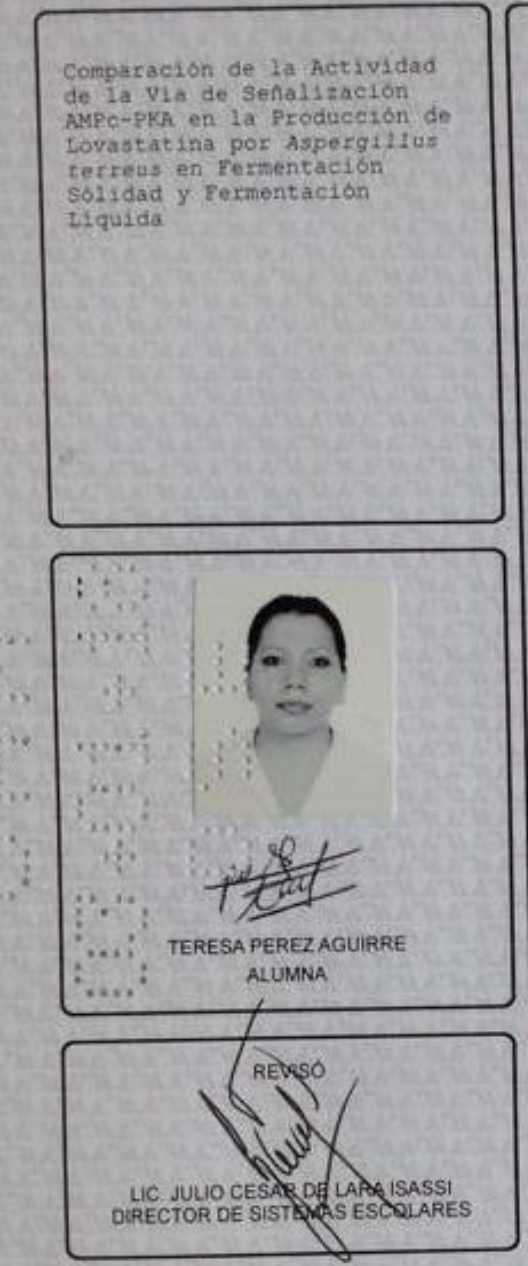

DIRECTORA DE KA DIVSION DE CBS

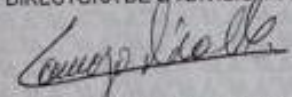

DRA SARA LUCUA CAMARGO RICALDE
En Ia Ciudad de México, se presentaron a las 13:00 horae del dia 14 del mes de díciembre del ano 2017 en la Una. Ios Iztapalapa de la Universidad

suscritos miembros del jurado:

DRA. CAPRTELA MARIALU ROORIGUE2 SBRPANO

DRA. CABRTELA MARIALTO TARRACO CASTELLLANOS

DRA. ROXAIT URT MIRANOA LAERA

DR. ARMANDO MEJIA ALVAREZ

Presianofa de la primera y con caracter de Bafo la presiaencia de la primera y presentación de la Secretario el uleimo, se reunieronación aparece al margen, para la obtención del grado de:

DOCTORA EN BLOTECNOLOGIA

DE: TERESA PEREZ AGUTRRE

y de acuerio con el articulo 78 fracción IV del Reglamento de estudios superiores de la Universidad Autónoma vetropolitans, los miembros del jurado resolvieron:

\section{ARROGAR}

Aoto continuo, la presidenta del jurado cominico a la interesada ol resultado de la eyaluación $y$, en caso aprobatorio, le fue tomada la protesta. 